\title{
LA SELECCIÓN OBJETIVA EN LA CONTRATACIÓN PÚBLICA COLOMBIANA ENTRE EL PRINCIPIO Y LA REGLA
}

\author{
MILTON JOJANI MIRANDA MEDINA \\ mjmm0414@hotmail.com
}

Tutor:

DR. GERMAN LOZANO VILLEGAS

UNIVERSIDAD SANTO TOMAS INSTITUTO DE POSTGRADOS MAESTRIA EN CONTRATACIÓN

Bogotá D.C., 2015. 
Contenido pág.

Resumen................................................................................ 4

Abstract................................................................. 5

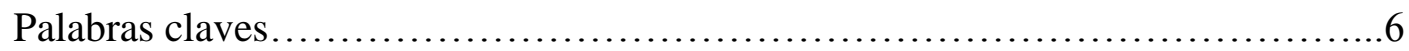

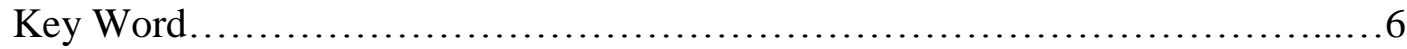

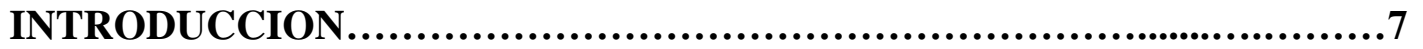

\section{Capítulo I}

APROXIMACION AL CONCEPTO DE REGLA Y PRINCIPIO..............11

1.1Antecendete del principio y de la regla ................................11

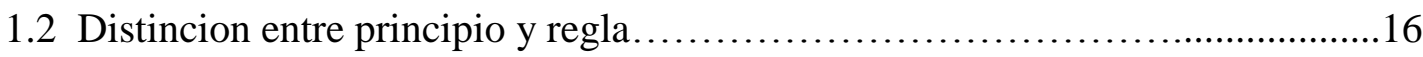

1.3 Los principios y las reglas en el marco de la Constitucion......................26

1.4 Los principios y las reglas en la Jurisprudencia...........................28

1.5Los principios y las reglas en el derecho contractual publico colombiano......41

1.6Los principios más usados en la contratacion estatal colombiana................43

\section{Capítulo II}

\section{LA REGLA O EL PRINCIPIO DE LA SELECCIÓN OBJETIVA EN LA} CONTRATACION ESTATAL EN COLOMBIA.................................51

2.1 Antecendente normativo de la Selección objetiva en la contratación Colombia....53

2.2La selección objetiva como principio de la contratacion estatal..................54

2.3La selección objetiva a la luz de la jurisprudencia..........................58 
2.4La seleccción objetiva como deber.....................................62

2.5Implicaciones de la selección objetiva en la naturaleza dual ....................71

2.5.1 La selección objetiva en el ámbito administrativo..............................71

2.5.2 La selección objetiva en el ámbito de la responsabilidad penal.................77

2.5.3 La selección objetiva en el ámbito de la responsabilidad fiscal..................78

2.5.4 La selección objetiva en el ámbito de la responsabilidad disciplinaria............79

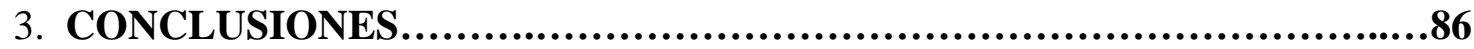

4. REFERENCIAS.............................................................90 


\section{Resumen}

En el escenario jurídico, losprincipios y las reglas, son concebidos indistintamente, como normas jurídicas constitutivas del sistema jurídico.Sin embargo, a pesar de la búsqueda de elementos diferenciadores, la doctrina y la jurisprudencia no han encontrado una distinción conceptual, que permita afirmar con meridiana claridad la contextualización de cada término, solo apuntan a señalar algunas diferencias relacionadas con la validez, el contexto de aplicación, la universalidad, la rigidez y el ámbito de responsabilidades.

No obstante, lasreglas se pueden concebir como mandatos de hacer, de permitir o de prohibir estructuradas en unos supuestos de hecho y unas consecuencias jurídicas yubicadas en el mundo del deber ser, en tanto, se debe cumplir lo estipulado en ellas. De igual forma, los principios son normas que ordenan que algo sea realizado en la mayor medida de lo posible, dentro de las posibilidades jurídicas y reales existentes, de suerte que se convierten en mandatos de optimización, que en un determinado caso pueden ser cumplidos en diferente grado.

En la legislación colombiana, la selección objetiva es tratada como principio de la contratación estatal,o como principio orientador de los procesos de selección, pero al mismo tiempo, esconcebida como un deber-regla de conducta- en la actividad contractual. Mientras que para la jurisprudencia la selección objetiva, es una regla de conducta de la actividad contractual y un principio que orienta los procesos licitatorios, que permitenla escogencia de la oferta más ventajosa para los intereses colectivos perseguidos con la contratación.

A pesar que la doctrina y la jurisprudencia aceptan indistintamente la dualidad de la selección objetiva, se considera que para pueda existir un fundamento legal, esta debe sustentarse primero, en una relación contractual y dos, en los preceptos legales. Es decir, que para poder hacer imputaciones de responsabilidad penal, fiscal o disciplinaria por la acción o la omisión del servidor público, es necesario concebir la selección objetiva como 
un mandato legal establecido para una relación contractual determinada, contrario sensu, no es posible tal imputación debido al carácter abstracto e indeterminado del principio.

\begin{abstract}
On the legal stage, principles and rules, are conceived either as constituent legal rules of the legal system. However, despite the pursuit of differentiators, doctrine and jurisprudence have not found a conceptual distinction, allowing affirming with crystal clarity the contextualization of each term, in the interpretation and application in the Contracting State, only running to point out some differences related to the validity, the application context, universality, the rigidity and the scope of responsibilities.
\end{abstract}

However, the rules are mandates do, allow, or prohibit that usually is structured by a few cases in fact and legal consequences, are the mute of the duty to be, unto the fulfilling of the content established in them. While the principles, are rules ordering that do something to the fullest extent possible, within the existing legal and real possibilities, which become in terms of optimization, which in a given case may be met in different degree.

In Colombian law, objective selection is treated as beginning of the Contracting State and conceived as duty-rules of conduct-contractual activity, as well as a guiding principle of the selection processes. While the jurisprudence for the objective selection, it is a rule of conduct of contractual activity and a principle, which guides the bidding, processes, allowing the choice of the most advantageous offer for the collective interests pursued by the recruitment.

While the doctrine and the jurisprudence accept either the duality of the objective selection, is considered that you for there is a legal basis, it should support first, in a contractual relationship, and two in the legal precepts. To make allegations of criminal, disciplinary or fiscal responsibility by action or omission of the public servant, whereas 
conceive the objective selection as a legal mandate for a particular contractual relationship, not sense, it is not possible such allocation due to the abstract and indeterminate nature of the principle.

\section{Palabras claves.}

Regla, principio, deber, selección objetiva, contratación estatal.

\section{Key Word}

Rule, principle, duty, objective selection, government contracting. 


\section{INTRODUCCION}

Con la presente investigación se pretende analizar la naturaleza de la selección objetiva en la contratación pública colombiana, a la luz de los planteamientos hechos por la doctrina y jurisprudencia,teniendo en cuenta, que el tema ha cobrado gran importancia en el debate académicos en los últimosaños, debido a que la norma contractual no hace una expresa distinción entre principio y regla, siendo aplicada con este mismo criterio, por las entidades públicas en el ámbito de la práctica contractual y en consecuencia la selección objetiva de oferentes, puede distanciarse del mandato constitucional respecto a la función administrativa.

A partir de la expedición de la constitución política de 1991, cobra relevancia el debate teórico, que se genera entorno a la aplicación de los principios y las reglas, toda vez que existe tendencias que los considera como fuentes principales del sistema jurídico y como normas de obligatorio cumplimiento que señalan deberes, mandatos, obligaciones o prohibiciones irrestrictas; dicho dilema no ha sido estudiado a profundidad, al punto que en ocasiones la doctrina y la jurisprudencia se refieren indistintamente a una y otra categoría, sin considerar las implicaciones que en algunos escenarios jurídicos, puede generar tal consideración.

En el escenario de la contratación pública colombiana, se considera que existe una serie de vacíos legales, en virtud que el legislador con fundamento en el principio de configuración legislativa, otorga ala selección objetiva una connotación dualal considerarla al mismo tiempo como principio y regla o deber, sin examinar las consecuencias que tendría en algunos contextos concretos la aplicación de la mismacategoría, o peor aún,

aplicar las consecuencias que derivan del incumplimiento de un principio o de una regla o viceversa.

Como lo ha señalado Norberto Bobbio (1987), la experiencia jurídica es en principio, una experiencia normativa, de manera que el mejor modo de aproximarse a ella 
es considerando al derecho como un conjunto o sistema de normas.Por su parte el profesor Cordero Eduardo (2009), considera que a este complejo o conjunto de normas jurídicas se le ha denominado indistintamente ordenamiento jurídico, orden jurídico y sistema jurídico. El sistema juicio colombiano se compone de una serie de disposiciones denominadas normas jurídicas, a las que se le han otorgado distintas categorías, en concordancia con su contenido, ya que unas contienen fines, otras contienen principios y otras son simples reglas, pero todas contienen el carácter imperativo, al contener deberes de obligatorio cumplimiento, lo cual hace la interpretación y la aplicación de la norma, sea una labor compleja, y más concretamente, en el estatuto de contratación estatal.

Así las cosas, esta investigación pretende hacer claridad respecto a la naturaleza de la selección objetiva en la contratación pública colombiana partiendo de la base de resolver los interrogantes que se presentan, para establecer si es un principio y o una regla. Este tipo de problemática jurídica, posibilita el acercamiento al concepto y distinción de las dos categorías a la luz de la doctrina y jurisprudencia, permitiendo de esta manera, la construcción de diferencias jurídicas teóricas y prácticas y de esta forma, retomar la discusión en torno alderecho colombiano concretamente en el derecho contractual público, para extraer los principios que orienten los procesos de selección de contratistas, sin perder de vista las diferencias teóricas extraídas del análisis realizado a cada concepto en particular.

Aunque la doctrina y la jurisprudencia se han ocupado ampliamente del tema, persiste ladificultadde entender, si la selección objetiva es un principio o un deber, o tiene una naturaleza dual para la administración ylos procesos de contratación estatal, interrogantes de los cuales se deriva la gran pregunta de esta investigación: ¿es la selección objetiva en la contratación estatal un principio general o una regla de las entidades? La respuesta a este interrogante, permitehacer un análisis de la noción de principio, regla y deber, en el escenario del derecho en general, para luego tratar de encontrar algunas diferencias y similitudes, que posibiliten la orientación de los procesos de contratación en Colombia. 
La importancia de abordar esta investigación radica entonces, enpoder encontrar una distinción conceptual de los términos principio y regla, que permita mejorar la práctica contractual del Estado, ya que tal discusión ha quedado en manos de la entidad y los funcionarios, que de una forma o de otra, tratan de interpretar y aplicar la norma, con poca objetividad jurídica, lo cual da como consecuencia la distorsión del sentido y esencia del principio y la regla, por la mixtura de categorías que se presenta, al hacer conceptualizaciones erradasque aminoran la naturaleza de la selección objetiva en la contratación estatal colombiana.

Así las cosas, el objeto de la investigación consiste en tratar de identificar si la selección objetiva es un principio de la contratación estatal o un deber que debe ser acatado porlas entidades del Estado en la escogencia de los contratistas,mediante el análisis de los planteamientos doctrinales, jurisprudencialy la evolución normativa en Colombia, con el fin de precisar el contenido de las nocionesen estudio y de esta manera,establecer las diferencias, las similitudes y losefectos jurídicos,que se derivan de considerar la selección objetiva como principio de la contratación estatal o deber de las entidades del Estado en la escogencia de contratistas.

La estrategia metodológica utilizada para desarrollar la investigación, consistió en un análisis conceptual de los planteamientos hechos por la doctrina y la jurisprudencia,abarcando el tema desde sus diferentes tópicos y concepciones, tratar de desglosar el objeto investigado en sus diferentes partes, para establecer a cuál de estas categorías verdaderamente corresponde, la selección objetiva.

El trabajo consta de dos grandes capítulos. El primero se ocupa de establecer una distinción entre principio y regla, mediante un recorrido analítico, por los planteamientos expresados por los diferentes autores estudiados y lo expuesto por la doctrina y la jurisprudencia. Posteriormente se hizo un análisis sobre la evolución que ha tenido la figura en el derecho contractual público colombiano, sintetizando la forma en que se ha venido 
creyendo y aplicando, para finalmente, hacer una aproximación a las implicaciones jurídicas que resultan al considerar la selección objetiva como principio o como deber, dejando la puerta abierta a las consecuencias que para el derecho disciplinario puede tener tal consideración.

En el segundo capítulo, se aborda el tema de la regla o el principio de la selección objetiva en la contratación pública colombiana; aterrizando las conclusiones en la evolución que ha tenido la figura en la legislación nacional, partiendo de los enfoques que le ha dado la doctrina y la jurisprudencia, desarrollando las dos facetas del concepto, es decir, la selección objetiva vista como un principio o como regla, para llegar a darle cabida a dicho concepto en los dos escenarios.

Una vez puestas en el escenario esas pequeñas consideraciones, y sin pretender agotar la discusión, se adopta una posición personal sobre el tema con argumentos, respecto a la conveniencia o inconveniencia que pueda existir, al considerar a la selección objetiva como un principio, o como una regla o deber, que deben cumplir las entidades del Estado y los servidores públicos en el trámite de los procesos de selección de contratistas vistas desde el ámbito administrativo, penal, disciplinario y fiscal.

Ahora bien, no podrían escribirse estas líneas sin anticipar al lector, el hecho de que una vez culminada la investigación, se avizorara una leve sensación que inclina la balanza hacia una posición que enseña que, la selección objetiva debe ser una regla de obligatorio cumplimiento que han de acatar todos los servidores públicos en el trámite de los procesos de selección de contratistas; y que se contrapone al hecho de considerarla un principio, por las razones y fundamentos teóricos que llevados al campo de la práctica contractual cotidiana, representarían problemas mayores frente a la responsabilidad que implica el cumplimiento o incumplimiento del precepto mencionado. 


\section{CAPITULO 1}

\section{APROXIMACION AL CONCEPTO DE PRINCIPIO Y REGLA}

En esta parte del trabajo de investigación, se busca mediante un análisis mesurado de los planteamientos hechos por la doctrina y la jurisprudencia, hacer una aproximación fáctica respecto a las diferencias y similitudes existentes entre los conceptosde principio y regla, con el fin de precisar el contenido y el sentido de cada una de estas categorías, usadas de manera habitual en el derecho moderno de la contratación estatal colombiana.

\subsection{ANTECEDENTE DEL PRINCIPIO Y LA REGLA.}

Aunque con otra terminología, en Alemania Josef Esser(1950),le dio un tratamiento profundo al tema de la distinción entre reglas y principios, desde épocas remotas que permitióempezar a entender la existencia de dos conceptos diferentes, es decir, que para esta época ya se concebía la existencia de categorías distintas de estas dos figuras jurídicas, tanto desde el punto de vista de la interpretación como de su aplicación. De igual forma, en Austria, Walter Wilburg(1950), anticipo algunas apreciaciones esenciales sobre este aspecto, en su teoría de los sistemas en movimiento, donde se planteó que teniendo en cuenta que el derecho es una ciencia dinámica y cambiante, no se puede dar una misma accesión a losmismos términos.

Para Cianciardo (2004), el cuestionamiento de la coherencia y viabilidad del positivismo se ha dado desde numerosas perspectivas, pero la que más se acerca por la forma crítica y por su idoneidad para plantear escenarios nuevos, es la jurisprudencia de los principios o constitucionalismo de los principios, que consiste en la insuficiencia que se presenta considerar que existe un universo normativo provisto únicamente por proposiciones datadas de un supuesto de hecho y una consecuencia jurídica, tesis que se defendió por el positivismo del siglo pasado y comienzo del presente. Esta teoría llegó a sostener que los principios no tenían cabida en el ordenamiento jurídico por su carácter abierto y flexible. Sin embargo, el positivismo ha sido rebatido por el 
neoconstitucionalismo que piensa junto a las normas o reglas jurídicas, existe otras con estructura diferente, con criterios dúctiles denominadas principios.

De la lectura del texto, se observa que las primeras consideraciones que se hicieron entorno alos dos términos, se dieron con preferencia a la regla sobre el principio, en el entendido que la teoría pura del derecho, que sustentaba el positivismo jurídico, primaba sobre cualquier otra interpretación, postulado propio del pensamiento de Kelsen. Así las cosas, la regla se concibe como el elemento principal, que permite que el derecho se constituya en una ciencia, dentro de la cual, no hay cabida para otro tipo de proposición, que no tengan el carácter prohibitivo o constitutivo de la regla. En estas condiciones iniciales, no era posible pensar en que el principio formara parte del cuerpo normativo existente.

Recientemente el profesor Alexy (2003), considera que el debate internacionalmás amplio sobre esta distinción se desencadeno gracias a los planteamientos de Ronald Dworkin, quien en su artículo The Model of Rules, publicado por primera vez en 1967,convirtióel tema, en el fundamento de un gran ataque contra la versión del positivismo jurídico pregonado por Hart. En las tres décadas trascurridas desde entonces, la distinción entre reglas y principios y sus implicaciones para la teoría de la aplicación jurídica, la estructura del sistemajurídico, la relación entre derecho y moral y la dogmática jurídica, en especial la dogmática de los derechos fundamentales, ha sido objeto de un insoslayable conjunto de investigaciones, algunas de ellas bien profundas. (p. 6).

De acuerdo a la teoría de Cianciardo (2004), es a partir de las nuevas tendencias constitucionales de la postguerra, que se establecen lecturas distintas respecto a la composición del contenido jurídico y se consiente pensar en el principio como parte del conjunto de proposiciones normativas a través de los cuales se podía interpretar y aplicar el derecho, en tanto, se abrendistintos horizontes hermenéuticos que orientan la actividad judicial. Este nuevo enfoque de la justicia constitucional está contenida en las corrientes neoconstitucionales surgidas como reacción ala rígida corriente positivista del derecho. 
En palabras de Domínguez (2008), se puede afirmar, que el neoconstitucionalismo es la teoría constitucional surgida en Europa después de la Segunda Guerra Mundial, cuyos postulados fueron expuestos en la Constitución Italiana (1947), la constitución Alemana (1949), la constitución portuguesa (1976) y la española (1978); en Brasil (1988) y luego, en la Constitución colombiana en1991.

Este modelo neoconstitucional surge de la integración del modelo norteamericano y el europeo. Para Prieto Sanchis (2003), el primero considera la Constitución como un juego de competencias entre lo político y lo social, dado en un contexto de igualdad entre los individuos, que desarrollan su vida dentro de un Estado neutral, mientras que el segundo, la Constitución es entendida como un proyecto político de transformación social y político, que busca acercarse a las ideas de libertad, justicia, democracia e igualdad expuestas en la Revolución Francesa.

Sin embargo, en el nuevo arquetipo constitucional dice De la Calle (1991), se exige que los sistemas del derecho constitucional interno, se transformen y se identifiquen con los paradigmas de hermenéutica jurídica internacional contenida en la Declaración Universal de los Derechos del Hombre y del catálogo de los Derechos Humanos, a través de los bloques de constitucionalidad ${ }^{1}$.

Esta teoría del derecho constitucional, describe los logros de la constitucionalización y resalta la presencia omnipresente de los principios y reglas, y las peculiaridades de la interpretación y de la aplicación de las normas, es decir, representa una

\footnotetext{
${ }^{1}$ En el caso colombiano este modelo es cabalmente acogido por la Carta en los artículos 93 y 214, donde se establece que los tratados internacionales de derechos humanos ratificados por Colombia prevalecen en el derecho interno, Artículo 93, dice: "los tratados y convenios internacionales ratificados por el congreso, que reconocen los derechos humanos y que prohíben su limitación en los estados de excepción, prevalecen en el orden interno. Los derechos y deberes consagrados en esta Carta, se interpretaran de conformidad con los tratados internacionales sobre derechos humanos ratificados por Colombia”. El artículo 214 dice: “(...) no podrán suspenderse los derechos humanos ni las libertadas fundamentales. En todo caso se respetaran las reglas del derecho internacional humanitario (...)".
} 
alternativa respecto a la teoría ju positivista tradicional, en partícula a los postulados que han sido insolutos, como el legiscentrismo y el formalismo interpretativo. (Arango, 2005, p.31).

Pese a los diversos planteamientos sobre la primacía de los derechos humanos, en la teoría noeoconstitucional, existe una verdadera dificultad para definir los derechos humanos, sin embargo, hoy es un tema recurrente para la academia. Para Pérez Luño (1999), los derechos humanos se constituyen en "el conjunto de facultades e instituciones que en cada momento histórico, concretan las exigencias de la dignidad, la libertad y la igualdad humanas, las cuales deben ser reconocidas positivamente por los ordenamientos jurídicos a nivel nacional e internacional" (p.48).

Lo que sucede es que con la Declaración Universal de los Derechos Humanos (1948), se centró el discurso político y jurídico y le dio la función de protección de los Derechos al Estado, obligándolo a prevenir, investigar y sancionar las violaciones que ocurran. En este sentido, dentro de la teoría de los Derechos Humanos, tienen particular relevancia los Derechos Fundamentales, como propiedades inherentes al ser humano. (Madrid y Melo, 1998, p.1).

Así las cosas, los Derechos Fundamentales se constituyen en el elemento principal de la estructura del Estado, de laConstitución y de los demás derechos, porque ellos hacen parte del contenido dogmático constitucional. La institucionalización de las disposiciones constitucionales atribuye a los Derechos Fundamentales, en el mundo jurídico, una existencia independiente y prioritaria sobre la moral, la sociología y el fundamentalismo político o religioso, en la medida que hacen parte de los principios, del Estado constitucional de derecho. (Alexy, 1993).

De esta forma, el Estado constitucional de derecho, pertenece al imperio de la Constitución, de los convenios y del derecho de los tratados internacionales sobre derechos humanos, de donde se deriva la verdadera justicia, toda vez que este marco de derechos 
permite dirimen todos los conflictos surgidos en la sociedad. (Cristopher Wolf, 1991, p. 284).

En este escenario de globalización de las jurisdicciones internas, la persona humana se convierte en sujeto activo de derecho internacional y se transforma el concepto de soberanía nacional, en tanto, que el principal desafío de los sistemas jurídicos actuales, lo constituye la búsqueda de la armonización de las jurisdicción interna con la jurisdicción internacional.

En el nuevo ordenamiento constitucional, se fortalece el sistema de separación de poderes públicos, se incorpora los derechos y libertades individuales no sólo como contenidos constitucionales, sino como mecanismos jurídicos de protección real de los derechos $^{2}$; además, se engrosa el marco de los derechos constitucionales, con normas como la protección al derecho al trabajo, el derecho de asociación, a la cultura y la protección de minorías, entre otros. (Carbonel Miguel, 2003, p10).

El ordenamiento jurídico colombiano vigente, se ha inclinado por la teoría neoconstitucional de acuerdo a lo preceptuado en el artículo 1 de la Constitución Política, al determinar que Colombia es un Estado Social de Derecho, fundado en el respecto a la dignidad humana, la supremacía de los principios constitucionales y la primacía de los derechos humanos, constituyéndose en un verdadero catálogo de principios, derechos y valores constitucionales, mandatarios en todas las actuaciones administrativas y judiciales que se desarrollen en el territorio nacional. (Bernal Pulido, 2008). Tendencia que ha sido ampliamente debatida por la doctrina y jurisprudencia, al punto que Corte Constitucional en sus decisiones, superpone los principios constitucionales sobre los contenidos puramente normativos.

\footnotetext{
${ }^{2}$ Como ejemplo de esto se tiene la acción de tutela, como un mecanismo judicial básico para la protección de los derechos fundamentales de los residentes en Colombia.
} 
De este nuevo enfoque constitucional, entre otros temas, surge las diversas interpretaciones entre principio y regla, en virtud de la relevancia jurídica que adquieren los primeros, para el profesor Comanducci P. (1998), la discusión en torno a los conceptos de regla y principio es materia inacabable, al considerar que en la actualidad se puede afirmar, que existe una especie de acuerdo para determinar que tanto los principios y las reglas, están consideradas por el derecho como una clase de normas.Así las cosas, para efectos de esta investigación se acogerán las consideraciones hechas por el profesor italiano, las cuales permiten poder contextualizar la discusión de reglas y principios dentro del escenario de las normas jurídicas ${ }^{3}$ y evitar dispersar la atención en otros campos que no son de interés para esta investigación, como es el caso de la teoría del neoconstitucionalismo y sus implicaciones en el Estado constitucional de derecho.

\subsection{Distinción entre principio y regla.}

Para abordar esta disertación entorno a la distinción entre principio y regla, nos atenemos a lo expuesto por la doctrina que recoge el sentir respecto a los temas, buscando encontrar lo pertinente para la investigación.Arteta L. (2011), considera que las normas jurídicas son conceptos que representan acciones humanas, donde la conducta es la realidad representada por la normas. Plantea que esa conducta así representada conceptualmente, es una manifestación del contenido de las relaciones sociales reguladas jurídicamente y que dicho contenido no existe con anterioridad a la creación y producción de las normas, contrariamente es producido por ellas, porque es requerido por los hombres que las crean, en tal sentido, al producirse una norma jurídica los hombres que la producen, representan conceptualmente la conducta humana por ella significada.

Mientras que en la Enciclopedia Jurídica de Colombia "las reglas también han sido concebidas en diferentes acepciones, así por ejemplo, una regla puede ser una fórmula que

\footnotetext{
${ }^{3}$ Para una gran mayoría de los autores, dedicados al estudio del tema, existen coincidencias al momento de reconocen que las reglas y los principios hacen parte de una categoría denominada normas jurídicas, entre los que se pueden citar a Alexy R, Prieto S, Cianciardo J, entre otros.
} 
sirva de vehículo a un principio general del derecho”. (Bohórquez B. 2008, P. 2343).En este sentido, Bohórquez B. (2008), considera que:

\begin{abstract}
Enel universo jurídico existen unos lineamientos generales o derroteros que demarcan el camino a seguir, ante las diferentes situaciones de un pueblo en un momento determinado de la historia; es así como se concibe una primera definición de lo que se conoce como los principios generales del derecho. Se podría decir que los principios generales del derecho son las direcciones o líneas matrices según las cuales se desarrollan las instituciones jurídicas. Cualquier principio de derecho supone una concepción de lo que se estima como justo formulada en una regla de derecho (P. 4798).
\end{abstract}

De la lectura de los textosexpuestos, se presume quetanto la regla como el principio constituyen un cuerpo general de derecho, necesarios para la regulación humana, donde una y otra, direccionan, regulan y desarrollan la institución jurídica. Se insinúa, que el principio puede seruna ampliación de la norma jurídica, en tanto, una regla puede ser una fórmula que sirve de vehículo a la aplicación del principio. Esto es, los principios constituyen lineamientos generales dentro de los cuales se desarrolla la norma jurídica.

Sin embargo, para otros autores los principios son concebidos como axiomas generales que siempre han existido en el derecho. A este respecto sea pronuncia el profesor Martineau F. (2009)al expresar: "los Principios generales del derecho se definen como las máximas tradicionales de efecto general. En efecto los principios generales del derecho revisten una doble característica: por un lado son como un continente y un instrumento que permite moldear un contenido jurídico”.(P. 64).

El autor se refiere a los principios rectores que anteceden una norma, en tanto estos constituyen las premisas fundamentales a tener presente en la aplicación de la norma en sí, y no al principio como axioma jurídico. El profesor Sobrevilla D. (1996), considera que en todos los sistemas jurídicos existen reglas y principios y la distinción principal entre los dos conceptos, radica básicamente en que, las reglas tiene el carácter de ser aplicables o no, en cambio los principios están sujetos a la ponderación y tienen la propiedad de peso. Por su parte, López (2012), considera que este es uno de los criterios de distinción empleado por Dworkin, al afirma que:"las reglas son aplicadas en la forma todo o nada, y por otro lado 
los principios, que resultan aplicables en los casos duros o difíciles orientanla solución del caso”.(p. 287). Bajo esta concepción, podría pensarse de manera primigenia que en la teoría de Dworkin, el principio no tiene un rol de obligatoriedad, en el sentido que lo concibe como un hecho orientador del caso sub judice, mientras que la regla debe ser aplicadas en su totalidad.

Ahora bien, algunos autores nos recuerdan que la discusión entre reglas y principios se da, en el escenario de las normas jurídicas, y mantienen diferencias especificas a cada categoría, Bernal C. (2005) expresa: "Principios y reglas son normas jurídicas que regulan la conducta humana y que se utilizan para construir y fundamental las decisiones jurisdiccionales. Sin embargo entre estos dos tipos de elementos jurídicos median considerables diferencias". (P. 572).

En estas disquisiciones, pareciera que el panorama se encuentra despejado, pues es claro que las reglas se aplican o no se aplican, mientras que el principio orienta la decisión a tomar en un determinado caso, sin embargo, hay quienes se preguntan ¿qué sucede cuando se presenta un conflicto entre principios?; pues es allí donde cobra gran importancia la otra diferencia entre principios y reglas establecida por Dworkin, y es esa propiedad o dimensión de peso que se encuentra presente en los principios y que brilla por su ausencia en las reglas; dejándose al arbitrio de quien decide el caso, la aplicación de uno u otro principio conforme a la ponderación que de cada uno de ellos se haga.

Dworkin (2007), piensa que la diferencia entre reglas y principios no está dada exclusivamente por una deferencia de grado, sino por el contrario es más conceptual. Así las cosas, la reglas son normas que reclaman un cumplimiento pleno, y en esa medida, pueden ser solo cumplidas o incumplidas, porque si una norma es válida, es entonces obligatorio hacer lo que ordena. Las reglas contienen terminaciones reales, por tanto, su aplicación no puede sustraerse de la subsunción. Por su parte los principios son normas que ordenan algo en la medida de lo posible en el escenario de los hechos, sus mandatos 
optimizan un caso real y pueden ser cumplidos en diferentes grados, y la forma de aplicación es la ponderación.

Acordado que los principiosadquierenmayor importancia, en el ámbito de cada caso en concreto,permite que algunos autores establezcan diferencias entre principios y reglas, en el escenario de la interpretación, como punto para solucionar las eventuales colisiones que puedan surgir entre una categoría y otra. Así al referirse a los principios, por ejemplo, López, Osorio, Mendoza, Jiménez, Victoria, Betancourt, Hernández, Mazabel, Carrillo y Oliveros (2010), “como es bien sabido la norma no agotan la realidad, presentándose de esta forma vacíos que el operador judicial desde su sabiduría tiene que superar recurriendo a otras herramientas jurídicas como son los principios jurídicos.

En esa inacabable discusión para identificar, diferencias o similitudes entre los principios y las reglas, hemos llegado al campo practico de la aplicación de las distintas categorías de norma, al punto que los principios cobran gran relevancia en cada caso concreto, autores como López, (2012) expresan: "En los casos difíciles el sistema jurídico carece de una solución para el caso, el juez a su vez tiene el deber de establecer la premisa jurídica en la que fundara su decisión, muchos autores de los citados consideran que en estos caso el juez acude a los principios”.

Al este respecto Prieto L. (1996), dice que: "lo que hace que una norma sea un principio o una regla no es su enunciado lingüístico, si no el modo de resolver sus eventuales conflictos: si colisionado con una determinada norma cede siempre o triunfa siempre, es que estamos ante una regla; si colisionado con otra norma cede o triunfa según los casos, es que estamos ante un principio". (p. 287).

En esta dirección, Alexy R. (2010), resalta que los principios son normas que ordenan que algo sea realizado en la mayor medida posible, dentro de las posibilidades jurídicas y reales existentes, para que de esta forma, los principios se conviertan en verdaderos mandatos de optimización; por su parte las reglas son normas que sólo pueden 
ser cumplidas o no, cuando expresa: "de ahí que se demarque una clara diferenciación entre los conceptos principio y regla,donde el primero de ellos tiende a ser más flexible en su aplicación que el segundo, pues nótese que la regla se aplica o no se aplica, en tanto que el principio en determinado momento puede ceder ante otro". (p.7).

En cambio para otros doctrinantes los principios se identifican como postulados directos de aplicación. Así por ejemplo, Atienza Manuel y Ruiz Juan (1991),consideran que:"los principios se caracterizan por que configuran de forma abierta las circunstancias que constituyen sus formas de aplicación”.(p. 168).

Partiendode la premisa de que las reglas y los principios son una clase de normas, Alexy (2010), establece criterios de distinción. Para el autor existe el criterio de la generalidad según el cual los principios son normas de grado superior y las reglas normas de grado inferior ${ }^{4}$, afirma que,"esta distinción de grado entre reglas y principios constituye la tesis de la separación débil; inclinándose por la tesis de la separación fuerte que afirma que la distinción entre reglas y principios no es solamente un problema de grados si no de tipo cualitativo; esto es, por su estructura, reglas y principios pertenecen a categorías diferentes, pues son estructuralmente distintos". (p.8).

Sin embargo, conforme a la tesis débil de la separación, Ruiz Ramón (1991), señala que lasreglas y principios guardan entre sí una relación de parecido de familia y una diferencia de grado, no cualitativa que desempeñan un papel similar o análogo en el discurso jurídico.Sostiene, que "los principios tienen una mayor generalidad que las reglas, pero por lo demás no hay especiales características para distinguirlos de ellas, si no tan sólo distintos modos de interpretarlos y aplicarlos". (p. 10).

\footnotetext{
${ }^{4}$ Para mejor compresión de los criterios de distinción entre regla y principio, se puede ver sistema jurídico, principios jurídicos y razón práctica, texto que integra la ponencia presentada por el autor en las IV jornadas internacionales de lógica e informática jurídicas celebradas en San Sebastián en Septiembre de 1988.
} 
Puedepensarse entonces, que la particularidad del peso que revisten los principios marca una gran diferencia con las reglas, pero existe otro ingrediente diferenciador que es el relativo a la validez; para voces autorizadas sobre la materia, como Prieto Luis(1996),"los principios, tienen una característica que está ausente en las normas y que es su peso o importancia y por ello cuando dos principios se interfieren y entran en conflicto siguen siendo válidos, por más que en el caso concreto se conceda preferencia a uno de ellos, lo que no ocurre con las reglas donde no podemos decir que una norma sea más importante que otra dentro del sistema y de ahí que si se da un conflicto entre dos normas una de ellas no puede ser válida”.(p. 45).

De lo expresado por el autor,puede pensarse que los principios gozan de un estatus superior o por lo menos más indeterminado que la norma, en tanto su función no se extingue por la presencia de otros principios o la intervención de la regla, porque su campo de acción vas más allá de la simple regulación normativa, por contener la denominada característica del peso o la importancia,en tanto que las reglas, contienen una orden que se aplica o no;es decir que, en el marco de un eventual conflicto entre reglas, una de ellas será válida y la otra no. Al respecto dice Esser J. (1961): "Los principios son los criterios estructuradores del sistema jurídico, su razónjurídica y también operan como guías o exigencias para los órganos creadores de Derecho" (p.18).

De igual forma, López P. (2012), cree que losprincipios así considerados, se diferencian de las reglas, pues pertenecen a una categoría aparentemente superior, que delimitan de manera amplia el camino a seguir en un determinado momento; ello se compadece con la definición positiva de principios que expuso en su momento el profesor RonalDworkin, al expresar:"el estándar que ha de ser observadoporque es una exigencia de justicia, equidad o alguna otra dimensión de la moralidad”.(p. 283).

Siendo el ámbito de las normas, donde confluyen las reglas y principios, ha de precisarse con lo esbozado, que las reglas contienen una orden que debe cumplirse sin mayores reparos, en tanto, los principios son mandatos de categoría superior, que pueden 
ser cumplidos en mayor o menor grado conforme a la aplicación práctica que se de en cada caso concreto. La base de la teoría de las reglas y principios expuesta por el profesor Alexy (2007), se sustenta precisamente en que "las reglas son normas que siempre pueden cumplirse o incumplirse, por el contrario, los principios son normas que ordenan que algo sea realizado en la mayor medida posible, de acuerdo con las posibilidades fácticas y jurídicas, en tanto, son mandatos de optimización”. (p. 350).

A su paso, hay quienes sostienen que el criterio de distinción entre reglas y principios, se establece en el antecedente de cada norma, al sostener:

Por tanto, la distinción entre reglas y principios, si se funda sobre la inaplicabilidad, noes una división entre categorías de normas con diferentes estructuras lógicas, sino, a lo sumo, una distinción empírica y una diferencia de grado, dependiendo del nivel de predominio de características que toda norma posee hasta cierto punto: sólo podemos decir que una norma es una 'regla' en la medida que su antecedente contiene términos descriptivos precisos, y que es un 'principio' en cuanto su antecedente contiene términos imprecisos o valorativos, y su prioridad es indeterminada. (Sartor, 1995, p. 144).

Del análisis de los criterios expuestos por el profesor Sartor, hay quienes a pesar de negar la existencia de tal distinción,concluyen que realmente siexistencriterios de distinción entre las categorías de regla y principio,es el caso del profesor Aarnio(2000)que expresa que:"Esto significa que las reglas y los principios pertenecen a dos categorías de normas diferentes, esto es, a la categoría de las normas de deber hacer y, respectivamente, a la de normas de deber-ser”. (p. 600).

A esta altura de la disertación, ha de considerarse entonces, que las reglas llevan implícito un deber, un mandato u orden que señala irrestrictamente el camino que debo seguir ante una determinada situación, donde no se admite si no dos posibilidades, el cumplimiento o el incumplimiento; en tanto los principios, por ser categoríasmás abiertas, abstractas e indeterminadas, queen palabras del profesor Alexy (2007),contienen un mandato que debe ser cumplido, en la mayor medida de lo posible, es decir, se admiten distintos grados de cumplimiento o incumplimiento. 
Sin embargo, para Cianciardo J. (2014), el escenario en el que es más factible encontrar la distinción entre una regla y un principio es el campo práctico de su aplicación, porque es allí donde entra en juego el criterio de validez de cada una de estas categorías,cuando manifiesta: "en los casos de conflictos entre reglas hay que decidir la precedencia de una u otra, y esa decisión conllevará la anulación de la regla preterida”.(pp. 200, 894).

Ahora bien, el criterio de validez tiene una dimensión diferente cuando se trata de solucionar una colisión entre principios, pues en ese escenario los principios siempre serán válidos, porque según el profesor Alexy (2007), el criterio a aplicar será el de peso,lo que implica una ponderación ${ }^{5}$ de principios frente a cada caso en particular, que en esencia, es lo que distingue los dos conceptos de análisis en esta investigación, ya que la ponderación, se encuentra presente en los principios y ausente en las reglas y constituye la particularidad de los planteamientos de la obra de Alexy.

Como se ve, son múltiples las definiciones y acepciones que encierra el concepto de principio, sin embargo, no se puede afirmar que cada vez que se define el alcance de dicho concepto se evidencia un común denominador, no obstante, la tendencia general, es que los principios constituyen una concepción de superioridad, de concepto jurídico indeterminado, de directriz y de relevanciadentro del sistema jurídico ${ }^{6}$. Por su parte, la regla en cierra un

\footnotetext{
${ }^{5}$ Es un método que surge de la relación directa entre moral y principios fundamentales, en tanto, estos se constituyen en principios de justicia material fundados en la moral. Decimos que es un método porque permite manejar las categorías morales que no son susceptibles de aplicar por vía de subsunción, y mantienen la pretensión de validez que no puede ser desplazada por las normas tradicionales, empleadas para la solución antinomias normativas.

${ }^{6}$ Díaz Revorio en su libro Valores Superiores e Interpretación Constitucional, se refiere a los ocho alcances que según Atienza y Ruiz Manero puede tener el concepto de principio: 1) Principio como regla muy general 2) Principio como norma redactada en términos muy vagos (concepto Jurídico indeterminado. 3) Principio como norma programática o Directriz. 4) Principio como norma que expresa los valores superiores de un ordenamiento jurídico. 5) Principio como norma especialmente importante. 6) Principio en el sentido de norma de elevada jerarquía. 7) Principio como norma dirigida a los órganos de aplicación jurídicos y que señala, con carácter general, como se debe seleccionar la norma aplicable, interpretarla. 8) Principio como regula iuris, es decir, enunciado o máxima de la ciencia jurídica de un considerable grado degeneralidad, que permite la sistematización de un ordenamiento jurídico, o de un sector del mismo, que pueden ser implícitos o explícitos.
} 
mandato cerrado de obligatorio cumplimiento, sin permitir interpretaciones que superen el ámbito del texto normativo.

Estas diferenciaciones entre principios y regla mantiene siempre el criterio de generalidad de los primeros frente a las segundas, así lo indicó en su momento el profesor Hart (1994, citado en López, 2012), al responder a sus críticos y tratando de hallar las diferencias entre uno y otro, cuando afirmó:

Hay rasgos que distinguen las normas de los principios: a) el primero de ellos es el grado, los principios son generales o no específicos, las reglas pueden ser así consideradas como especificaciones de los principios. b) El segundo es que los principios se refieren a algún propósito, fin, titulo o valorno sólo son considerados como proporcionando una explicación o razón de las reglas que especifican, si no al menos, como contribuyendo a su justificación. c) El tercero de ellos es el carácterno concluyente de los principios, en el sentido que ellos no imponen una solución si no que suministran razones para decidir en un sentido que los tribunales lo adoptan o no. (López Pablo, 2012). P.283).

Como se dijo al comienzo de esta líneas, la característica principal que comparten tanto principios como reglas, y en la que nos hemos puesto de acuerdo para efectos metodológicos en este trabajo, es que las dos categorías son normas jurídicas, es decir enunciados que ordenan, permiten o prohíben la realización de una u otra conducta en una sociedad determinada y en un tiempo determinado. Como hemos detectado hasta este momento dichas categorías presentan ciertas diferencias cuyo debate se centra en la forma de aplicación de cada una de ellas, y en a la forma de resolver colisiones entre unos y otras. Sin embargo, hay quienes consideran lo contrario, en tanto la diferencia tiene que ver con el origen de la categoría, como es el caso de Zagreblesky (1995),quien afirma que: "por lo general, las normas legislativas son reglas, mientras que las normas constitucionalessobre derechos y sobre la justicia son predominantemente, principios”. (p.109).

Por su parte el profesor, Martineau (2009) al referirse al tema de los principios ha establecido también algunas diferencias, veamos: "En efecto los principios generales el del derecho revisten una doble característica: por un lado son como un continente y un instrumento que permite moldear un contenido jurídico, es decir, otra regla de derecho que 
aplicar (...). El recurso a los principios generales del derechoautoriza así al juez ano decidir únicamente en consideración a la regla árida y rigurosa, tal y como resulta de una lectura literal de la norma, sino en función y en consideración de otros elementos más subjetivos, como la equidad. (P 64).

De todas formas, el concepto de principio jurídico puede ser usado en diversos sentidos o acepciones, que a juicio de Atienzaet al., (1991, citado en Ruiz Ramón(1991), los más significativos son los siguientes:

En el sentido de norma muy general, entendiendo por tal la que regula un caso cuyas propiedadesrelevantes son muy generales; en el de norma redactada en términos particularmente vagos,como consecuencia de la incorporación en la misma de un número de conceptos jurídicosindeterminados; en el sentido de norma programática o directriz, esto es, de norma que estipulala obligación de perseguir determinados fines; en el sentido de norma que expresa los valoressuperiores del ordenamiento jurídico; en el de una norma especialmente importante, aunquesu grado de generalidad sea relativamente bajo; en el sentido de norma de elevada jerarquía;en el sentido de norma dirigida a los órganos de aplicación jurídicos y que señala, con caráctergeneral, como se debe seleccionar la norma aplicable, interpretarla, etc.; y, en fin, en el sentidode regula iuris, esto es, de enunciado o máxima de la ciencia jurídica que permite lasistematización del ordenamiento jurídico o de un sector del mismo. (p. 3).

Atendiendo los usos lingüísticos de los juristas, Wróblewski (1989, citado en García, 1998) distinguió hasta cinco tipos distintos de principios: principios positivos, implícitos, extrasistémicos, principios-nombre y principios-construcción. En términos muy generales, los principios positivos son los formulados en disposiciones jurídicas; los implícitos, son aquellos lógicamente deducibles de los formulados en textos jurídicos y los principios extrasistémicos son aquellos que no pertenecen a ninguna de las otras clases anteriores. (p.200).

Por su parte, el profesor Alexy (2007),respecto a la distinción entre reglas y principios sostienetres tesis: La tesis de la conformidad, que concluye la inexistencia de diferencias entre las reglas y los principios. La tesis de la separación débil ${ }^{7}$ que reduce la

\footnotetext{
${ }^{7}$ Bajo esta línea encontramos a autores como, Bobio (1982), Gianformaggio (1985), Guastini (1992), Prieto (1992), Hart (1994), Comanducci (1997), Moreso (2001).
} 
discusión de entre reglas y principios a un problema de grados, desconociendo la existencia de diferencias desde el punto de vista cualitativo, pues se piensa que así como los principios pueden ser generales y vagos habrá reglas que también ostenten dichascaracterísticas. La tesis fuerte de la separación ${ }^{8}$, reconoce la existencia de diferencias cualitativas entre los conceptos reglas y principios, al punto que concluye que toda norma es un principio o es una regla de manera excluyente.

Con fundamento en las teorías expuestashasta este punto, se puede concluir que existen diferencias bien marcadas dadas por los autores entre estas dos categorías, las cuales se pueden sintetizar en: 1) el campo de aplicación y la determinación del juicio de validez,2) los casos concretos donde se apliquen, 3) el carácter rígido, particular y estático de las reglas, frente acategorías universales, móviles,versátiles, y adaptabilidad que caracteriza a los principios, el origen de la categoría (los preceptos contenidos en las leyes reciben el calificativo de reglas, mientras que los preceptos constitucionales adquieren la categoría de principio).

A manera de síntesis y con el fin de establecer una posición personal frente a los postulados teóricos desarrollados en el capítulo, se presentaran algunas ideas respecto al tema en referencia. Se considera que la teoría de los principios es opuestaal tradicional sistema de reglas, de permisos y prohibiciones, contenida en los modelos constitucionales positivistas y organicistas del Estado, en tanto, las teorías modernas como el neoconstitucionalismo, acoge la hipótesis, dónde los problemas se pueden solucionar mediante el sistema de principios.

Se considera que los aportes más significativos respecto a las reglas y los principios, se encuentran en los planteamientos deDworkyn y Alexy, quienes señalan unas importantes diferencias conceptuales en la teoría de los principios. En consecuencia, las reglas solo pueden ser cumplidas o incumplidas porque tienen un mandato expreso, mientras que los

\footnotetext{
${ }^{8}$ Autores como Ronald Dworkin, Atienza y Ruiz Manero, Robert Alexi se inclinan por esta tesis.
} 
principios no, porque solo son normas queordenan que se realice algo, en relación con las posibilidades jurídicas y fácticas de los casos en concreto.

Los principios son, por consiguiente, mandatos de optimización, que cohabitan entre sí y cuando entran en colisión con otro, no se excluyen de la vida jurídica, mientras que las reglas, si expulsan del mundo jurídico a la contraria, es por eso que el sistema de principios se constituye en una ayuda extraordinaria para la solución de las controversias jurídicas y por lo tanto, es instrumento necesario para la interpretación normativa y una herramienta indispensable para el operador judicial.

De este modo, los principios deben ser incorporados a la construcción normativa de las decisiones judiciales, con fundamento en la norma, lo cual implica, que para determinar si una restricción particular es irracional, el juez debe tener en cuenta varios principios y directrices que le permiten establecer cuál debe ser la decisión, más razonable y proporcional para el caso en concreto.

Se considera que los principios son axiomas semejantes y por lo tanto, son conceptos que en el derecho dicen lo mismo. Así las cosas, los principios hacen parte del derecho, en cuanto contribuyen en su desarrollo y en consecuencia, se pueden considerar como normas jurídicas decarácter obligatorio.Eneste sentido, los principios nos acercan a ciencias jurídicas flexibles, abiertas y justas, mientras que las reglas nos llevan a entender el derecho como una ciencia artística, técnica y rígida. Los principios pueden desempeñar un papel constitutivo del orden jurídico, mientras que las reglas, no son más que leyes reforzadas por su forma especial que están expresamente constituidas y diseñadas por el legislativo, en tanto no tienen ninguna fuerza constitutiva fuera de lo que ellas mismas dicen y significa.

Otra importante diferencia radica en el tratamiento que la ciencia del derecho concede a las reglas y los principios, porque según lo conceptuado por autores estudiados, a las reglas se les aplica el método de la interpretación jurídica para poder entender el leguaje 
del legislador, en tanto los principios, no son objeto de interpretación, porque su significado es axiomático y no hay nada que deba ser sacado a la luz, mediante el razonamiento y laargumentación.

\subsection{Los principios y las reglas en el marco delaConstitución.}

El nacimiento del Estado de derecho implicó la aparición de dos grandes principios: el de legalidad y el de responsabilidad. En este sentido, dejamos de hablar de la existencia de Estados absolutos en los cuales la vida y los bienes de las personas le pertenecían al rey, quien podía usar y abusar de ellos siempre que así lo quisiera, debido a que sus mandatoseran aplicables a todas las personas, menos a sí mismo. (Hinestrosa, 2001, pp. $58)$.

De esta forma, dice Orrego (2013), elEstado de derecho le impuso a los gobernantes, y en este sentido también, al mismo Estado, la obligación de respetar el ordenamiento jurídico, sopena de predicar de él la responsabilidad que se derivara del irrespeto ala ley. Aun así, los principios en el Estado de Derecho no iban más allá deun mero concepto de normas programáticas, que sólo tenían aplicación en la medida de la importancia que le dieran los integrantes del órganolegislativo en el momento de crear las leyes.(p. 37).

En Colombia, con la promulgación de la Constitución de 1991, y la aparición del Estado Social de Derecho,"vino lo que se ha conocido como el fenómeno de la constitucionalización del derecho, es decir, se ha convertido en exigencia que todo el ordenamiento jurídico, este regido en su interpretación y aplicación por la Constitución Política”.(SuarezTamayo, 2010. p.59).

Bajo este nuevo esquema, se considera que el ordenamiento jurídico se compone de distintas clases de normas: las normas tradicionales que equivalen a las reglas y que contienen un supuesto de hecho y una consecuencia jurídica y las normas principios, que 
difieren de los elementos que caracterizan a las reglas, donde su contenido está destinado a la realización del principio mismo,materializado en cada caso particular y concreto. En palabras del profesor Zagrebelsky (1995), distinguir entre principios y reglas significa distinguir entre constitución y ley.

En estas condiciones, la constitución Política del 1991 en elartículo 2, estableció como fines esenciales del estadogarantizar la efectividad de los principiosen especial los consagrados en la Constitución; mientras que el artículo 4 de la Carta es enfático en señalar que la Constitución es Norma de Normas y que en caso de existir una incompatibilidad entre ella y otra norma jurídica se aplicara de manera preferente las disposiciones Constitucionales, enfatizando de esta forma la existencia del principio de primacía constitucional.(Ortega, 2006).

Dentro de las consideraciones constitucionales anteriores, Suarez Tamayo(2010), dice que algunos autores consideran que la definición de derecho alude usualmente a la existencia de cuatro tipos de normas: las reglas, losderechos, los principios y losvalores; y que todos ellos, son conceptos abstractos que comparten las características de ser vinculantes para cualquier persona que desee realizar una interpretación jurídica, en tanto, contienen sus propias pautas de interpretación.(p.68).

Avanzando en el análisis del texto Superior, encontramos que elinciso segundo delartículo 230 de la Constitución, reconoce la existencia de los principios como fuente auxiliar y articuladora del sistema jurídico colombiano, al disponer que la equidad, la jurisprudencia, los principios generales del derecho y la doctrina son criterios auxiliares de la actividad judicial. (Pombo y Guerra, 1986, p.192 y ss.).

\subsection{Los principios y las reglas en la jurisprudencia colombiana.}

Retomando el escenario que se viene planteando, en torno a diferenciar las reglas de los principios en el ordenamiento jurídico colombiano, no se puede perder de vista, otro 
ingrediente diferenciador que es aquel que se encuentra delimitado, por la fuerza vinculante de la jurisprudencia, considerando que la Corte Constitucional, respecto al principio y la regla en marco de lo legal, ha hecho trascendentales aportes.

En este escenario, la Corte Constitucional con ocasión de la demanda de inconstitucionalidad contra el artículo 8 de la Ley 153 de 1887, en las consideraciones se pregunta: ¿tenían las tres últimas fuentes citadas, analogía, doctrina constitucional y las reglas generales de derecho, fuerza obligatoria? ¿La tienen aún bajo el imperio de la nueva Carta? Concluye que las tres fuentes son aplicables al sistema jurídico colombiano, pero en particular en el caso de lasreglas generales del derecho, se trata de fuentes principalísimas. (Sentencia C-083 de 1995, M.P. Carlos Gaviria Díaz).

Sobre el texto de la sentencia el profesor Jiménez William(2008), considera que del planteamiento de la Corte resulta que los principios,son "esencialmente criterios de valoración inmanentes al orden jurídico, que se caracterizan por un exceso de contenido deontológico o axiológico, que para los positivistas clásicos tienen un carácter general, constituyen las normas fundamentales del sistema, y pueden hallarse en el sistema en forma expresa, normalmente en la Constitución nacional, pero en la mayoría de los casos se encuentran no expresos en el sistema y deben ser hallados por deducción en el espíritu del sistema".(p.17).

En esta dirección el profesor Estrada Vélez (2010), hace una críticaa la sentencia referida de la siguiente manera:

Esta Sentencia es de aquellas que no cumplen con el principio de neutralidad, pluralidad y coherencia en el uso de las fuentes doctrinarias. Se emplean autores que representan líneas filosóficas y posiciones divergentes frente al tema de los principios. Concepciones iusnaturalistas, positivistas fuertes y positivistas moderadas, confluyen en esta sentencia que se constituye en una de las más importantes en materia de fuentes del derecho. La Corte Constitucional señala que los principios no son normas que pertenecen al ordenamiento y los equiparan con la equidad y el derecho natural, haciendo referencia no a principios jurídicos sino a principios morales. Concluye la Corte, en auxilio de Genaro Carrió, que los principios no son normas jurídicas, posición totalmente diferente a la posteriormente sostenida en la Sentencia C-067 de 2003 en la que se incorporan los principios al 
bloque de constitucionalidad. No existe una línea jurisprudencial definida sobre el tema de los principios en las decisiones de esa alta Corporación. (p.166).

Respecto a la crítica del profesor Vélez, estamos de acuerdo en que Colombiaen materia jurisprudencial no existe consenso, sobre la definición y el carácter de qué debe ser y qué debe contener elprincipio, por el contrario se encuentra todavía un poco disperso el concepto, hecho que dificulta la consolidación de una línea jurisprudencial sobre el tema, encontrándonos frente a tesis o enfoques diferentes.

Por un lado, encontramos las sentencia C-083 de 1995, donde la Corte Constitucional afirma el carácter extrasistémico de los principios señalando que: "El nuestro, lo autoriza a recurrir a contenidos extrasistemáticos, a los que el propio sistema refiere formalmente V.gr. el derecho natural, la equidad, los principios generales del derecho, expresiones todas que claman por una concreción material que sólo el juez puede y debe llevar a término". (Corte Constitucional, Sentencia C-083, de 1995, M.P. Carlos Gaviria Díaz).

Deotra parte, encontramos en sentencias posteriores donde la Corte Constitucional da a los principios el carácter de normas de obligatorio cumplimiento, cuando se refiere a los principios como elementos esenciales y obligatorios para garantizar el texto constitucional, entre las que podemos citar, laC-574 de 1992,la T-005 de 1995 y la C-067 de 2003. Veamos en contexto lo que expresan cada una de ellas. En la sentencia C-574, se afirma que:

Los valores y principios incluidos en el texto constitucional cumplen la función de asegurar la permanencia y obligatoriedad del contenido material de la Constitución. Aquí se refleja la voluntad constituyente de hacer obligatorio el respeto de principios considerados universales e inherentes a la persona, cuya obligatoriedad va más allá de las contingencias propias del ordenamiento jurídico nacional. (Corte Constitucional, sentencia C-574 de 1992, MP.Ciro Angarita Barón).

En un pronunciamiento posterior la Corte resalto:“(...)nobasta con que las normas se cumplan; es necesario, además, que su cumplimiento coincida con la realización de 
principios y valoresconstitucionales. (Corte Constitucional, Sentencia T-005 de 1995. M.P: Dr. Eduardo Cifuentes Muñoz).

En el año 2003, la Corteserefierealos principios como partes integrantes del bloque de constitucionalidad, en los siguientes términos:

\footnotetext{
Por (...) normas y principios que, sin aparecer formalmente en el articulado del texto constitucional, son utilizados como parámetros del control de constitucionalidad de las leyes, por cuanto han sido normativamente integrados a la Constitución, por diversas vías y por mandato de la propia Constitución. Son pues verdaderos principios y reglas de valor constitucional, esto es, son normas situadas en el nivel constitucional, a pesar de que puedan a veces contener mecanismos de reformas diversas al de las normas del articulado constitucional strictu sensu. (Sentencia C-067 de 2003. M.P.: Dr. Marco Gerardo Monroy Cabra).
}

Como se puede observar, la línea jurisprudencia trazada por la Corte, no es del todo clara, considera distintos enfoques, lo cual no permite concebirpalmariamente la noción de principio; sin embargo, para mayor claridad, se procederá hacer memoria respecto a lateoría de los principios y las reglas vista más arribayde esta forma, escudriñar el verdadero sentido de las nociones en estudio y poder materializarlasen el contexto jurídico nacional.

Después de esta digresión, se puede sintetizar que la débil tesis delos principios planteada por la Corte Constitucional en la sentenciaC-083 de 1995, queda superada con las consideraciones de hechas en lasentencia C-067 de 2003. La primera deliberaque los principios no son normas jurídicas (discusión ampliamente superada por la doctrina nacional e internacional) si no normas extrasistémicas, podría decirse morales, que se encuentran por fuera del mundo jurídico, que solo vienen a concretarse como criterios auxiliares de las normas jurídicas y que deben aplicarse en los casos difíciles, tesis que se encuentra sustentada en la ley 153, cuando señala: "Los principios del derecho natural y las reglas de la jurisprudencia servirán para ilustrar la Constitución en casos dudosos. La doctrina constitucional es, a su vez, norma para interpretar las leyes".(Artículo 4 de la ley 153 de 1887). 
Mientras que la segunda sentencia, aborda la tesis fuerte cuya tendencia, establece que los principios forman parte del universo de las normas jurídicas. Esta tendencia expone que los principios son normas jurídicas que están por encima de las demás normas del ordenamiento jurídico; priman sobre estas y son en determinado momento el argumento o razón de la decisiones de los jueces en las sentencias, porque condicionan la validez del resto de las normas;por ello, los principio así concebidos integran el bloque de constitucionalidad y son normas de aplicación directa e inmediata y al entrar en conflicto con otros principios, se debe utilizar la ponderación como mecanismo para resolverdicha colisión.En sentencia de tutela la Corte señala:

Los principios (...), consagran prescripciones jurídicas generales que suponen una delimitación política y axiológica reconocida y, en consecuencia, restringen el espacio de interpretación, lo cual hace de ellos normas de aplicación inmediata, tanto por el legislador como por el juez. (...) Su alcance normativo no consiste en la enunciación de ideales que deben guiar los destinos institucionales y sociales con el objeto de que algún día se llegue a ellos; su valor normativo debe ser entendido de tal manera que signifiquen una definición en el presente, una base [deontológico]-jurídica sin la cual cambiaría la naturaleza misma de la Constitución y por lo tanto toda la parte organizativa perdería su significado y su razón de ser. Los principios expresan normas jurídicas para el presente; son el inicio del nuevo orden. (Corte Constitucional, sentencia T- 406 de 1992. MP. Ciro Angarita Baron).

Nótese que, la Corte enfatiza en el hecho que los principios son preceptos de aplicación inmediata, y son de obligatorio cumplimiento, pero conforme a las posibilidades jurídicas y fácticas existentes, por contener prescripciones generales de inmediato cumplimiento, que en su función de normas integradoras del sistema deben ser analizadas por el juez, interprete e incluso el legislador al momento de ser aplicadas en cada caso concreto.Dice la Corte: “(...) es claro entonces que mientras una regla jurídica se somete a pautas y criterios que determinan su aplicabilidad a cada caso en concreto a partir de la pérdida de su fuerza normativa; en tratándose de los principios dicha fuerza se mantiene inalterable, independientemente de que resulten aplicables o no a un caso concreto". (Corte Constitucional, sentencia C-818 de 2005. MP. Rodrigo Escobar Gil). 
Así mismo,a propósito del ámbito conceptual de los principios, su diferencia con las reglas y la función que cumplela Corte Constitucional, señaló:

(...) La principal diferencia entre ambos tipos de normas radica en la especificidad de sus órdenes o preceptos, pues mientras los principios son típicas normas de organización, mediante los cuales se unifica o estructura cada una de las instituciones jurídicas que dan fundamento o valor al derecho, a través de la condensación de valores éticos y de justicia; las reglas constituyen normas de conducta que consagran imperativos categóricos o hipotéticos que deben ser exactamente cumplidos en cuanto a lo que ellas exigen, sin importar el ámbito fáctico o jurídico en el que se producen.

Así las cosas, mientras las reglas se limitan a exigir un comportamiento concreto y determinado, los principios trascienden a la mera descripción de una conducta prevista en un precepto jurídico, para darle valor y sentido a muchos de ellos, a través de la unificación de los distintos pilares que soportan una institución jurídica.(...)

Los principios como lo reconoce la doctrina están llamados a cumplir en el sistema normativo los siguientes papeles primordiales: (i) Sirven de base y fundamento de todo el ordenamiento jurídico; (ii) actúan como directriz hermenéutica para la aplicación de las reglas jurídicas; y finalmente, (iii) en caso de insuficiencia normativa concreta y específica, se emplean como fuente integradora del derecho. En estos términos, es indiscutible que los principios cumplen una triple función de fundamento, interpretación e integración del orden jurídico. (Corte Constitucional, sentencia C-818 de 2005. MP. Rodrigo Escobar Gil).

En esta dirección, la Corte en la sentencia citada, también acoge la tesis del juicio de ponderación, para los caso en que sea necesario resolver conflictos que se susciten entre los principios o entre principios y reglas jurídicas al considerar que se debe otorgar primacía jurídica de un principio frente a otro y en el evento que una regla entre en contradicción con la vocación normativa de un principio, sea o no de rango constitucional, pueden conducir a que la regla no pueda ser aplicada para el caso en un caso en concreto, con el fin de evitar que se dé lugar a una declaratoria de ilegalidad o inconstitucionalidad de la norma, cuando la contradicción sea clara, manifiesta e indiscutible, frente a un principio de mayor jerarquía.(Corte Constitucional, sentencia C-818 de 2005. MP.Rodrigo Escobar Gil).

De los apartes jurisprudenciales descritos, se mantiene el enfoque y las coincidencias, expuestas en esta investigación; en el sentido de señalar una clara diferencia entre los dos preceptos en estudio, cuando se advierte que las reglas son imperativos categóricos o 
hipotéticos, de obligatorio cumplimientoen la función contractual; pues se exige un comportamiento jurídico concreto e inalterable que debe ser seguido por los funcionarios de la administración. Por su parte, los principios, si bien mantienen un carácter de

obligatoriedad en su aplicación, por ser la base o fundamento del ordenamiento jurídico, actúan como una directriz para la aplicación de las reglas imperativas y concretas que se condensan en el ordenamiento normativo y en caso de insuficiencia normativa cumplen su función integradora del sistema.

\subsection{Los principios y las reglas en derecho contractual público colombiano.}

Ya en el campo la actuación administrativa del Estado colombiano, específicamente hablando de la contratación estatal, dicha actividad se encuentra delimitada por los principios generales que rigen la función administrativa.En este escenario, se tienen los principios constitucionales consagrados en el artículo 209 Constitucional, los cuales se constituyen en mandatos de carácter superior que deben ser observado en todo el trámite de los procesos contractuales. De igual forma, existen los principios legales consagrados en la ley 80 de 1993, la ley 1150 de 2007 y los decretos reglamentarios, donde se señala de manera específica los principios que rigen la actividad contractual del Estado, su interpretación y forma de aplicación. (Santofimio, 1980, p. 317).

En esta dirección, es claro que en la actividad contractual colombiana confluyen reglas y principios, como categorías de normas jurídicas distintas que deben ser tenidas en cuenta por las entidades estatales en el trámite de los diferentes procesos contractuales. Hay quienes, con base en la jurisprudencia de la Corte Constitucional sostiene que existen dos clases de principios: "los que sin aparecer formalmente en el articulado del texto constitucional, son verdaderos principios de valor constitucional, es decir son normas situadas en el nivel constitucional (ellos son principios constitucionales explícitamente positivos), los cuales gozan del mismo status normativo de los principios que si aparecen formalmente en el articulado del texto constitucional (ellos son los principios constitucionales explícitamente positivos)".(Conrrado Roque, 2012, p. 24). 
Más adelante Conrrado (2012), dice que: "parafraseando a Valencia Restrepo, se puede llegar a una propuesta de definición según la cual los principios contractuales también son normas jurídicas, fundamentales, imperativas, universales, tópicas, axiológicas e implícitas o explícitamente positivas, que sirven para crear, interpretar e integrar el ordenamiento". (p. 24).

Ahora bien, al hacer un recorrido por la ley 80 de 1993 encontramos que desde el artículo primero que se refiere al objeto de dicha ley, se aborda el tema de las categorías que hemos tratado de diferenciar en este trabajo, cuando se resalta que el objeto de dicha ley es disponer las reglas y principios que rigen los contratos de las entidades estatales.

A su turno, el artículo 23 se refiere de manera literal a los principios de las actuaciones contractuales, señalando enfáticamente que quienes intervengan en la contratación estatal deben hacerlo con arreglo a los principios de trasparencia, economía y responsabilidad y de conformidad con los postulados que rigen la función administrativa del Estado, es decir que siendo la contratación estatal una función administrativa debe ceñirse a los principios señalados en constitucional, al predicarse en la citada norma: "Igualmente se aplicarán en las mismas las normas que regulan la conducta de los servidores públicos, las reglas de interpretación de la contratación, los principios generales del derecho y los particulares del derecho administrativo". (Constitución Política, artículo 209).

Nótese, que en el texto relativo a los principios que rigen la actividad contractual del Estado, noelevó a la categoría de principio la selección objetiva; sin embargo, la doctrina al referirse a los principios en la contratación estatal colombiana señala que estascategorías son las que inspiran toda la regulación, aun cuando no se encuentren expresadas en forma legal. Ahora bien, debe resaltarse que la ley 80 de 1993, ha regulado de manera expresa tres principios que rigen la contratación estatal, a saber: 
El principio de trasparencia, el de la economía y el de la responsabilidad y aun que no le da el nombre de principio, consagra la ecuación económica contractual (artículo 27). Igualmente el artículo 28 al hablar de interpretación de las reglas contractuales, dispone que en ella se tengan en consideración los fines y los principios de que trata dicha ley, pero además los mandatos de buena fe, igualdad y equilibrio entre las prestaciones y derechos que caracterizan a los contratos conmutativos.(Palacio Juan, 2014, p. 60).

Según el Estatuto Contractual, los principios rectores que informan y determinan la actividad relacionada con el proceso contractual de las personas que directa o indirectamente intervienen en el, son los de trasparencia, economía y responsabilidad, pero "también se deben observar los postulados que rigen la función administrativa, las normas que regulan la conducta de los servidores públicos, las reglas de interpretación de la contratación, los principios generales del derecho y los particulares del derecho administrativo".(Yong, 2013, p. 42).

Dentro del planteamiento de Yong, se observa que el derecho contractual, está cimentado en una serie de principios y reglas constitutivos de la función administrativa. Por su parte Suarez (2014), considera que entendiendo que la actividad contractual, de cualquier entidad del Estado apunta a satisfacer cometidos propios del interés público, "es entendible que el artículo 13 de la ley 1150 de 2007 haya buscado enmarcar el desarrollo en unos principios normativos que aseguren su correcto desarrollo. En este sentido los principios tienen una doble connotación, axiológica y normativa a la vez".(p. 456).

En esta misma dirección, Matallana (2013), expresa que uno de los principios orientadores del Estado Social de Derecho, se encuentra en la prestación de un servicio público eficaz, porque el artículo 209 dela Constitución establece presupuestos que guían a los servidores públicos, dentro de la función administrativa, "que le indica a las entidades estatales que están al servicio de los intereses generales y deben desarrollar sus funciones con fundamento en los principios de igualdad, moralidad, eficacia, economía, celeridad, imparcialidad y publicidad".(p.70). 
Apunta el autor a señalar que los principios orientadores de la contratación estatal, son los señalados en la Norma Superior, para el desempeño de la función administrativa del Estado y consiste en el servicio eficaz de los funcionarios públicos. Corresponde el planteamiento con lo señalado por el profesor Yong, al coincidir que el derecho contractual, está cimentado en principios y reglas constitutivos de la función administrativa y con Suarez cuando afirma que la actividad contractual, debe apuntar a satisfacer el interés público.

No obstante lo señalado, para Dávila (2003, citado en Matallana, 2013), hay que distinguir entre principios y las simples reglas o disposiciones, pues la ley 80 es una ley de principios, a diferencia del decreto 222 de 1983 que era un cuerpo de reglas. La regla es aquella proposición que tiene por objeto describir una acción u omisión, por lo cual su redacción es concreta e impersonal y el intérprete no tiene que emitir ningún juicio de valor, sino simplemente verificar si el caso concreto encaja o no en la tipificación, lo que se traduce en que la regla no puede ser aplicable por extensión. Los principios son criterios que permiten adoptar una posición específica ante una determinada situación, provocando su aceptación o rechazo; "son fruto del consenso de una comunidad respecto de unos valores que ella defiende, lo que tiene como consecuencia que algunos comportamientos se admitan y otros se rechacen".(p.318).

Más adelante Yong (2013), expresa que para la Corte Constitucional, de acuerdo a las consideraciones hechas en la sentencia C-892 de 2001, el régimen jurídico de los contratos estatales se encuentra integrado en los siguientes principios:

(i) el principio de autonomía de la voluntad, en virtud del cual la Administraciónpúblicaestá en capacidad de celebrar todos los contratos que resulten necesarios para satisfacer los intereses de la comunidad; (ii) el principio de la prevalencia del interéspúblico, que le reconoce a la administración una prerrogativa especial para ajustar el objeto del contrato a las necesidades variables de la comunidad; (iii) el principio de la reciprocidad de las prestaciones, según el cual, lo importante y relevante en el régimen de la contratación es la equivalencia real y objetiva entre los derechos y las obligaciones que surgen de la relación contractual, y no la mera equivalencia formal y subjetiva con la que se lleva a la siempre satisfacción de los intereses individuales considerados por las partes cuando se formalizo el contrato; y, finalmente, (iv) el principio de buena fe, que obliga a la 
Administración Publica y a los particulares contratistas a tener en cuenta las exigencias éticas que emergen de la mutua confianza en el proceso de celebración, ejecución y liquidación de los contratos. (p. 58).

Una aproximación muy pretenciosa al significado general de lo que, se entiende por cada uno de estos conceptos expuestos por la Corte Constitucional, se encuentra desarrollada por Suarez Tamayo (2010), sin embargo, solo se hará referencia, a lo que expreso respecto de la categoría de principios y reglas, por ser de interés para este trabajo. Señala Tamayo una importante diferencia entre los conceptos llevados al escenario del deber moral y el deber legal.

Sobre el particular señaloque los principios son “estándares generales de obligatorio cumplimiento por ser al mismo tiempo exigencia de un deber moral y presupuestos fundantes de la organización estatal. Guían al interprete en la tarea de hallar y aplicar el derecho, pese a que no aseguran una interpretación unívoca”, mientras que las reglas son “instrucciones de conducta con carácter obligatorio validado según las pautas de producción normativa, reconocidas en el ordenamiento jurídico. Contienen juicio de valor pre-establecido, por lo que se consideran encargadas de regular exclusivamente aspectos concretos de la vida social”.(p. 70).

En la aproximación traída a colación por el autor, se recoge básicamente la intención que sobre el particular quiso trasmitir el Consejo de Estado en la sentenciadel 3 de diciembre de 2007, expedientes acumulados: 25206, 25409, 24524, 27834, 25410, 26105, 28244, 31447, C.P.: Ruth Stella Correa Palacio, al determinar que:

Como atrás se señaló, la Ley 80 de 1993 contiene en forma sistematizada y ordenada las reglas y principios básicos que deben encaminar la realización y ejecución de todo contrato que celebre el Estado y, en rigor, a los cuales se encuentran sujetos los procesos de selección que adelanten las entidades públicas cuando deseen contratar bien bajo la modalidad de la licitación pública o mediante la contratación directa.

Los principios y las reglas son normas jurídicas, pues unos y otras establecen un deber ser y, finalmente, exigen un determinado comportamiento. En efecto, los principios jurídicos, como las 
reglas, tienen valor de fuente del derecho, forman parte del ordenamiento jurídico y su violación puede ser sancionada 9 .

Sin embargo, difieren en que, en tanto las reglas prescriben y exigen determinada conducta de acción u omisión, tendientes a permitir, mandar o prohibir, los principios son los valores de la sociedad transformados por el derecho en criterios o parámetros de conducta fundamentales que instruyen y rigen las relaciones jurídicas en el Estado, pues a la vez que inspiran las reglas de conducta, también se proyectan en el ordenamiento jurídico para irradiar e impregnar esos axiomas, patrones, modelos o arquetipos de comportamiento ético, cultural o social a las situaciones generales e individuales; y mientras en las reglas el juicio de valor ya se encuentra establecido al consagrar la proposición en que ella consiste, en los principios, sea que se contemplen o no en normas positivas, corresponde al intérprete realizar ese juicio a través de una operación intelectiva acerca de la coincidencia de una situación concreta con el valor correspondiente, para determinar su observancia ${ }^{10}$.

Además, los principios funcionalmente son soporte estructural del sistema, puesto que establecen los criterios esenciales que animan el ordenamiento en una determinada situación o relación que interesa al derecho, se convierten en pautas hermenéuticas para desentrañar el significado y alcance de las reglas jurídicas ${ }^{11}$, y constituyen fuente formal para resolver situaciones o problemas concretos ante la falta o insuficiencia de reglas jurídicas ${ }^{12}$.

\section{Con lo expuesto respecto al principio y la regla en el derecho contractual} colombiano, debe rescatarse que la categoría de principio y regla ha tenido una amplia discusión e incidencia en el ordenamiento jurídico colombiano, y para el caso particular en lo que tiene que ver con el régimen contractual de las entidades estatales; ahora bien, dichos

${ }^{9}$ Rivero expreso que los principios generales tienen pleno valor de Derecho Positivo, considerándoles éste como parte integrante esencial del orden jurídico y sancionando su violación con la misma energía que la de la regla escrita'. Por consiguiente, su valor es indiscutible, hayan logrado o no el reconocimiento jurisprudencial.

${ }^{10}$ Así pues, la distinción esencial parece ser la siguiente: las reglas nos proporcionan el criterio de nuestras acciones, nos dicen cómo debemos, no debemos, podemos actuar en determinadas situaciones específicas previstas por las reglas mismas; los principios, directamente, no nos dicen nada al respecto, pero nos proporcionan criterios para tomar posición ante situaciones concretas pero que a priori aparecen indeterminadas. Los principios generan actitudes favorables o contrarias, de adhesión y apoyo o de disenso y repulsa hacía todo lo que puede estar implicado en su salvaguarda en cada caso concreto. Puesto que carecen de un 'supuesto de hecho' a los principios, a diferencia de lo que sucede con las reglas, sólo se les puede dar algún significado operativo haciéndoles 'reaccionar' ante algún caso concreto. Su significado no puede determinarse en abstracto, sino sólo en los casos concretos, y sólo en los casos concretos se puede entender su alcance.

${ }^{11}$ Si los principios constituyen la base misma del Ordenamiento, nada más lógico que acudir a ellos en la laboral de interpretación de cada una de las normas que integran el ordenamiento. Ellos indicarán en cada momento la fórmula interpretativa que se debe elegir.

${ }^{12}$ El artículo 230 de la C.P. señala que los principios generales del derecho son criterio auxiliar de la actividad judicial; y el artículo 8 de la Ley 153 de 1887, señala que cuando haya ley exactamente aplicable al caso controvertido, se aplicarán las leyes que regulan casos o materias semejantes $\mathrm{y}$, en su defecto, la doctrina constitucional y las reglas o principios generales de derecho. 
preceptos o categorías mantienen esas características diferenciadoras que se han tratado de enmarcar en el curso de estas líneas, y es el hecho de ver a los principios como el precepto orientador del sistema, que puede ser aplicado en la mayor medida de lo posible de acuerdo a las posibilidades fácticas y jurídicas existentes; en tanto, que la regla mantiene la particularidad de contener mandatos imperativos que se aplican o no se aplican con la correspondiente consecuencia jurídica.

En el contexto de este panorama, no es descabellado pensar que en materia de aplicación de reglas y principios en la Contratación Estatal, se mantiene vigente la tesis señalada por el profesor Alexy (2007), en el sentido de indicar que los principios son mandatos de optimización que deben ser aplicados en la mayor medida de lo posible conforme las posibilidades fácticas y jurídicas existentes; en tanto que las reglas prescriben una conducta imperativa y concreta que se cumple o no se cumple.

Esos criterios orientadores de la actividad contractual del Estado colombiano,como son todos aquellos principios que rigen las actuaciones administrativas, sin duda, se encuentran en la normatividad aplicable al derecho público y especial. De esta forma, se puede resumir que entre los principios aplicables a la contratación estatal colombiana, están los principios de igualdad, moralidad, eficacia, economía, celeridad, imparcialidad y publicidad, consagrados en el artículo 209 de la Constitución Política y los transparencia, economía y responsabilidad, señalados en el artículo 23 de la ley 80 de 1993. Por su parte, la ley 1150 de 2007siguiendo la línea que la contratación estatal constituye una verdadera función administrativa del Estado, replica en el artículo 13 que las entidades en desarrollo la actividad contractual, deben aplicar los principios de la función administrativa y de la gestión fiscal, de que tratan los artículos 209 y 267 de la Constitución, el evento que las entidades cuenten con un régimen contractual excepcional al del estatuto general de contratación.

A su turno, Munar Lucelly y Ortiz Luis(2014), consideran que la ley 1437 de 2011 enuncia los principios que deben orientar las actuaciones y procedimientos administrativos 
que deben guiar las actuaciones contractuales, en tanto, "esta nueva legislación, mantiene el concepto de principios orientadores del proceso administrativo, como aquellos lineamientos de carácter jurídico que guían la interpretación e incluso la actuación y participación, tanto de las autoridades como de los asociados, en los procesos tendientes a la producción de un acto administrativo".(p.20). Mientras para Martínez Paola (2014), el artículo 3 de la citada norma, precisa que:"las actuaciones administrativas se desarrollaran especialmente con arreglo a los principios del debido proceso, igualdad, imparcialidad, buena fe, moralidad, participación, responsabilidad, trasparencia, publicidad, coordinación, eficacia, economía, celeridad, dando de cada uno de ellos una aplicación que busca servir de orientación para todas las personas que acudan a la administración y para los propios servidores públicos".(p.19).

Así las cosas, la doctrina establece que en Colombia, los principios básicos de la contratación estatal son:la Legalidad, la igualdad, la libre concurrencia, la buena fe, la imparcialidad, la trasparencia, la responsabilidad, la selección objetiva, la libertad de empresa, el debido proceso, la planeación, la contradicción, la prevalencia del interés general, la participación,el control ciudadano, la equidad y valoración de costos ambientales.(Suarez Tamayo, 2010, p.79).

Con este esbozado, queda claro que existen unos principios que son aplicables a la contratación pública del Estado, que de manera general son los que orientan la actividad administrativa del Estado y están contenidos en el artículo 209 de la Carta y el artículo 23 de la ley 80, sin embargo, en esa lista taxativa, no se incluyó a la selección objetivacomo principio, por el contrario dicho precepto, fue consagrado en el artículo 29 de la ley 80 con la denominación de deber y repicado en el artículo 5 de la ley 1150, de modo que de manera apresurada podría pensar que al menos, por la literalidad y contenido de dicho precepto el legislador lo concibió como una regla que debe ser aplicada por las entidades del Estado, en el trámitede las actuaciones contractuales y no como un principio orientador del sistema. 
De otro lado, hay quienes pensarían que la discusión en la práctica no tiene ningún sentido, ¿para qué determinar desde el punto de vista conceptual si un precepto como la selección objetiva constituye un principio o una regla?; aunque dicho tema será desarrollado de manera más amplia en el siguiente capítulo, desde ya se adelanta que el clasificarlo en una $\mathrm{u}$ otra categoría, le asigna consecuencias totalmente distintas, al analizarse la conducta desde el punto de vista del derecho disciplinario vigente.

\subsection{Los principios más usados en la contratación estatal en Colombia.}

El panorama de los principios en la contratación estatal, conforme a lo que hemos expuesto hasta ahora, tiene su desarrollo en diferentes fuentes normativas, como son la Constitución, la ley 80 de 1993, la ley 489 de 1998, la ley 1150 de 2007 y la ley 1437 de 2007; en su alcance y contenido han sido desarrollados, por diferentes fallos de la Corte Constitucional y del Consejo de Estado.

Sin extendernos pretender en el análisis de cada norma yprincipio en particular, a continuación se presenta un listado de los veintitrés principios generales que orientan el ejercicio de la función administrativa contractual del Estado en la actualidad, no sin antes advertir, que el de la selección objetiva, se encuentra incluido en dicho listado pero que será materia de análisis particular en el segundo capítulo de esta investigación, veamos:

1. Principio de Igualdad. ${ }^{13}$ Es fundamental que los oferentes que concurren a la licitación pública tengan igualdad de posibilidades, en la adjudicación del objeto del futuro contrato. La igualdad exige que todos los licitadores u oferentes se encuentren en la misma

\footnotetext{
${ }^{13}$ Este precepto tiene su fuente en la constitución, la ley y la jurisprudencia y aparece conceptuado en el Preámbulo y los artículos 13 y 209 de la Carta Política; en el artículo 3 Ley 489 de 1998; en el número 5 del artículo 24 y artículo 30 Ley 80 de 1993; el artículo 10 Ley 1150 de 2007; el artículo 3 Ley 1437de 2011. También fue objeto de un tratamiento especial por parte de la Sección Tercera del Consejo de Estado, en la sentencia 21 de mayo de 2008 Radicación: 660001-23-31-000-1995-03254-02(15963) M.P. Ramiro Saavedra Becerra.
} 
situación, contando con las mismas facilidades y haciendo sus ofertas sobre bases idénticas.(Dromi Roberto 2010, Pag XXXII).

2.Principio deMoralidad. ${ }^{14} \mathrm{El}$ concepto de moralidad administrativa, como principio de la actividad de la administración pública, retoma el problema clásico de moral y derecho $\mathrm{y}$, en consecuencia plantea la inquietud de efectividad del mismo, en ese sentido ha sostenido la Corte Constitucional que la moralidad constitucional de la función pública hace referencia al comportamiento del servidor público respetuoso de las formalidades y finalidades del bloque de legalidad y de los parámetros que se avienen de los principios, valores y normas de nuestro ordenamiento jurídico. (Santofimio Jaime, 1998.Pag 38)

3. Principio de Eficacia ${ }^{15}$.La esencia del principio de eficacia es el logro de las finalidades de los procedimientos administrativos, para dar prevalencia a lo sustancial sobre lo formal, su aplicación en la contratación estatal está determinada por las finalidades que el Estatuto de contratación pública atribuyo a esta modalidad de gestión pública. (Benavides José. 2014. Pag 214)

4. Principio de Economía ${ }^{16}$.En palabras del profesor Atehortúa, hace referencia a la correcta y eficiente asignación de los recursos humanos y materiales destinados para

\footnotetext{
${ }^{14}$ Tiene sustento normativo en la Constitución, en los artículos 209 C.P. En la ley, artículos 3 y 4 de la Ley 489 de 1998; artículos 8 y 9 de la Ley 80/93; artículo 40 de la ley 472/98; artículo 13 de la Ley 1150; artículo 3 de la Ley 1437/11; artículo 3 del decreto 019 de 2012. Es tratado ampliamente por la Sección Tercera del Consejo de Estado, en la sentencias del 13 de Agosto de 2008. Radicado 25000-23-27-000-2004-00888-01 (AP), M.P. Ruth Stella Correa Palacio y Radicado 54001-23-31-000-2004-01415-01(AP) del 21 de Mayo de 2008, M.P. Ramiro Saavedra Becerra y Radicado 44001-23-31-000-2003-00090-01 (AP) M.P. German Rodríguez Villamizar.

${ }^{15}$ Tiene el fundamento legal, en el artículo 209 de la C.P.; en la ley, artículo 3 de la Ley 489/98 y artículo 3 de la Ley 1437/11; en la Sentencia Consejo de Estado Sección Tercera: Radicado 25000-23-26-000-199107664-01 (14287) del 31 de agosto de 2006; M.P. Mauricio Fajardo Gómez.

${ }^{16}$ Este precepto tiene su fuente en la constitución, en artículo 209 de la C.P.; artículo 25 de la Ley 80/93; artículo 13 de la Ley 1150/11; artículo 3 de la Ley 489/98 y artículo 3 de la Ley 1437/11; en las Sentencias de la Sección Tercera del Consejo de Estado: Radicado 25000-23-27-000-2004-00888-01 (AP) del 13 de Agosto de 2008, M.P. Ruth Stella Correa Palacio. Radicado 70001-23-31-000-1997-06303-01 (23003) del 30 de julio de 2008; M.P. Mauricio Fajardo Gómez y Radicado 52001-23-31-000-199607894-01(15469) M.P. Mauricio Fajardo Gómez.
} 
ejecutar una adecuada labor o para el cumplimiento de los objetivos y metas propuestas; Al, paso que, se cumple con este principio cuando se da cumplimiento a los fines buscados, con los menores costos posibles en la producción del servicio. (Atehortúa, Carlos, 2010.Pag 522)

5. Principio de Celeridad ${ }^{17}$. Hace alusión a la agilidad de la gestión administrativa (Castro Cuenca, Carlos Guillermo, García López, Luisa Fernanda y Martínez Vargas, Juan Ramón, 2010 pág. 108.) Para la satisfacción del interés general, eliminando todos los trámites innecesarios y obstáculos que se presenten en la actuación administrativa contractual del Estado.

6. Principio de Imparcialidad.Este precepto tiene su fuente en artículo 209 de la Constitución; elartículos 3 y 4 de la Ley 489/98; artículos 8 y 9 de la Ley 80/93; artículo 13 de la Ley 1150 yartículo 3 de la Ley 1437/11. En la sentencia del 13 de agosto de 2008 del Consejo de Estado, Sección Tercera: Radicado 25000-23-27-000-2004-00888-01 (AP), M.P. Ruth Stella Correa Palacio.

7. Principio de Publicidad $^{18}$. Es un valor instrumental, íntimamente ligado al valor de la trasparencia (Habermas Jurgen, 2003.Pag 107). De modo que se busca poner en conocimiento de todas las personas, las actuaciones administrativas contractuales.

\footnotetext{
${ }^{17}$ Tiene sustento normativo en la Constitución, la ley y la jurisprudencia, en el 209 de la Constitución; artículo 3 de la Ley 489/98 y artículo 3 de la Ley 1437/11; en la Sentencia del 13 de agosto de 2008 de la Sección Tercera del Consejo de Estado: Radicado 25000-23-27-000-2004-00888-01 (AP), M.P. Ruth Stella Correa Palacio.

18 Tiene el fundamento legal, en los artículos 23, 74 y 209 de la Constitución; el artículo3 de la Ley 489/98; artículos, 22 y 41, número 6; artículo 24 número 3 y artículo 30 de la Ley 80/93; artículo 13 de la Ley 1150; artículo 3 de la Ley 1437/11; artículo 89 de la Ley 1474/11; artículo 218 del decreto 019 de 2012 y artículo 19 del decreto 1510 de 2013. En la Sentencias del 4 de septiembre de 2008 del Consejo de Estado, Sección Cuarta. Radicado 11001-03-27-000-2005-00055-00 (15739). M.P. María Inés Ortiz Barbosa y Sección Tercera, del 8 de marzo de 2007. Radicado 85001-23-31-000-1999-00500-01(16228) Mauricio Fajardo Gómez.
} 
8. Principio de Transparencia ${ }^{19}$. El principio de la transparencia en la Contratación, lo entendemos en tanto los procedimientos de selección del contratista deben estar definidos a priori, en forma precisa cierta y concreta, de modo que la administración no pueda obviar las reglas predefinidas en la norma jurídica que determina el marco de acción de la administración. (Campillo, Carlos. 2004.Pag 121)

9. Principio de Responsabilidad ${ }^{20}$. Conforme a este principio las entidades contratantes responderán patrimonialmente por las actuaciones, abstenciones, hechos y omisiones antijurídicos que les sean imputables y que causen perjuicios a sus contratistas. (Yong Samuel. 2013.Pag 52).

10. Principio del Debido Proceso ${ }^{21}$.Teniendo en cuenta que la actividad contractual, es una verdadera actuación administrativa, este principio, propende por la garantía y cumplimiento de los demás principios y garantiza a los interesados que la actuación contractual estará siempre ajustada a los justos requisitos y condiciones establecidos en la ley.

\footnotetext{
${ }^{19}$ Tiene el fundamento legal, en los artículos 1, 13, 209 y 270 de la Constitución; el artículos 3 de la Ley 489/98; artículos 23, 24, 30 y 66 de la Ley 80/93; artículo 2 de la Ley 1150; artículo 3 de la Ley 1437/11; artículos 83 y 94 de la Ley 1474/11 y artículo 3 del decreto 019 de 2012. Sentencias del 29 de agosto de 2007 del Consejo de Estado, Sección Tercera. Radicado 52001-23-31-000-1996-07894-01(15469); M.P. Mauricio Fajardo Gómez y Radicado 25000-23-26-000-1995-00787-01 (16209) del 3 de mayo de 2007, M.P. Ramiro Saavedra Becerra.

${ }^{20}$ Este precepto tiene su fuente en la constitución, la ley y la jurisprudencia y aparece conceptuado en los artículos 6, 90, 92, 95, 122 y 123 de la C.P.; el artículos 26, 50 y 56 de la Ley 80/93; artículo 48 número 29 a 34 de la ley 734/02; artículo 2 de la Ley 1150/07; artículos 3 de la Ley 1437/11 y artículo 82 de la Ley 1474/11. Sentencias del 28 de enero de 2009 del Consejo de Estado, Sección Tercera. Radicado 11001-03-26000-2007-00046-01(34239) M.P. Mauricio Fajardo Gómez; Radicado 52001-23-31-000-1996-0789401(15469) del 29 de agosto de 2007; M.P. Mauricio Fajardo Gómez y Radicado 68001-23-15-000199500782-01 (15342). M.P Ramiro Saavedra Becerra.

${ }^{21}$ Este precepto tiene su fuente en el artículo 29 de la Constitución; artículos 14 a 19 de la Ley 80/93 números 2, 3 y 8; artículo 24 de la Ley 80/93; artículo 17 de la Ley 1150/07 y artículo 3 de la Ley 1437/11. Sentencias de 13 de noviembre de 2008 del Consejo de Estado, Sección Tercera. Radicado 68001-23-31-000-199602081-01 (17009). M.P. Enrique Gil Botero y Radicado 68001-23-31-000-1997-03637-01 (16041) de 26 de Abril de 2006. M.P. Ruth Stella Correa Palacio.
} 
11. Principio de la Buena $\mathrm{Fe}^{22}$. Es un principio cardinal que se fige por los códigos de lealtad (hacia la otra parte y hacia terceros) y fidelidad, con comportamientos mutuos de coherencia, sobre la base de compromisos de cooperación y colaboración. (Dromi Roberto. 2010.Pag XXXIV)

12. Principio de Legalidad $^{23}$. Se somete la administración a la normatividad jurídica, ósea a las leyes que regulan su actividad (Betancur Carlos, 2013.Pag 34). De modo que todas las actuaciones de los intervinientes en la contratación deben estar ajustadas a la normatividad sobre la materia.

13. Principio de Libre Concurrencia ${ }^{24}$.El procedimiento de la contratación tiene que posibilitar la concurrencia, entendida como la libre posibilidad de participar en la selección del contratista (Dromi Roberto. 2010.Pag XXXVI)

14. Principio de Selección Objetiva ${ }^{25}$.La objetividad tiene por objeto asegurar la igualdad de oportunidades y a selección del oferente más solvente y capaz. (Castro Cuenca,

${ }^{22}$ Tiene el fundamento legal, en el artículo 83 de la Constitución; artículo 1603 del C.C.; artículo 835, 863, 871 del C.Co.; artículo 3 de la Ley 489/98; artículos 5, 23, 24, 26, 28, 30 Ley 80/93 y artículo 3 de la Ley 1437/11. Sentencias del 13 de agosto de 2008 del Consejo de Estado, Sección Tercera: Radicado 680123-15-000-1995-00782-01 (15342); M.P. Ramiro Saavedra Becerra y Radicado 70001-23-31-000-199706303-01 (23003) del 30 de Julio de 2008, M.P. Mauricio Fajardo Gómez.

\footnotetext{
${ }^{23}$ Este precepto tiene su fuente en el artículo 4, 12, 122 de la Constitución; artículo 13, 24, 32, 40 de la Ley 80/93; artículo 5 de la Ley 1150/07 y artículo 3 de la Ley 1437/11. Sentencias del 13 de noviembre de 2008 del Consejo de Estado, Sección Tercera. Radicado 68001-23-31-000-1996-02881-01 (17009) M.P. Enrique Gil Botero; Radicado 70001-23-31-000-1997-06303-01 (23003) del 30 de Julio de 2008, M.P. Mauricio Fajardo Gómez y Radicado 52001-23-31-000-1996-07894-01(15469) del 29 de agosto de 2007; M.P. Mauricio Fajardo Gómez.

${ }^{24}$ Tiene el fundamento legal, en el artículo 13, 333 y 334 C.P.; artículo 30 y 24 de la Ley 80/93 y artículo 5 de la Ley 1150/07. Sentencias del 4 de septiembre de 2008 del Consejo de Estado, Sección Cuarta. Radicado 11001-03-27-000-2005-00055-00 (15739). M.P. María Inés Ortiz Barbosa; Sentencias del 26 de abril de 2006, del Consejo de Estado, Sección Tercera. Radicado 73001-23-31-000-1997-04707-02 (15188) M.P María Elena Giraldo Gómez y Radicado 11001-03-26-000-1996-3771-01(12037) del 19 de Julio de 2001, M.P. Allier Eduardo Hernández Enríquez.

${ }^{25}$ Este precepto tiene su fuente en la constitución, la ley y la jurisprudencia y aparece conceptuado en el artículo 6, 121, 124 C.P.; artículo 24, 29 y de la 30 Ley 80/93 y artículo 5 de la Ley 1150/07; Sentencias Auto del 1 de Abril de 2009 del Consejo de Estado. Radicado11001-03-26-000-2009-00024-00(36476) M.P. Ruth Stella Correa Palacio. Sentencia del 3 de mayo de 2007 Radicado25000-23-26-000-1995-00787-01 (16209) M.P Ramiro Saavedra Becerra; Sentencia del 26 de Abril de 2006, Radicado 73001-23-31-000-1997-
} 
“et all”, 2010 pág. 150.)La doctrina y la jurisprudencia han sosteniendo la dualidad del presupuesto, la selección objetiva como principio y como deber regla, por su parte el profesor EXPÓSITOVELEZ consideran que es un deber, pues si se tratara de un principio, no seríauna obligación y admitiría un cumplimiento gradual realizándose en la mayor medida de lo posible.

15. Principiode Planeación ${ }^{26}$.El Consejo de Estado ha dicho que los contratos del Estado "deben siempre corresponder a negocios debidamente diseñados, pensados, conforme a las necesidades y prioridades que demanda el interés público; en otras palabras, el ordenamiento jurídico busca que el contrato estatal no sea el producto de la improvisación ni de la mediocridad ${ }^{27}$,

16. Principio de Prevalencia del interés general ${ }^{28}$.Este principio, enseña que las actuaciones administrativas contractuales, debe estar guiadas hacia el cumplimiento de los fines y cometidos estatales, manteniendo la continua y eficiente prestación de los servicios a cargo del mismo, para garantizar efectivamente los derechos de los administrados y lograr la satisfacción de las necesidades de la comunidad en general.

04707-02 (15188) M.P. María Elena Giraldo Gómez. Sentencia del 26 de abril de 2006, Radicado 66001-2331-000-1997-03637-01(16041) M.P. Ruth Stella Correa Palacio; Sentencia del 3 de diciembre de 2007, expedientes acumulados: (25206, 25409, 24524, 27834, 25410, 26105, 28244, 31447), C.P.: Ruth Stella Correa Palacio y Sentencia 10 de Marzo de 2006, Radicado 25000-23-26-000-2003-01195-01(AP) M.P Ramiro Saavedra Becerra.

${ }^{26}$ Se conceptúa en el artículo 339, 344, 345, 354 de la Constitución; artículo 25,26, 27, 41 de la Ley 80/93; Ley 152 de 1994; Ley 38/89, Ley 179/95; ley 225/95, Decreto Ley 111/96 y artículo 23 de la Ley 1150/07. Sentencias del 29 de agosto de 2007 del Consejo de Estado. Radicado 52001-23-31-000-199607894-01(15469); M.P. Mauricio Fajardo Gómez y Radicado 70001-23-31-000-1997-06303-01 (23003) del 30 de julio de 2008; M.P. Mauricio Fajardo Gómez.

${ }^{27}$ Consejo de Estado Radicación: 68001-23-15-000-1998-01743-01(27315) MP Jaime Orlando Santofimio Gamboa del 24 de abril de2013.

${ }^{28}$ Se encuentra referido en el Preámbulo y los artículos 51, 58, 62, 82, 95,133, 209, 333, 355, 366, de la Constitución y los artículos 3, 14 al 19 y 42 de la Ley 80/93. En la Corte Constitucional, Sentencia C-400 de 1999 de la. M.P. Vladimiro Naranjo Mesa. Sentencia C-128 de 2003, M.P. Álvaro Tafur Galvis. C-053 de 2001 Cristina Pardo Schlesiger y sentencia del Consejo de Estado de la Sección Tercera, del 16 de marzo de 2005. M.P. Ruth Stella Correa Palacio. Radicado 23-26-000-2002-01216-01 (27921). 
17. Principio de Participación y Control Ciudadano ${ }^{29}$.Persigue un incremento histórico cuantitativo y cualitativo de las oportunidades de los ciudadanos de tomar parte en los asuntos que comprometen los intereses generales ${ }^{30}$. Se pretende acercar a los ciudadanos al estado, permitiendo su participación, vigilancia y fiscalización de las actuaciones y recursos.

18. Principio de Equidad ${ }^{31}$. En palabras del profesor Atehortua, lo que se pretende con su aplicación es la adecuada distribución de los recursos estatales, de modo que se beneficie el mayor número posible de administrados.

19. Principio de Valoración de Costos Ambientales ${ }^{32}$. Este principio del control fiscal tiende a buscar que tanto las empresas estatales como los particulares que administran recursos del estado, tengan en cuenta el deterioro ambiental que se genera en la contratación que realizan y tomen todas las medidas conducentes a disminuir el impacto ambiental y a mitigar el impacto que se genera (Atehortúa, Carlos, 2010,Pag 527)

\footnotetext{
${ }^{29}$ Este precepto tiene su fuente en la constitución, la ley y la jurisprudencia y aparece conceptuado en el Preámbulo y los artículos 1, 2, 40, 92, 95, 103, 270, 340, 369, C.P.; artículos 5, 29,30, 66,67 de la Ley 80/93 y Ley 850 de 2003. Corte Constitucional, sentencias C-0011 de 2000 M.P. Cristina Pardo Schlesiger; sentencia C-041 de 2004, M.P María Clara Vargas Hernández y sentencia C-103 de 1996, M.P. Fabio Morón Díaz.

${ }^{30}$ Ver Sentencia Corte Constitucional C-1338-00 M.P Cristina Pardo S

${ }^{31}$ Se refiere a él la Constitución en los artículos 20, 95, 116, 226, 227, 230; artículo 3 de la Ley 80/93. En las sentencias Corte Constitucional T-1046 de 2007, M.P. Jaime Córdova Triviño; sentencias T-518 de 1998 , M.P. Eduardo Cifuentes Muñoz; y sentencias SU837 de 2002, M.P. Manuel José Cepeda Espinosa

${ }^{32}$ Este precepto tiene su fuente en la constitución, la ley y la jurisprudencia y aparece conceptuado en los artículos 8, 49, 58, 79, 80, 88 y 267 C.P.; los artículos 24, 25, 26 de la Ley 80/93 y ley 99 de 1993. Las sentencias de la Corte Constitucional C-495 de 1996, M.P. Fabio Morón Díaz; C-535 de 1996. M.P. Alejandro Martínez Caballero y C-293 de 2002, M.P. Alfredo Beltrán Sierra.
} 
20. Principio de Equilibrio Económico ${ }^{33}$.Consiste en que las prestaciones que las partes pactan de acuerdo con las condiciones tomadas en consideración, al momento de presentar la propuesta o celebrar el contrato, deben permanecer equivalentes hasta la terminación del mismo, de tal manera que si se rompe esa equivalencia, nace para el afectado el derecho a una compensación pecuniaria que la restablezca.(Rodríguez Libardo, 2009, Pag, 13)

21. Principio de la Autonomía de la Voluntad ${ }^{34}$.El artículo 40 de la ley 80 establece que las estipulaciones de los contratos serán las que se acuerdo con las normas civiles, comerciales y las previstas en esta ley, correspondan a su esencia y su naturaleza. Dada la autonomía de que Gozan para incluir todas las clausulas y modalidades contractuales que consideren necesarias para el logro de los fines contractuales (Benavides, 2007, pag, 182)

22. Principio de Reciprocidad de las Prestaciones ${ }^{35}$.El principio de reciprocidad de prestaciones encuentra su fuente de inspiración en los contratos que la doctrina suele definir como sinalagmáticos o bilaterales, caracterizados por prever el surgimiento de prestaciones mutuas o correlativas a cargo de los sujetos que integran la relación jurídico negocial. Bajo este criterio, y por efecto directo del sinalagma, las partes quedan obligadas recíprocamente a cumplir los compromisos surgidos del contrato, los cuales se estiman como equivalentes

\footnotetext{
${ }^{33}$ Este precepto tiene su fuente en la constitución, la ley y la jurisprudencia y aparece conceptuado en los números 8 y 9 del artículo 4; número 1 del artículo 5 y artículos, 27 y 28 de la Ley 80/93 y ley 99 de 1993. Las sentencias Consejo de Estado sección tercera del 2 de febrero de 1996 expediente. 8.385; y Sentencia del 24 de octubre de 1994 expediente. 11.632 y Sentencia Corte Constitucional C-892 de 2001.
}

${ }^{34}$ Este precepto tiene su fuente en la constitución, la ley y la jurisprudencia y aparece conceptuado en el artículo 16 y 1602 del Código Civil, Parágrafo 9; artículo 32 y artículo 40 ley 80/1993. Sentencia Consejo de Estado Radicación: 23001-23-31-000-1997-08763-01(17552) del 22 de Julio de 2009 Ruth Stella Correa Palacio M.P. Sentencia Consejo de Estado Radicación: 23001-23-31-000-2000-02857-01(24697) del 24 de octubre de 2013. MP Enrique Gil Botero.

\footnotetext{
${ }^{35}$ Este precepto tiene su fuente en la constitución, la ley y la jurisprudencia y aparece conceptuado en el número 8 y 9 del artículo 4; número1 del artículo 5 y artículos 27 y 28 de la Ley 80/93 y ley 99 de 1993. Las sentencias Consejo de Estado sección tercera del 2 de febrero de 1996 expediente. 8.385; y Sentencia del 24 de octubre de 1994 expediente. 11.632. Sentencia de la Corte Constitucional C-892 de 2001.
} 
y que pueden llegar a concretarse en una contraprestación, en un valor recíproco, en un acontecimiento previsible o en una cooperación asociativa.

23. Principio de Coordinación ${ }^{36}$.Conforme al cual las autoridades deben concertar sus actividades, con las de otras instancias estatales en el cumplimiento de sus cometidos y el reconocimiento de sus derechos a los particulares. (Martínez, Paola 2014, Pag 24)

Una vez enunciados de manera general los principios que orientan la función administrativa contractual del Estado en Colombia, debe rescatarse que, en esencia dicha categoría de principio, se ha venido manejando de forma reiterada,en la doctrina y en la Jurisprudencia,con un enfoque y una función dual, es decir, son considerados como el fundamento del ordenamiento jurídico y al mismo tiempo, los orientadores del sistema.Sobreel particular, ha de resaltarse lo anunciado por el profesor Tamayo (2010), refiriéndose a los principios que orientan la contratación estatal, cuando expresa:

Dicho de otra forma, ellos tienen un carácter "principalista" que condensa la esencia política y moral del ordenamiento jurídico que encabezan y, por tanto, otorgan validez y legitimidad tanto a interpretaciones jurídicas como a las mismas reglas o creaciones normativas (leyes, decretos, contratos etc.). Como están enunciados de forma abstracta en textos legales y jurisprudencia constitucional y administrativa, permiten su constante actualización y garantizan el contacto de la Constitución con la historia y las personas, sin que lo anterior implique sacrificar la seguridad jurídica a la hora de hallar y aplicar el derecho (su estructura abierta pero objetiva, aunque no asegura una interpretación univoca, los convierte en la guía por excelencia de la interpretación jurídica). (p.78).

De la anterior descripción, se observa que el régimen de contratación estatal en Colombia, esta soportado por un amplio cuerpo de principios normativos, que dicho cuerpo, está sustentado ampliamente en la Constitución, la ley y la jurisprudencia; que en particular el Consejo de Estado y la Corte Constitucional, se han ocupado pródigamente del

\footnotetext{
${ }^{36}$ Este precepto tiene su fuente en la constitución, la ley y la jurisprudencia y aparece conceptuado en el artículo 209 C.P y el artículo 3 de la Ley 1437/11. Sentencia Corte Constitucional C- 693 DE 2008 Mp Marco Gerardo Monrroy Cabra
} 
tema, en tal sentido, a la administración no queda espacio para pretender desconocer su aplicación.

En síntesis del análisis del primer capítulo, se puede decir que se hahallado claridad en torno a los conceptos de principios y reglas; una primera apreciación con fundamento en la tendencia más generalizada en la actualidad, es la de reconocer que los dos conceptos tiene la categoría de normas jurídicas dentro del sistema jurídico.Así por ejemplo,los principiosse conciben como verdaderas normas que contienen mandatos obligatorios y exigibles y por tanto son aplicables a una generalidad de casos; de suerte que son caracterizados como directrices orientadoras de toda la acción contractual.

No obstante de dicha apreciación, se pueden evidenciar una serie de diferencias derivadas del campo de aplicación y de los casos donde se apliquen, así como la determinación del juicio de validez, el carácter rígido, particular y estático de las reglas, frente ala universalidad, movilidad, versatilidad, y adaptabilidad que caracteriza a los principios ante las distintas situaciones normativas.

El método de la ponderación se constituye en un elemento diferenciador de las categorías porque, permite que en caso de colisión entre principios no se vean afectados en su pretensión de validez, sino que existe un balance respecto al mayor peso relativo, que se debe otorgar a uno frente al otro sin menospreciar el estatus normativo de cada uno de ellos. Mientras que la regla por el contrario, se aplica o no se aplica y en caso de colisión entre reglas una de ella debe prevalecer, convirtiéndose en la regla válida, en tanto que aquella que no se aplica estará condenada a la invalidez.

Se concluye que la teoría de los principios es opuesta al tradicional sistema de reglas, de permisos y prohibiciones, contenida en los modelos constitucionales positivistas y organicistas del Estado, en tanto, las teorías modernas del neoconstitucionalismo, acoge la hipótesis, dónde los problemas se pueden solucionar mediante la aplicación de un sistema de principios, previamente conformado en los ordenamientos jurídicos internos.De 
este modo, los principios deben ser incorporados a la construcción normativa de las decisiones judiciales, con fundamento en los marcos constitucionales, para que el operador judicial pueda determinar si una restricción particular es irracional y le permita establecer la decisión, más razonable y proporcional para el caso en concreto.

Así las cosas, se considera que los principios son axiomas que hacen parte del derecho, en tanto, contribuyen en su desarrollo ynos acercan a conceptos flexibles, abiertos y justos de las ciencias jurídicas, para alejarnos del ámbito puramente mecanicista y rígido de mundo de la regla.

Enel contexto relativo a los principios que rigen la contratación estatal colombiana señalando,se concluye que según la doctrina los principios soncategorías que inspiran toda la regulación administrativa, aun cuando no se encuentren expresamente en forma legal. Debe rescatarse que la categoría de principios y reglas ha tenido su discusión e incidencia en el ordenamiento jurídico colombiano, y para el caso particular en lo que tiene que ver con el régimen contractual de las entidades estatales, se conciben como categorías diferenciadoras, porque los principios son tratados como preceptosorientadores del sistema normativo, en tanto, que reglas mantiene esa particularidad de contener mandatos imperativos aplicables, con la correspondiente consecuencia jurídica.

Quedaclaro que existe una variada gama de principios y reglas aplicables a la contratación pública del Estado, donde los principios son los que orientan la actividad administrativa del Estado, por estarcontenidos en el artículo 209 de la Carta, sin embargo, en esa lista taxativa de principiosconsagrado en el artículo 29 de la ley 80, no se incluyó a la selección objetiva como principio, sino con la denominación de deber de selección objetiva, lo cual fue replicado en el artículo 5 de la ley 1150, de modo que por la literalidad y contenido, el legislador lo concibió como una regla que debe ser aplicada por las entidades del Estado en el trámite de las actuaciones contractuales y no como un principio orientador del sistema. 
La profesora Deik (2014), al referirse a los principios de la contratación estatal nos dice: "A nuestro entender, además de los mencionados principios de trasparencia, economía, responsabilidad y los de la función administrativa, este régimen se encuentra fundado también en los principios de Selección Objetiva y Planeación, aunque hasta el momento la doctrina continua debatiendo sobre la naturaleza jurídica de uno y otro. (P.31).

Por el contrario la jurisprudencia, mantiene y acoge el enfoque y las coincidencias, expuestas por la doctrina, en el sentido de señalar diferencias significativas entre los dos preceptos al advertir que las reglas son imperativos categóricos o hipotéticos, que deben ser obligatoriamente cumplidos en la función contractual, por parte de los funcionarios de la administración pública, mientras que los principios, si bien mantienen un carácter de obligatoriedad en su aplicación, son directriz orientadores de la aplicación de las reglas, que se condensan en el ordenamiento normativo y cumplen una función integradora del sistema.

Lo cierto es que, para adentrarnos en el segundo capítulo, debo parafrasear a la profesora Deik (2014), quien indica en su obra que la ley 80 no desarrollo la selección objetiva como un principio, como si lo hizo con los de trasparencia, economía y responsabilidad, por el contrario afirma que el legislador de 1993, entendióel deber se selección objetiva como "un criterio de escogencia del contratista" de ahí que sea usual encontrar referencias a la selección objetiva como criterio $^{37}$; afirma la autora que la ley 1150 le otorgo el tratamiento de "deber" 38 " pero que con todo y lo anterior en muchas ocasiones, este beber ha recibido el tratamiento de "principio"39", posición esta última por la que se inclina la autora, al

\footnotetext{
${ }^{37}$ Cose hace en el sentencia C-392 DE 2007 de la Corte Constitucional

${ }^{38}$ Deber resaltarse que las motivaciones del proyecto de ley No. 20 de 2005, que luego se convirtió en la ley 1150, publicado en la Gaceta del Congreso No. 458 del 1 de agosto de 2005, se expresó "piedra angular de la apuesta que hace le proyecto por la obtención de los objetivos concurrentes de eficacia y trasparencia se encuentran en la reformulación del deber de selección objetiva"

39 Ver: COLOMBIA CONSEJO DE ESTADO, SALA DE LO CONTENCIOSO ADMINISTRATIVO, Sección tercera, Auto del 14 de Mayo de 2014, Exp, 50,222, Bogotá D.C. Mauricio Fajardo Gómez. También la autora hace alusión al artículo 30 del derogada decreto 2681 en el que se hace alusión expresa a la selección objetiva como un principio, razones que la llevan a considerar esa postura como acertada.
} 
considerar que el fundamento legal, se encuentra en el parágrafo 2 del artículo 24 de la ley 80, donde se hace mención a la selección objetiva como un principio. Discusión que tratara de remembrarse en el capítulo siguiente.

\section{CAPITULO 2}

\section{LA REGLA O EL PRINCIPIO DE LA SELECCIÓN OBJETIVA EN LA CONTRATACIÓN PÚBLICA COLOMBIANA}

En estecapítulo se pretende hacer una mirada de la selección objetiva en la contratación pública colombiana, con el fin de determinar si los enfoques doctrinales y jurisprudenciales, la considerada como principio o como una regla y cuáles son losalcanceslegales de tales apreciaciones, para luego aterrizar dicha concepción en el desarrollo de la legislación nacional.

Adicional, se busca con el desarrollo del capítulo, argumentos que posibiliten establecer la conveniencia o no, respecto de considerar y aplicar la selección objetiva como principio, como regla o deber, dentro de los proceso de selección de los contratistas y las implicaciones en ámbito administrativo, penal, disciplinario y fiscal, para las entidades y los funcionarios públicos.

\subsection{Antecedente normativo de la selección objetiva enla contratación colombiana.}

Los antecedentes regulatorios de la contratación estatal en Colombia, se remontan al decreto ley 150 de 1976, normativa que no contemplaba la selección objetiva, ni como principio ni como regla en la contratación Estatal, para aquella época se establecieron los llamados criterios para la adjudicación, que debían ser tenidos en cuenta por la administración al momento de adjudicar a un licitante, siempre que su oferta fuere la más favorable y se ajustara a las condiciones establecidas por la administración. 
Con el advenimiento del decreto 222 de 1983, en su artículo 33 se contemplaban los llamados requisitos, para la escogencia del contratista, dentro de los que se contemplaba el, precio, el plazo, la calidad, el cumplimiento de contratos anteriores, solvencia económica capacidad técnica, organización, equipos y experiencia de los oferentes.

La ley 80 de 1993, consagro el deber de la selección objetiva, teniendo en cuenta que en su momento señaló que:“Es objetiva la selección en la cual la escogencia se hace al ofrecimiento más favorable a la entidad y a los fines que ella busca, sin tener en consideración factores de afecto o de interés y, en general, cualquier clase de motivación subjetiva". (Artículo 29 de la ley 80, 1993). De la literalidad del enunciado podría pensarse que, al hablarse del deber de la selección objetiva estaríamos de entrada ante una regla impuesta por el legislador a todas las entidades del Estado en el trámite de los proceso de selección de contratistas, sin embargo, basta escudriñar en distintos apartes de la citada ley para encontrar una aparente contradicción en la denominación que quiso brindar el legislador a dicho precepto.

Así por ejemplo el parágrafo 2 del artículo 24 de la ley 80, al referirse a la obligación del gobierno nacional de expedir un reglamento para la contratación directa recabo que dichas disposiciones deberían garantizar y desarrollar los principios de economía, trasparencia y selección objetiva, previstos en la ley. De igual manera, el parágrafo 3 del mismo artículo 24 al referirse a la venta de bienes de las entidades estatales expreso que la selección de la entidad vendedora la hará la respectiva entidad estatal, de acuerdo con los principios de transparencia, economía, responsabilidad y selección objetiva.

A su paso, el artículo 38 de la citada ley al referirse al régimen especial de las entidades estatales que prestan servicios de telecomunicaciones, señala que los procedimientos que adopten esas entidades para el cumplimiento de las disposiciones 
previstas en dicha normativa deberán desarrollarse bajos principios de selección objetiva, transparencia, economía y responsabilidad establecidos en esta ley.

La ley 80 de 1993, fue derogada parcialmente por la ley 1150 de 2007, esta nueva disposición legal, en materia de principios ordena con fundamento en lo dispuesto en el artículo 13, que las entidades públicas deben acogerse y aplicar los principios de la función administrativa contemplados en los artículos 209 y 267 de la Norma Superior.

La ley 80 de 1993, en palabras del profesor Solarte (2010), justifica su existencia en el régimen jurídico colombiano, en la medida, en que sus reglas hagan posible el cumplimiento del principio de trasparencia que permite la selección objetiva de los contratistas del estado. Pareciera que para algún sector de la doctrina, la selección objetiva viene siendo una regla que desarrolla el principio de la trasparencia y dicha posición se afianza más cuando, decimos que, los pliegos de condiciones en los procesos de selección de contratistas deben contener reglas claras, objetivas y justas. Al respecto Guecha (2010) dice que, el pliego de condiciones en principio y en cuanto a los factores de selección, lo que hace es establecer criterios de comparación, ponderación y evaluación, ya que en sí, los factores ya están previstos de manera genérica en la ley, cuando el artículo 5 de la ley 1150 de 2007 refiere los mismos.

Sin embargo, algunos, Mendoza y García (2009) se refieren a la reformulación del principio de selección objetiva, al que se llega a partir de la expedición de la ley 1150 de 2007, al establecer los famosos criterios de "pasa" y "no pasa", situación que conllevo a una separación entre los requisitos del proponente y de la oferta. Lo anterior no es otra cosa que la manifestación de ese precepto de la selección objetiva cuya naturaleza hemos tratado de descifrar en este trabajo y que cobra gran relevancia, pues atañe nada más ni nada menos que a la selección de contratistas del estado, y en la que, según lo expone Bermúdez (2010) se deben distinguir dos aspectos, el criterio con el cual el estado realiza la 
escogencia ${ }^{40}$ y el procedimiento que utiliza para tal fin $^{41}$. De donde podemos extraer que, si es cierto, genéricamente hablamos de selección de contratistas, la selección objetiva se desarrolla circunscrita únicamente a "los criterios de escogencia" que deben tenerse en cuenta en los términos del artículo 5 de la ley 1150.

Teniendo en cuenta las anteriores precisiones normativas y retomando la discusión, la jurisprudencia, en numerosas sentencias ha reiterado, la diferencia que existe entre regla y principio y advierte la importancia de la aplicación de los principios como axiomas orientadores de la regla en la función contractual estatal. Respecto al tema de la selección objetiva en Colombia, como un principio de la contratación estatal, que involucra una regla o deber, sin realizar ninguna precisión o distinción entre lo que es una institución y otra, la Corte Constitucional, se refiere al tema en los siguientes términos: "El principio de escogencia o selección objetiva de los contratistas fundamenta uno de los principales deberes de todos los responsables de la contratación estatal". (Corte Constitucional, sentencia C- 128 de 18 de febrero de 2003. MP. Álvaro Tafur Galvis).

El Consejo de Estado en varias ocasiones se ha referido al tema, en los siguientes términos: "La selección objetiva es un deber-regla de conducta- en la actividad contractual, un principio que orienta los procesos de selección". (Consejo de Estado, 3 de diciembre de 2007. Expediente 31447, C.P. Ruth Estela Correa). de igual forma, ha expresado: "Ahora bien, la experiencia, como factor de escogencia, conforme al principio de selección objetiva, se entiende como el conjunto de conocimientos, habilidades y destrezas adquiridas o desarrolladas mediante el ejercicio de una profesión, ocupación u oficio."(Consejo de Estado, 14 de abril de 2005. Expediente 25094, C.P. German Rodríguez Villamizar).

\footnotetext{
40 Por ejemplo, para el caso de los bienes de características técnicas uniformes y de común utilización el mismo artículo 5 que desarrolla la selección objetiva establece como único criterio para realizar la escogencia el menor precio, prohibiendo a su paso la consideración del mismo en la selección de consultores.

${ }^{41}$ El procedimiento está dado por las modalidades de selección que establece el artículo 2 de la ley 1150.
} 
En la sentencia del 7 de octubre de 2009, el Consejo se ha referido a la selección objetiva de la siguiente forma:

Si la ley, en desarrollo del principio de selección objetiva, enlistó algunos criterios a manera de enunciación para que fuese la administración la que determinase en cada caso concreto, y según las necesidades del servicio, al reglamento no le es dable variar esta decisión del legislador para, en su lugar, imponer una diversa. Por otra parte, tal y como lo afirman los demandantes, de conformidad con el numeral $5^{\circ}$ del artículo 24 y el numeral $2^{\circ}$ del artículo 30 de la Ley 80 de 1993, los pliegos de condiciones o los términos de referencia que se deben elaborar por la entidad pública con la debida antelación a la apertura del proceso son los instrumentos que hacen realidad el deber de selección objetiva, como quiera que determinan las reglas que posibilitan la selección de la propuesta más favorable". (Consejo de Estado, 7 de octubre de 2009. Expediente 11001032600020100003800 (39.040), C.P. Ruth Estela Correa).

De igual manera, en la sentencia del 20 de mayo 2010, expresó: "La selección objetiva, según lo enseña la jurisprudencia de la Sección Tercera del Consejo de Estado, es una regla de conducta de la actividad contractual, así como un principio que orienta los procesos de selección tanto de licitación pública como de contratación directa, y un fin, pues apunta a un resultado, cual es, la escogencia de la oferta más ventajosa para los interesescolectivos perseguidos con la contratación". (Consejo de Estado, 20 de mayo de 2010. Expediente 11001-03-06-000-2010-00034-00 (1992). C.P. Enrique José Arboleda).

Delos textosjurisprudenciales, se puede leer que las Cortes al referirse a la selección objetiva, no se detienen hacer un análisis completo tendiente a diferenciar los conceptos de principio o regla; por el contrario, le otorgana la selección objetiva,indistintamente una u otra categoría, de suerte que el panorama no se encuentra muy claro, lo cual, solo permite adicionar una razón máspara expresar en las próximas líneas algunos planteamientos, que pueden contribuir a desentrañar si la selección objetiva obedece a un principio o a una regla de la contratación estatal en Colombia.

\subsection{La selección objetiva como principio de la contratación estatal.}


Empecemos esta parte del trabajo, haciendo un análisis de la selección objetiva, a la luz de los planteamientos hechos por algunos autores, la Constitución y las leyes de contratación estatal. Recordemos que para un sector de la doctrina los principios son verdaderas normas, porque igual que las reglas dicen lo que debe ser. Los principios son mandatos de optimización, por cuanto son normas que ordenan que algo sea realizado en la mayor medida de lo posible permitido, por las condiciones jurídicas y fácticas existentes. (Yong Samuel, 2013).

Así las cosas, con base en lo estudiado en el capítulo anterior, sepuede decir que los principios, en situaciones reales ceden su puesto frente a otros, es decir, que frente a un caso de colisión de dos principios en un juicio concreto, uno se aplica y el otro no, sin que ninguno pierda validez; sin embargo, para quienes le otorgan el carácter de principio de la contratación estatal a la selección objetiva, se hace necesario preguntar: ¿sien desarrollo de la actividad contractual, dicho principio debe o puede ceder frente a otro principio?, o peor aún, ¿si debe ser aplicado en cada proceso de selección en la mayor medida de lo posible, conforme a las posibilidades fácticas y jurídica existentes para cada caso concreto?.

Si bien es cierto, del concepto de principio se pueden forjar diferentes acepciones, para Yong (2013) "el estatuto contractual colombiano, le da un sentido particular, en cuanto lo concibe como una norma rectora que se debe aplicar en los procesos de contratación estatal, por quienes la realicen y seleccionen o interpreten una norma para aplicarla a un caso relacionado con aspectos contractuales".(p.43).

A este respecto, González (2010), considera que en la contratación pública colombiana, los principios que deben ser aplicados en los procesos de selección, constituyen un verdadero criterio orientador para los diferentes actores que confluyen al escenario público contractual, criterios orientadores que de no ser tenidos en cuenta, pueden afectar la validez de las actuaciones donde se pretermitieron. Los principios de selección deben orientar todo el contenido de los pliegos de condiciones de tal manera que su violación afecta la validez del pliego de condiciones y del proceso contractual, pues se 
encuentran consagrados en la ley o pueden extraerse de su contenido normativo.(pp. 60$61)$.

De igual forma, la Constitución de 1991, en el artículo 209, consagra los principios de la función administrativa del Estado, como principios de rango constitucional, no obstante que el constituyente no se haya referido a la selección objetiva en particular como principio de raigambre constitucional, la selección de los contratistas, se constituye en el ejercicio verdadero de la función administrativa del Estado, porsatisfacer el interés general.

Por su parte, la ley 1150 de 2007, ha considerado que es objetiva la selección cuando en la escogencia se haga el ofrecimiento más favorable a la entidad y a los fines que ella busca, sin tener en consideración factores de afecto o de interés y, en general cualquier clase de motivación subjetiva. En consecuencia, los factores de escogencia y calificación que establezcan las entidades en los pliegos de condiciones y sus equivalentes tendrán en cuenta los criterios señalados en la mentada disposición. (Artículo 5).

Para Rodríguez Libardo (2005), el tema de la selección objetiva, es clasificado como una institución cuando se referiré a ella en los siguientes términos:"un principio de la contratación estatal consagradoen el artículo 29 del estatuto, consistente enescoger el contratista que hace el ofrecimiento más favorable a la entidad y a los fines que ella busca, sin tener en consideración factores de afecto o interés y, en general cualquier clase de motivación subjetiva". (p. 403).

En la doctrina contemporánea encontramos que los autores se refieren a la institución de la selección objetiva como un principio de la contratación estatal sin detenerse en el análisis de si representa o no la categoría de principio.Tal es el caso de Molano Mario (2009), que concibió el estatuto como "una ley en cuyo texto se configuraran las reglas básicas de los principios rectores de la contratación estatal como en efecto lo son el articulo 24 al 30 en que se desarrollaron los principios de transparencia, economía, responsabilidad, selección objetiva y equilibrio económico y financiero del contrato 
estatal”. (p.29). Por su parte los profesores Castro, García y Martínez (2010) consideran que, el principio de objetividad tienen por objeto asegurar la igualdad de oportunidades y la selección del oferente más solvente y capaz, y que dicho principio tiene básicamente dos manifestaciones, por un lado la exigencia de establecer unas reglas claras previas y por otro que la adjudicación se decida única y exclusivamente con base a esas reglas previas.

Por su parte, Suarez Gonzalo (2009), dice que cuando el artículo 29 de la Ley 80, derogado por la reforma,definía el principio de selección objetiva, citaba los factores de selección objetiva mezclando en esa enunciación circunstancias atinentes al proponente y aquellas relativas a la oferta misma "de esta manera, resultaba potestativo de la entidad dar puntaje a circunstancias relacionadas con el proponente lo que en el peor de los casos permitía el direccionamiento de los procesos hacia un determinado proponente o hacia un grupo, con evidente perjuicio de la transparencia que debe presidir el proceso" (p. 60). Mientras que Santofimio Jaime (2009), considera que la norma que erige el principio de selección objetiva, debe interpretarse de manera conjunta e integrada con los demás principios orientadores de la actividad contractual, como lo son la de la trasparencia, economía, y responsabilidad, consagrados en los artículos 24, 25 y 26 de la ley 80 de 1993. (p. 60).

Para Castro Carlos (2011), el principio de selección objetiva tiene por objeto asegurar la igualdad de oportunidades y la selección del oferente, y por lo tanto, tiene diversas manifestaciones. (p. 29). Para el Profesor David Suarez, la Selección Objetiva es un principio base de la contratación estatal, al afirmar que: "se deriva de los arts. 6 y 121 124 C.P en concordancia con el artículo 5 Ley 1150/07”. (p.106). Mientras que para Fandiño (2014), la selección objetiva es uno de los principios más importantes en los procesos de selección, propio de todas las modalidades de selección de contratistas. Considera que este principio no significa pluralidad de oferentes, porque si bien la selección debe propiciar la concurrencia de oferentes, lo es también que en algunos casos la escogencia podrá realizarse con la presencia de un solo oferente. Se trata de escoger la mejor oferta más favorable en cuanto no pueden aparecer consideraciones de orden 
subjetivo para realizar la selección del contratista, tales como razones políticas, de raza, credo o nacionalidad y observar las reglas que dispone la ley, para asegurar el ofrecimiento más favorable. (p.145).

Nótese que la doctrina traída al escenario de la investigación, tiene una ligera inclinación conceptual al considerar a la selección objetivacomo un principio o un deber y dista un poco a creer que es regla.La mayoría de los autores coinciden en afirmar que es un principio esencial en los proceso de contratación estatal y un deber para las entidades que se debe llevarla a cabo en los pliegos de condiciones, consideraciones que compartimos por ser más afines con el término y concordante con el fin que se persigue.

También se observa que los planteamientos descritos, reconocen que la selección objetiva es un principio de la contratación estatal, inmerso en los procesos de selección de contratistas tramitados por las entidades estatales, dicha acepción tiene sustento jurisprudencial, donde también se reconoce como verdadero principio de contratación estatal.Sinembargo, es necesario precisar que en la mayoría de las ocasiones la jurisprudencia, trata indistintamente al término de selección objetiva, sin dar importancia a la categoría como tal. A continuación se revisará lo que dice la jurisprudencia sobre el principio de la selección objetiva.

\subsection{La selección objetiva a la luz de la jurisprudencia.}

En la sentencia C-949, en virtud de laimportancia del principio de selección objetiva del contratista para los fines del Estado, la Corte subió la licitación o concurso público como procedimiento de selección del contratista, al rango constitucional por excelencia dirigido a la selección objetiva. En particular, la Corporación resalto la importancia de los principios de libre concurrencia y la igualdad entre proponentes, como fundamentos esenciales del proceso de contratación estatal.(Corte Constitucional, sentencia-949 de 2001. MP. Clara Inés Vargas); es más, la Corte en la sentencia C-400, determina que el constituyente le confirió categoría de validez jurídica a la licitación pública, al dejarlo 
expresamente mencionado en el artículo 273 Superior. (Corte Constitucional, sentencia-400 de 1999. MP. Vladimiro Naranjo Mesa). Vale aclarar que aunque la Constitución Política en el mencionado artículo, solo se refiere a la licitación pública como modalidad de selección, no está por demás concebir que dicha validez jurídica se extiende a la figura de la selección abreviada, al concurso público y la contratación directa.

Para el consejo de Estado $^{42}$, la selección objetiva la reconoce como uno de los principios orientadores de la contratación estatal, al incluirlo dentro de la variada gama de principios orientadoresde la contratación, cuando señala:

\begin{abstract}
Al igual que ocurre en todos los contratos estatales, la escogencia del contratista se debe hace siguiendo los principios orientadores establecidos en la ley: selección objetiva, economía, trasparencia, entre otros. Los pliegos de condiciones deben tener claramente definidos, los requisitos para participar dentro del proceso licitatorio, así como la minuta del contrato que se pretende celebrar. Es por ello que la experiencia exigida al proponente es un requisito que permite predicar la selección objetiva. (Consejo de Estado, Sección Tercera, sentencia de junio de 4 de 2008. MP. Miriam Gurrero de Escobar. Exp. 17783).
\end{abstract}

Son muchas las referencias que pueden encontrarse en la doctrina y en la jurisprudencia que hacen alusión al principio de la selección objetiva, y en ese intento por definir la categoría a la que pertenece dicha institución, encontramos que en los escenarios en donde se le otorga la categoría de principio, es muy notable que emerjan características como la generalidad del criterio mismo, que lo convierte en una directriz o derrotero que guía los procesos de selección de contratistas, que se tramitan en las entidades del Estado, cuyo único fin debe ser la satisfacción del interés general.

Conforme a la jurisprudencia del Consejo de Estado, la selección de contratistas para cumplir con el requisito de objetividad debe caracterizarse por: 1) Ausencia total de subjetividad; 2) Estar determinada por la comparación de distintos factores, establecidos

\footnotetext{
${ }^{42}$ El Consejo de Estado se pronuncia al tema de la justicia arbitral, con ocasión del fallo surgido por controversia contractuales entre la Promotora de Construcciones e Inversiones Santana S.A. vs Distrito Capital de Santafé de Bogotá vs Compañía Aseguradora de Finanzas S.A el 18 de diciembre de 2000.
} 
con anterioridad por la Administración en el pliego de condiciones; 3) Estar determinada la forma como los factores de selección serán evaluados y el valor que corresponde a cada uno de ellos en el pliego de condiciones; 4) Estar determinada la adjudicación y celebración del negocio jurídico por un análisis, comparación y evaluación objetiva de las propuestas presentadas. (Consejo de Estado, Sección Tercera, sentencia de junio de 4 de 2008. MP. Miriam Gurrero de Escobar. Exp. 17783).

Sibien es cierto, existe una línea jurisprudencial y doctrinal que reconoce a la selección objetiva como un principio de la contratación estatal, no puede desconocerse que para la materialización de dicho principio se han creado una serie de requisitos, o se han desagregado una serie de factores que deben estar presentes en el proceso de selección de contratistas, y deben ser estructurados por cada entidad de manera previa al inicio de cualquier proceso de selección, lo que implica en primera medida que, la selección objetiva se encuentra supeditada a la existencia de un proceso de selección de contratistas, pues es en el marco de los procesos de selección donde se exige precisamente cualquier ausencia de subjetividad, donde debe existir una comparación minuciosa de las ofertas, de cara a unos criterios previamente establecidos, que impliquen una verdadera selección objetiva de la oferta que sea más favorable a la entidad.

Si el principio de la selección objetiva, se da en el marco de unos procedimientos de selección previamente establecidos por el legislador, ¿qué pasa cuando dichos procedimientos no existen, por mandato legal?, como en el caso de la urgencia manifiesta, ¿sería factible pensar que en dicho caso,nos encontramos frente a una colisión de principios, en donde debe ceder la selección objetiva frente a otros principios de mayor categoría?, o ¿será mejor pensar en que la urgencia manifiesta, que en palabras del profesor Alexy, es una cláusula de excepción, prevista por el legislador para dirimir un conflicto entre reglas?.

Aceptamos entonces que la selección objetiva debe ser vista como un principio rector de la contratación estatal que se da en el marco de un procedimiento de selección de 
contratistas,que los principios son verdaderas normas que contienen mandatos obligatorios y exigibles,pero que sin embargo no dejan de caracterizarse por su generalidad, lo que hace que sean aplicables a una generalidad de casos. No obstante, elcriterio de la generalidad que reviste a los principios tiende a desaparecer, si nos atenemos a la literalidad del texto contenido en el derogado artículo 29 de la ley 80 y en el actual artículo 5 de la ley 1150 de 2007, donde se establece claramente unos criterios que se deben tener en cuenta por las entidades estatales, para la escogencia de la oferta más favorable, haciendo así de la generalidad que reviste al principio una particularidad y especificidad propia de las reglas.

Ahora bien, ¿si la selección objetiva es un principio, podría existir la posibilidad, en un determinado caso, que dicho principio colisionara con otro y que tuviera que ceder y ser inaplicado al resolver dicha colisiónbajo los criterios de ponderación?Esta es una pregunta que queda por resolver porque en el ejercicio propio de un proceso de selección, son muchas la variables que entran en juego y la entidad no se detiene a confrontarlas, pues lo importante es cumplir el fin, cual es el de seleccionar la oferta más favorable.

Además, el principio de la selección objetiva como se encuentra concebido en la actualidad, no puede decirse que tenga un carácter universal, móvil o cambiante o que sea adaptable ante distintas situaciones; todo lo contrario los criterios previstos en el artículo 5 de la ley 1150 enuncian unas prerrogativas que deben ser cumplidas para cada modalidad de selección de contratistas, sin que fuere predicable entonces decir, que el principio de la selección objetiva se cumple en mayor o menor grado en cada caso particular.

Todos estos interrogantes abren la puerta para dudar, de la selección objetiva vista como un verdadero principio de la contratación estatal, y nos llevan a analizar si tal precepto, tendría cabida en el campo de las reglas. Sobre el particular cabe resaltar que la doctrina contemporánea más autorizada sobre la materia se ha cuestionado sobre la categoría que ha de otorgase, al concepto de la selección objetiva, en esta dirección el profesor Matallana (2009), reconoce la selección objetiva como un principio al afirmar que:"Como complemento del principio de selección objetiva se introdujo por parte el 
legislador una norma que excluye la posibilidad de eliminar ofertas cuando se trate de documentos no comparativos de ofertas; se garantiza con ello el mayor número de ofertas para escoger la que ofrezca las mejores condiciones para la entidad”.(p. 473).Sin embargo, el autor reconoce acertada la crítica hecha por el Profesor Juan Carlos Expósito Vélez (2009), quien considera la selección objetiva como un deber de las entidades y no un principio de la contratación estatal, al expresar:

En consecuencia, podemos concluir que la selección objetiva no es simplemente un principio de la contratación estatal que la administración debe tratar de cumplir, si no que se trata de un auténtico deber, que estructurado como regla jurídica es de imperativo cumplimiento para la administración respecto de todas las tipologías contractuales y en todos los procedimientos de selección de contratistas. (p.139).

De lo expuesto, se puede observar que los esfuerzos hechos por la doctrina y la jurisprudencia no han sido suficientes para concluir con certeza absoluta, el hecho de que la selección objetiva sea un principio o una regla, no obstante que ambas, en algunos momentos hayan llegado a reconocer que dicha institución, pertenece a la categoría de los principios.

En otras palabras, aunque podemos sostener que la selección objetiva es un concepto jurídico indeterminado, y como tal debe ser precisado en cada situación en particular, no escapa de la esencia de su definición que la elección del contratista debe obedecer exclusivamente a una decisión neutral y por lo tanto producto de una administración imparcial, esto es, sujeta única y exclusivamente al interés general.

\subsection{La selección objetivacomo deber.}

Al concluir el segmento anterior, se trajo al escenario la línea defendida por el profesor Expósito Vélez (2009), quien estima en palabras más, palabras menos, que la selección objetiva no es un principio de la contratación estatal, sino un deber que configurado como regla tienen y deben cumplir todas las entidades del Estado en la 
selección de los contratistas, criterio que es mantenido por el autor y afianzado en uno de sus trabajos académicos más recientes, en donde sobre el particular señala:

(...)La finalidad de todas las anteriores modalidades de selección de contratistas es dar efectividad al deber de selección objetiva, de tal manera que se garantice, la escogencia de la oferta más favorable a los intereses de la entidad, previo cumplimiento de los requisitos habilitantes señalados en el artículo 5-1 de la ley 1150 de 2007(...).

(...) Todo lo anterior implica que la selección de los contratistas de la administración se constituye en una formalidad básica, para la configuración y correcta ejecución del contrato estatal, como pilar fundamental de la figura, ya que el cumplimiento del deber de selección objetiva se concreta mediante la realización de procedimientos que permitan la libre concurrencia de los particulares y garanticen la elección justa e imparcial de la mejor propuesta, para los intereses de la entidad"(Expósito Juan, 2013. p. 60).

En la misma dirección, Rico Puerta (2012), reconoce que: “(...) la ley 80 de 1993 estableció en su artículo 29, el deber de selección objetiva de contratistas (...)”.Refiriéndose al decreto 734 de 2012 afirma que, “(...) dicha convocatoria tiene una relación directa con el deber de selección objetiva (pp. 355 y 375).

Se desprende de las apreciaciones del autor que en el texto de la ley 80 de 1993, la selección objetiva, fue concebida como un deber y no como un principio, en tanto, señala expresamente que esta actividad contractual es un deber para la entidad, atendiendo a los criterios establecidos y no a criterios subjetivos de la entidad. En este tenor, otros tratadistas como el profesor Edgar González, expone:

(...) la selección objetiva no es un principio, sino una finalidad instrumental del proceso contractual; vale recordar que el fin corresponde a la aspiración que se quiere llegar, mientras que el principio supone los pensamientos generales normativos que han orientado la labor del legislador o que prescriben que un valor o un bien jurídico debe ser realizado en la mayor medida que resulte posible" (González, Edgar, 2010, p.135)

Es claro entonces, que algunos autores no le otorgan a la selección objetiva la categoría de principio, por el contrario demuestran una tendencia a considerarla como un deber o un instrumento dentro del procedimiento de selección de contratistas que debe ser aplicado por las entidades estatales en la selección de sus colaboradores. 
Por su parte laCorte Constitucional en sentencia C-128 de 2003expreso:

\begin{abstract}
El principio contemplado en el artículo $3^{\circ}$ del proyecto, según el cual tanto los servidores públicos como los particulares que contratan con la administración deben obrar bajo el claro e inequívoco entendimiento de que una de las finalidades esenciales de la contratación estatal la constituye, precisamente, el cabal cumplimiento de los cometidos estatales, impone partir del criterio de la buena fe de sus actuaciones e implica, por ello, la simplificación de trámites, requisitos y procedimientos, en el ámbito de un estricto régimen de responsabilidad correlativo. Dicho principio encuentra un complemento de significativa importancia consistente en el deber de escoger al contratista mediante la selección objetiva, aspecto éste que el estatuto anterior no contemplaba de manera explícita. (Corte Constitucional, sentencia C-128 de 2003, M.P. Álvaro Tafur Galvis).
\end{abstract}

En ese sentido, Jorge Bendeck (1992), en la exposición de motivos de la ley 80 de 1993, expone que: "los artículos 24 y 29 del proyecto consagran expresamente ese deber de aplicar tal criterio de escogencia del contratista, para resaltar cómo la actividad contractual de la administración debe ser en un todo ajena a consideraciones caprichosas o subjetivas y que, por lo tanto, sus actos deben llevar siempre como única impronta la del interés público". (Gaceta del Congreso № 75 del 23 de septiembre de 1993).

Para entender la selección objetiva como un deber que deben cumplir todas las entidades del Estado y por lo tanto, es necesario distinguir las dos aristas que demarca el camino que debe seguirse en la aplicación de dicha regla; la primera de ellas, implica la obligación que tiene la entidad de confeccionar los estudios previos y pliegos de condiciones desde la fase misma de planeación del proceso de selección, de tal manera que los parámetros allí fijados, obedezcan a factores eminentemente objetivos y se sigan claramente los criterios determinados por el artículo 5 de la ley 1150 dependiendo cada una de las modalidades de selección. La segunda arista que compone el deber de selección objetiva, parte del hecho que una vez confeccionadas las condiciones netamente objetivas y en los términos previstos por el artículo 5 de la le 1150, la comparación y calificación de las ofertas debe hacerse de cara a las reglas objetivas previamente establecidas, sin salirse de ellas, sin ir más allá, o más acá que de lo estrictamente en ellas contenido. 
Sobre el particular el Consejo de Estado en un pronunciamiento muy reciente, manteniendo la aparente confusión literal al referirse a la selección objetiva como un principio, termina dejando claro que es un deber irrestricto que deben cumplir todas las entidades del Estado en la selección de sus oferentes, cuando se referir en los siguientes términos:

En relación con el deber de selección objetiva, se trata de un principio que rige la contratación de las entidades estatales, por cuanto a través del mismo se propende por lograr una selección de contratistas imparcial, ajustada exclusivamente a los parámetros de evaluación y calificación establecidos en forma clara, concreta y completa por el pliego de condiciones o términos de referencia -los cuales deben apuntar únicamente a la determinación de la oferta que en conjunto ofrezca las mejores condiciones para la ejecución del objeto propuesto- y ajena a cualquier consideración de índole subjetiva y personal dirigida a favorecer o perjudicar a alguno de los proponentes, sin la interferencia de tratos preferenciales o injustos que atenten contra el principio de igualdad frente al proceso de selección -que implica brindar un tratamiento idéntico para todos los oferentes en las mismas condiciones- y desligada de cualquier influencia externa que la desvíe de su finalidad, cual es la de lograr la correcta y cumplida ejecución del objeto contractual por quien presentó la mejor oferta y cumplió con todos los requisitos exigidos.

Este deber de selección objetiva debe cumplirse no sólo cuando se adelantan procedimientos licitatorios o concursos de méritos, sino en toda actuación que se adelante con miras a la selección de un contratista de la administración, puesto que ni siquiera cuando el ordenamiento legal autoriza la contratación directa, puede la administración escogerlo de manera subjetiva y arbitraria, ya que este mecanismo de contratación no se traduce en una facultad discrecional e independiente del funcionario competente para adjudicar ni queda librada a su solo deseo o voluntad, puesto que también en estos casos, se le exige efectuar la adjudicación de manera objetiva, es decir desligada de consideraciones de índole íntima y personal y libre de la influencia de intereses particulares, con fundamento exclusivamente en los factores de evaluación previamente establecidos e informados a los proponentes, con observancia estricta del principio de igualdad y con el único fin de seleccionar la oferta más favorable para la administración y para el cumplimiento de sus fines (Consejo de Estado, Sección Tercera, sentencia del 29 de julio de 2013, MP. Danilo Rojas Betancourth. Radicación: 25000-23-26-000-1995-01712-01).

El deber de selección objetiva, desde su génesis el artículo 29 de la ley 80ha señalado unos criterios concretos y específicos que deben ser aplicados en la selección de contratistas, conforme a la modalidad de selección que particularmente deba escogerse, de suerte que se impone una obligación de elegir a la mejor oferta lejos de cualquier consideración subjetiva.De la lectura del texto se infiere que se constituye en un mandato legal, la objetividad de la selección en la escogencia del ofrecimiento más favorable para la 
entidad y los fines que persigue con la contratación, sin tener en consideración factores de afecto o de interés y, en general, cualquier clase de motivación subjetiva.

En este sentido, la procuraduría (2006), advierteque el deber de selección objetiva recoge dos aspectos diferentes, a saber: El primero, la prohibición absoluta del subjetivismo y el segundo, que la selección se haga sobre la base de una pluralidad de factores que le permitan a la entidad estudiar y evaluar las propuestas desde diferentes puntos de vista, efectuando las comparaciones entre ellas para seleccionar al mejor proponente. (Procuraduría General de la Nación,fallo del 20 de noviembre de 2006, expediente 038-5816).

Sin embargo, el Consejo de Estadoen el 2010, había considerado que la selección objetiva además de ser una regla es también un principio orientador de los procesos de selección pública al expresar:

\footnotetext{
La selección objetiva, según lo enseña la jurisprudencia de la Sección Tercera del Consejo de Estado, es una regla de conducta de la actividad contractual, así como un principio que orienta los procesos de selección tanto de licitación pública como de contratación directa, y un fin, pues apunta a un resultado, cual es, la escogencia de la oferta más ventajosa para los intereses colectivos perseguidos con la contratación. El Legislador al definir lo que se entiende por selección objetiva, pretende regular la escogencia de la mejor oferta mediante un proceso en el que prime la transparencia, la imparcialidad e igualdad de oportunidades, ajena a consideraciones subjetivas, para lo cual juegan un papel preponderante los factores y criterios de selección que en función de la específica necesidad pública haya fijado la administración en los pliegos de condiciones. Por estas razones la consagración legal del deber de selección objetiva se enmarca dentro de la institución del acto reglado. Una decisión administrativa encaja en la noción de acto reglado cuando su contenido es el único posible en razón de la ley y los reglamentos, siendo ilegal si los desconoce. (Consejo de Estado, Sala de Consulta y Servicio civil, sentencia del 20 de mayo de 2010, MP. Enrique José Arboleda, Radicación: 11001-03-06-000-2010-00034-00(1992).
}

Ahora bien, si para el Consejo de Estado, la selección objetiva tiene el carácter de deber y de principio orientador, existen argumentos válidos para considerar que el deber se constituye en regla y en tal sentido, sedebe acatar por todas la entidades del Estado en los procedimientos de selección, toda vez que obedece a un típico acto reglado de la administración que no puede ser desconocido, al otorgársele la categoría de discrecional; 
por esa razón, es débil inclinarse solo por la teoría de la selección objetiva como un principioporque como se encuentra configurado dicho precepto legal, se escapa de los criterios abstractos y de generalidad que reviste a los principios y no deja al arbitrio de quien lo aplica la posibilidad bajo ninguna circunstancia, de aplicarlo en la mayor medida de lo posible conforme a las posibilidades fácticas y jurídicas existentes, todo lo contrario, cada vez se afinca más la tesis de considerar a la selección objetiva una regla que involucra un deber insoslayable.

Así las cosas, se puede pensar que la selección objetiva, como se encuentra concebida en el artículo 5 de la ley 1150, obedece a un verdadero deber, o regla en sentido estricto, pues es una instrucción de conducta de carácter obligatorio validada según las pautas de producción normativa reconocidos en el ordenamiento jurídico y contiene un juicio de valor preestablecido, que regula conforme a los criterios contenidos en la disposición normativa que contiene dicha regla, la forma en que debe confeccionarse los requisitos y condiciones,y la forma en que deben ser evaluados para la selección de la mejor oferta, aplicables a todo los proceso de selección de contratistas sin distingo alguno. (Tamayo, 2010).

Del artículo 5 de la ley 1150, se puedenextraer una serie de reglas o lineamientos precisos que impuso el legislador a las entidades estatales para la escogencia de sus contratistas, los cuales deben ser aplicados, conforme se señala, y atendiendo a la modalidad de selección que corresponda. Como se viene afirmando, la finalidad de la regla contenida en la selección objetiva, es la escogencia de un colaborador de la administración, cuya propuesta resulte la más favorable, con el objetivo de lograr la satisfacción de las necesidades e intereses de la comunidad en general, sin que en dicha elección puedan interferir factores subjetivos de afecto, o intereses particulares, si no razones del servicio.La ley 1150 dispone: "Es objetiva la selección en la cual la escogencia se haga al ofrecimiento más favorable a la entidad y a los fines que ella busca, sin tener en consideración factores de afecto o de interés y, en general, cualquier clase de motivación subjetiva". (Artículo 5, ley 1150). 
En el citado artículo, la norma estable que los factores de escogencia y calificación que establezcan las entidades en los pliegos de condiciones o sus equivalentes, se deben tener en cuenta los siguientes criterios: 1) capacidad jurídica y las condiciones de experiencia, capacidad financiera y de organización de los proponentes, los cuales deben ser objeto de verificación de cumplimiento como requisitos habilitantes para la participación en el proceso de selección sin que otorguen puntaje, con excepción de lo previsto en el numeral 4 del presente artículo. 2) Laoferta más favorable debe ser aquella que, teniendo en cuenta los factores técnicos y económicos de escogencia y la ponderación precisa y detallada de los mismos, contenida en los pliegos de condiciones o sus equivalentes, resulte ser la más ventajosa para la entidad, sin que lafavorabilidad la constituyan factores diferentes a los contenidos en dichos documentos. 3) En los pliegos de condiciones para las contrataciones cuyo objeto sea la adquisición o suministro de bienes y servicios de características técnicas uniformes y común utilización, las entidades estatales el menor precio ofrecido debe ser único factor de evaluación. 4) En los procesos para la selección de consultores se hará uso de factores de calificación destinados a valorar los aspectos técnicos de la oferta o proyecto.

También señala, que la exigencia de tales condiciones debe ser adecuada y proporcional a la naturaleza del contrato a suscribir y a su valor y que la verificación documental de las condiciones antes señaladas será efectuada por las Cámaras de Comercio de conformidad, de acuerdo con lo cual se expedirá la respectiva certificación.

Respecto a los contratos de obra pública, establece que el menor plazo ofrecido no puede ser objeto de evaluación. La entidad efectuará las comparaciones del caso mediante el cotejo de los ofrecimientos recibidos y la consulta de precios o condiciones del mercado y los estudios y deducciones de la entidad o de los organismos consultores o asesores designados para ello. En ningún caso se podrá incluir el precio, como factor de escogencia para la selección de consultores. 
Al respecto Matallana (2013), dice que conla expedición de la ley 1150 de 2007, el esquema de la ley 80 se modificó sustancialmente, por cuanto se dividieron los criterios de evaluación de las ofertasen dos: por una parte aquellos que serían requisitos mínimos habilitantes que no generan la adjudicación de puntos como la experiencia, la capacidad financiera, la capacidad legal y la organización del proponente; de otra, en algunos casos (licitación pública y procesos de selección abreviada de menor cuantía) se ponderaran factores técnicos (calidad) y factores económicos (costo o costo-beneficio), en otros (concurso de méritos) los aspectos técnicos de la propuestas incluyendo el precio (hojas de vida y experiencia especifica del proponente), y, finalmente en otros (procesos de selección de bienes y servicios de características técnicas uniformes y de uso común entre las entidades estatales y el proceso de selección de mínimacuantía) no habrá ponderación e ofertas y se seleccionara la mejor oferta con el menor precio.(p. 510).

Nótese que el deber deselección objetiva consagrado en el artículo 5, estableció un parámetro general para todos los procedimientos de selección, donde la entidad está obligada a establecer los requisitos habilitantes de las propuestas, bajo los parámetros establecidos, sin depender de cada caso en particular; por ejemplo, sabemos que la capacidad financiera del proponente, será en general para la mayoría de los procesos de selección $^{43}$, un criterio habilitante que no otorga puntaje y que por tal puede ser subsanable; bajo ninguna circunstancia podría una entidad estatal otorgarle puntaje y calificar las ofertas que demuestren mayor o menor capacidad financiera, precisamente porque la regla que demarca el deber de selección objetiva establece claramente que la capacidad financiera es un requisito habilitante que no otorga puntaje, al punto que si una entidad estatal confecciona la regla para un determinado proceso en un sentido distinto al que en ella se señala pues incumple el deber de selección objetiva, con las consecuencias que ello puede derivar.

\footnotetext{
${ }^{43}$ Debe tenerse en cuenta que los procesos de contratación directa, no se encuentra reglado o definido específicamente el criterio e capacidad financiera como requisito de habilitación, sin embargo ello no quiere significar que no pueda ser tenido en cuenta en el marco de los criterios de idoneidad, capacidad y experiencia que deben examinarse.
} 
Se desprende palmariamente de la lectura de la norma, que la selección objetiva es concebida y tratada como una regla, cerrando la posibilidad de ser interpretada y aplicada como principio, en tanto, fija parámetros de regulación que no son discrecionales, sino de obligatorio cumplimiento, es decir, no deja eventualidad para elegir entre otras opciones de selección. Si la selección objetiva, fuera entendida como un principio que puede darse en la mayor medida de lo posible conforme a las posibilidades fácticas y jurídicas existentes, en un determinado momento cualquier entidad podría argumentar que frente a un caso en concreto, se aplicó un principio ante uno de igual o mayor categoría y que por tal se apartó de los criterios establecidos; dicha hipótesis no tiene cabida dentro del contenido legal propuesto en la ley 1150 .

Para el profesor Expósito (2013), lopreceptuado en la ley implica que la selección de los contratistas de la administración, se constituye en una formalidad básica para la configuración y correcta ejecución del contrato estatal como pilar fundamental de la figura, ya que el cumplimiento del deber de selección objetiva se concreta mediante la realización de procedimientos que permitan la libre concurrencia de los particulares y garanticen la elección justa e imparcial de la mejor propuesta para los intereses se la entidad, todo con la finalidad de satisfacer el interés general por medio de la continua y eficiente prestación de un servicio denominado público por su alcance y dirección a la comunidad en general, reflejado ya sea en un objeto que directamente afecta a los administrados o en el correcto funcionamiento de la administración, para que ella cumpla su función frente a la colectividad. Entonces, esa afectación final del interés público es la que justifica una regulación concreta y estricta de la forma de escoger al responsable de llevar acabo la labor encomendada a la entidad estatal.(p. 60).

Ahora bien, la ley establece unas formas de habilitación y ponderación para cada proceso de selección, de modo tal que siempre que la selección del contratista se efectúe, atendiendo esos factores objetivos, previamente delimitados y definidos al detalle, en los estudios previos y pliegos de condiciones, sin salirse de los límites establecidos en el artículo 5 de la ley 1150, debe concluirse que el deber de selección objetiva se acató. Por el 
contrario, cuando se demuestre que la selección obedeció a factores subjetivos o que, pese haberse fijado criterios objetivos de selección, la escogencia no se efectúo con fundamento en ellos, puede concluirse que se desconoció tal deber.

Con lo esbozado hecho en la anteriores líneas, será más acertado pensar en que, la selección objetiva es un deber, contenido en una regla irrestricta de obligatorio cumplimiento, que no admite ponderación alguna, bajo ningún caso particular, que se cumple o no se cumple y que en esa medida cualquier regla que disponga criterios distintos a los contenidos en dicha regla está condenada a desaparecer y que para evitar esas situaciones el legislador, teniendo en cuenta que la selección objetiva es una regla, podría establecer reglas de excepción a la misma, de suerte que con ello prevalecerá la vigencia de una y otra.

En la aplicación del deber de selección objetiva, no podríamos hablar de la existencia de casos difíciles o de penumbra que ameriten hacer elucubraciones para lograr desenmarañar el sentido que tiene aplicar o no la selección objetiva; por el contrario como se encuentra concebida dicha regla, está estructurada para los casos fáciles, es decir que contiene un enunciado normativo cerrado que se debe aplicar a todos los procedimientos de selección de contratistas, por ello solo puede entenderse que la capacidad jurídica y la capacidad financiera son requisitos habilitantes en los procesos de selección y que no otorgan puntaje alguno, lo que se deprende del contenido literal de la disposición normativa; situación que fundamenta el carácter particular y rígido de la regla de la selección objetiva, que implican su obligatoriedad, por ser un mandato de hacer $y$ confeccionar reglas objetivas y de prohibir comportamientos subjetivos, supuesto de hecho que se ser incumplido deviene en unas consecuencias jurídicas: la selección objetiva está concebida para que se cumpla el deber consagrado en ellas, ni más, ni menos.

\subsection{Implicaciones de la selección objetiva por su naturaleza dual.}


Luego de la dura disertación entre la selección objetiva vista como principio y regla, se hace necesario ahora, hacer una mirada de las implicaciones que puede tener la selección objetiva, respecto a la naturaleza de responsabilidad múltiple, por tratarse de una función de la contratación estatal que se desarrolla en el ámbito de la actividad administrativa, y que conlleva responsabilidad penal, fiscal y disciplinaria para la entidad y los funcionarios.

\subsubsection{La selección objetiva en el ámbito administrativo.}

En este escenario, se debe tener presente que los procedimientos de selección de contratistas como se ha dicho ampliamente, corresponden a una verdadera actuación administrativa del Estado y como tal, le son aplicables los principios constitucionales contenidos en el artículo 209 de la Carta. Ahora bien, no se puedeperder de vista que en esencia la actuación administrativa conlleva una relación contractual, sin embargo, por la amplitud del contenido de la teoría del contrato, solo se hará una breve relación de los requisitos de la voluntad y el principio de libertad e igualdad de dicha relación contractual, temas pertinentes a este trabajo, en cuanto la selección objetiva debe de estar fundamentada en estos principios.

En palabras de Santofimio los contratos estatales, por regla general, son contratos solemnes, lo cual a la luz del artículo 1500 del Código Civil, significa que están sujetos a la observancia de ciertas formalidades especiales de manera que sin ellas no producen ningún efecto jurídico. (Santofimio, 2002).

Respecto al contrato, el código civil colombiano establece que: "el contrato o convención es un acto por el cual una parte se obliga para con otras a dar, hacer o no hacer alguna cosa". (Artículo 1495, CCC). De este mandato legal, surge el presupuesto de la voluntad contractual, que permite que el contrato nazca y sea válida, sin embargo, esto es posible cuando la voluntad cumpla con los siguientes requisitos: a) que cada parte entienda obligarse y b) un consentimiento serio, es decir, libre de la simulación y del fraude a la ley. 
Lo anterior implica que exista una forma expresa, como oposición a la simulación; y c) que cada parte se obligue dentro de la legalidad, en contraposición al frade a la ley.

De lo establecido en el código civil, se considera que frente al primer requisito no existe mayor dificultad, por cuanto las partes mediante un acto consiente, libre y voluntario deciden comprometerse a través de la relación contractual; de igual forma, sucede con el tercero, porque en el evento que el contrato se realice por fuera de la ley, se estaría actuando en el campo de lo legal y las misma ley entraría a sancionar esta conducta. Sin embargo, respecto a la teoría de la simulación, si aparecen dificultades tanto para el derecho como para la misma relación contractual, en virtud que es la misma voluntad de las partes, la que se asocia para consentir o para simular.

Para el profesor Ospina (1994), la simulación “es la discordancia entre la voluntad real y su declaración y se da en el concierto de dos o más personas para fingir una convención ante el público con el fin de que esta no produzca, en todo o en parte los efectos aparentados, o en disfrazar mediante una declaración pública una convención realmente celebrada con el ropaje de otro negocio diferente; o camuflar a una de las partes verdaderas con la interposición de un tercero". (p. 108).

Respecto al principio de igualdad y la libertad fundamento jurídico del contrato, Rodríguez Yong (2013), considera que hacen parte de la autonomía de la voluntad y consiste en la facultad de una persona para decidir si quiere contratar, con quien quiere hacerlo y bajo qué condiciones, sostienen: "Entre las prerrogativas que envuelven la libertad contractual, se encuentran la libertad de contratar o no contratar, libertad de elegir con quien celebrar el contrato, libertad de escoger la forma del contrato, libertad de celebrar el contrato de forma inmediata o de forma progresiva y libertad de establecer el contenido del contrato, entre otros". (p.29).

De la lectura de lo expuesto, se infiere que el contrato se fundamenta en presupuestos filosóficos y sociológicos que operan en el acuerdo de voluntades de las 
partes que se obligan. En palabras de Luis Diez Picazo (1999), “estos presupuestos son de tipo económico, de igualdad y de libertad; son reconocidos y concedidos por la doctrina y la ley, respecto a las partes contratantes, porque a través de ellas se expresa el querer y el consentimiento en el contenido del contrato". (p. 121).

Con fundamento en el presupuesto de economía Soto (2003), “considera que este, está enmarcado en la teoría de la economía liberal, la cual se fundamenta en el lema de “laissez faire, laissez passer, le monde va lui meme” y en la idea de que las leyes del mercado, el egoísmo y la competencia individual, (...) expresa, este presupuesto no tiene mucha relevancia en la solemnidad contractual actual'. Respecto alprincipio de igualdad de las partes, "este se base en la idea suprema e ineludible de la igualdad, como posibilidad sustancial que tienen las personas contratantes, en atención a que el contrato es el mejor medio de acuerdo para arreglar los intereses privados, por ser el acto más común de los contratantes que se encuentran en igualdad de condiciones para expresar las intenciones de la negociación, lo que se supone un arreglo entre iguales”. (p. 567).

Con respecto a los principios de libertad e igualdad como pilares de la contratación estatal, Suescun J (2005), dice que fueron altamente cuestionados a finales del Siglo XIX y comienzos del Siglo XX,"Pues los comerciantes de esta época ya no tendrían la facultad de imponer sus propias reglas comerciales”. (p.33).

Como se viene afirmando, la presencia de formalidades en la función contractual implica la solemnidad del contrato estatal, que es lo que marca la gran diferencia con el contrato en el derecho privado. A este respecto, el Consejo de Estadodice que "dichos contratos por disposición legal son solemnes, puesto que están sujetos a la observancia de ciertas formalidades especiales, de manera que sin ellas no producen ningún efecto jurídico”(Consejo de Estado, Sala de Contencioso Administrativo, sentencia del 12 de diciembre de 2001, MP. Enrique José Arboleda, Exp. 16.886). 
Así las cosas, la selección objetiva del contratista, mediante el uso de los procedimientos de selección previstos por el legislador, hace parte de las formalidades que deben tenerse en cuenta para la materialización inmaculada del negocio jurídico; Expósito (2013),dice que la doctrina, al referirse a las modalidades de selección de contratistas, cuya finalidad es dar efectividad al deber de selección objetiva, de tal manera que se garantice la escogencia de la oferta más favorable a los intereses de la entidad, con las formalidades necesarias; al paso el autor resalta que, todo lo anterior implica que la selección de los contratistas de la administración se constituye en una formalidad básica para la configuración y correcta ejecución del contrato estatal como pilar fundamental de la figura.

Con fundamento en lo anterior, tendríamos dos aristas diferentes. La primera de ellas sería que al considerar la selección objetiva como un principio de la contratación estatal, desde la perspectiva que dicho principio puede ser cumplido en la mayor medida de lo posible conforme a las posibilidades fácticas y jurídicas existentes, corriendo el riesgo de aceptar que en determinado momento, apartarse de los criterios de selección objetiva, se tenga un argumento legal y constitucional válido, posición que implica un enorme riesgo frente a la seguridad jurídica que debe pregonarse en la materia.Ahora bien si eso fuese así, desde la formación del acto jurídico contractual, no podría pregonarse la existencia de una causal de nulidad o invalidación del mismo.

En ese sentido entendemos que es másapropiado considerar a la selección objetiva, como una verdadera regla, que implica el cumplir un deber legal y contractual solemne que bajo ninguna circunstancia puede ser inaplicada, al punto que su inobservancia conllevaría la invalidación del contrato estatal por pesar sobre él, una causal de nulidad. Sobre el particular observemos que el Consejo de Estado ha sido enfático en señalar que al sustraerse al deber de selección objetiva implica la nulidad del contrato estatal, por existir además la prohibición legal que obliga a los funcionarios públicos y las entidades del Estado,a aplicar siempre los procedimientos de selección objetiva, cuando expresa: 
Con fundamento en las anteriores precisiones en punto al catálogo de causales de nulidad absoluta de los contratos estatales en el ordenamiento jurídico colombiano y visto y explicado como está, suficientemente, en el presente proveído, que al tratarse el contrato número 002 de 1994, celebrado entre la Junta Administradora Seccional de Deportes de Bogotá y Coinverpro Ltda., de un negocio jurídico de concesión y que la selección del contratista en este caso no se llevó a cabo siguiendo el procedimiento administrativo de licitación que para la escogencia de concesionarios demanda la normatividad contenida en la Ley 80 , queda evidenciado que el contrato estatal en mención adolece de uno de los elementos necesarios para su validez, en cuanto no se observó el procedimiento que la ley imponía para la selección del contratista; a su turno, tal circunstancia da lugar a la configuración de la causal de nulidad prevista en el artículo 6 del Código Civil -incorporada en el Estatuto Contractual del Estado por virtud de lo normado en el inciso primero del artículo 44 de la Ley 80, según se explicó-, consistente en la vulneración de normas legales de orden público, en este caso, de las que condicionan el procedimiento de formación del contrato y, concretamente, de la prohibición general que contiene el numeral $8^{\circ}$ del artículo 24 de la citada Ley 80, en el sentido de que las autoridades tienen prohibido eludir los procedimientos de selección objetiva de contratistas (Consejo de Estado, Sección Tercera, sentencia del 18 de septiembre de 2010, MP. Mauricio Fajardo Gómez, Radicación: 25000-23-26-000-1994-00071-01(14390).

Visto el panorama anterior, se puede concluirse que se hace relevante en el ámbito de la validez delacontratación estatal, darle un tratamiento de principio o regla a la selección objetiva, pues la aplicación o no de estos presupuestos, implica consecuencias negativas y por ende la existencia de causal de nulidad en la formación del acto jurídico generador de las obligaciones.

\subsubsection{La selección objetiva en el ámbito de la responsabilidad penal.}

Para el profesor Rico Puerta (2012), el contenido penal de la responsabilidad derivada de las acciones u omisiones antijurídicas en la gestión contractual, encuentra diversas consagraciones, tales como los articulo 6 y 122 a 131 de la ConstituciónPolítica; 25, 51, 52, 53, 54, 55, 57, 58, 59, 64 y 66 de la ley 80 de 1993; el artículo 1 del Código Contencioso Administrativo y la ley 190 de 1995, articulo 17 a 32 entre otros.Mientras que para Palacio Juan (2010), la responsabilidad penal, se presenta cuando el funcionario ha realizado una conducta que se tiene tipificada como delito en el código penal.

En el ámbitode la responsabilidad penal, considerar la selección objetiva como un principio, o una regla o deber, no tiene implicaciones trascendentales; sin embargo, si las 
tiene cuando enejercicio de la selección objetiva, se trasgrede los tipos penalescontenidos en los artículos 409 y 410 del código penal. Son dos las conductas que se pueden vulnerar, en el ámbito de lo penal: el interés indebido en la celebración del contrato y el contrato sin cumplimiento de los requisitos legales.

De igual forma, se puede infringir la norma cuando no se da aplicación a las reglas establecidas en el artículo 5 de la ley 1150, esto es, cuando existen factores subjetivos de afecto o interés, entonces, se puede configurar uninterés indebido en la celebración del contrato; a su paso, si se omitiere alguno de los requisitos establecidos en dicha norma para efectos de seleccionar la mejor oferta, podría configurarse la celebración de un contrato sin cumplimiento de los requisitos legales.

Esta conducta es reprochada al servidor público, y consiste en el hecho de que exista un interese en provecho propio o de un tercero de cualquier clase de contrato u operación en que deba intervenir en razón de su cargo o de sus funciones. Ese interés se penaliza en la medida en que se han dado manifestaciones externas del mismo por parte del servidor, y que se traducen como el abandono del deber de imparcialidad o de trasparencia en la gestión contractual. El tipo penal no sanciona los simples pensamientos, personalidad o tendencias del servidor, sino el interés indebido que se manifiesta externamente a través de actuaciones concretas del servidor público. (Matallana Ernesto, 2009).

Ahora bien, para Chacón Antonio (2013),el dispositivo legal tiene una norma penal en blanco, cuya integración se cumple con el articulado del estatuto contractual, elaborando de esta manera un esfuerzo hermenéutico, hasta alcanzar el propósito del operador judicial.

Con base en lo anterior, puede decirse que,el tipo penal en el que más se ve involucrado un servidor público, cuando se aparta de los postulados contenidos en el deber o el principio de la selección objetiva, será el de la celebración de contratos sin cumplimiento de los requisitos legales, norma que a primera vista contempla lo que se denomina un tipo penal en blanco que requiere de otras normas que expresen claramente el 
deber, obligación o la prohibición en la que se incurre a efectos de encuadrar el comportamiento del actor.

Bajo este escenario,cobraría relevancia el hecho de señalar que la selección objetiva implica un deber o regla que le señala al servidor público como debe actuar, debiendo ser cumplida esa obligación en la forma todo o nada, no en la menor o mayor grado; así por ejemplo, el artículo 5 de la ley 1150 señala la prohibición de que en los procesos para la selección de consultores en ningún caso se puede tener en cuenta el precio ofrecido como factor determinante para la selección del contratista de suerte que, de llegarse a escoger a un consultor con base en el criterio del precio ofertado y sin analizar la experiencia como factor determinante de escogencia, podría estarse ante la celebración de un contrato sin cumplimiento de requisitos legales.

Observemos que en el ejemplo anterior, se hace importante el hecho de considerar la selección objetiva como un deber o regla a la que deben ceñirse los servidores del Estado en el trámite de los procesos contractuales; pues el artículo 5 de la ley 1150, señala una regla que debe ser cumplida en la modalidad todo o nada, cuando expresa que, en los procesos para la selección de consultores en ningún caso se puede tener en cuenta el precio ofrecido como factor determinante para la selección del contratista. Por el contrario, si la selección objetiva fuera considerada como un principio el mandato contenido, no sería tan claro, precioso y contundente, e inclusive bajo una situación determinada en un caso concreto la entidad podría apartarse de su cumplimiento, o podría cumplirlo en la mayor medida de lo posible conforme a las posibilidades fácticas y jurídicas existentes; quedando en entredicho la posible responsabilidad penal que se derivará como consecuencia de un actuar contrario a la norma.

A manera de conclusión, podría decirse que, si bien en principio el considerar la selección objetiva como un principio o como un deber, podría representar una sutileza, dicha manifestación no sería del todo cierta, a nivel teórico, como ya ha quedado decantado 
a lo largo de este trabajo y en la práctica misma ante cada caso concreto, revestiría a unas connotaciones que pueden ser de gran relevancia.

\subsubsection{La selección objetiva en el ámbito de la responsabilidad fiscal.}

Esta conducta de responsabilidad fiscal derivada de la actuación contractual publica, se deduce mediante un proceso de responsabilidad fiscal, definido como el conjunto de actuaciones administrativas adelantadas por las contralorías con el fin de determinar y establecer la responsabilidad de los servidores públicos y de los particulares, cuando en el ejercicio de la gestión fiscal, o con ocasión de ésta, cusen por acción u omisión y en forma dolosa o culposa un daño al patrimonio del Estado. (Rico Puerta, 2012).

Al revisar el Estatuto de Contratación se encuentra que la ley 80 de 1993 no estableció la responsabilidad fiscal para los servidores públicos, ya que solo habla de responsabilidad civil, penal y disciplinaria (art 51), lo que no quiere decir que no pueda ser objeto de la misma, para lo cual hay que remitirnos a la ley 610 de 2000 y usando como enfoque lo que la Corte Constitucional señalo, es decir, que la contratación pública es una herramienta de gestión y en ese sentido el servidor público, al adelantar las actuaciones enmarcadas en las reglas de contratación estatal, ejercen actos propios de la gestión fiscal, y en esa circunstancias puede ser sujeto de la responsabilidad fiscal, que eventualmente se derive de la misma, por daños al patrimonio público producidos dentro de ese proceso contractual (Matallana Ernesto, 2009).

De lo decantado anteriormente, es importante contextualizar la importancia de la selección objetiva en su enfoque dual, con el fin de identificar cual sería la concepción más adecuada que deba darse a este precepto; pues nótese que, la ley 1150 de 2007, al referirse a la adquisición de bienes y servicios de características técnicas uniformes y de común utilización expresa. "En los pliegos de condiciones para las contrataciones cuyo objeto sea la adquisición o suministro de bienes y servicios de características técnicas uniformes y 
común utilización, las entidades estatales incluirán como único factor de evaluación el menor precio ofrecido".(Artículo 5).

En el precepto normativo se impone una regla que involucra un deber que es de obligatorio cumplimiento por parte de los servidores públicos, en tal sentido la regla indica que en ese tipo de procedimientos selectivos, el único factor que debe tenerse en cuenta para la comparación de las ofertas es el menor precio ofrecido; regla que no puede ser aplicada en la mayor medida de lo posible conforme a las posibilidades fácticas o jurídicas existentes como si se tratara de la aplicación de un principio; de suerte que quien en un proceso de selección de bienes y servicios de características técnicas uniformes y de común utilización tenga en cuenta como factor de escogencia el mayor precio o la experiencia del contratista o las condiciones de calidad de los bines y servicios y no se limite a la aplicación del único criterio objetivo considerado por la norma, cual es el menor precio ofertado, incurrirá en la responsabilidad que de ello se derive, responsabilidad que podría llegar a tener consecuencias de carácter fiscal, en la medida en que no se opte por la escogencia de la oferta que contenga el menor precio ofertado y por el contrario se escogiere la oferta de mayor valor atendiendo a consideraciones distintas a las contempladas en el precepto de selección objetiva.

Del escenario planteado, puede refirmarse la conveniencia que representa en la práctica, considerar a la selección objetiva como una regla impuesta por el legislador que debe ser cumplida en todo momento y no como un principio que apenas guía el andar se los procesos de selección de contratistas, sin que exista la posibilidad de establecer responsabilidad fiscal respecto al servidor público que por acción u omisión dejo de lado el precepto legal.

\subsubsection{La selección objetiva en el ámbito disciplinario.}

Para empezar, debo decir que mucho se ha dicho sobre la naturaleza del derecho disciplinario, Brito (2012) considera que la misma puede ser de carácter penal, como lo 
han considerado algunos; de naturaleza administrativa, como lo clasifican otros; o puede constituir un derecho autónomo. Lo cierto es que, el régimen disciplinario busca aplicar los correctivos necesarios para aderezar el actuar del funcionario, cuando ello es posible, restablecer la marcha del servicio mediante la desvinculación del agente si no existe otra solución legal. La entidad debe exigir a sus funcionarios el estricto cumplimiento de la función a su cargo y por tanto, está dotada de la facultad de sancionarlos ante la existencia de alguna falta que perturbe la prestación del servicio a su cargo o exigirles responsabilidad por las conductas que se salgan del marco de su gestiónpública.(Palacio Juan, 2014, p.643).

El escenario del derecho disciplinario es donde más tiene incidencia el hecho de considerar a la selección objetiva como un principio o como una regla, ya que la sustracción de dicho postulado puede configurar la comisión de una falta disciplinaria. Recordemos que como lo expone Osa (2009), la responsabilidad de tipo disciplinario nace del desconocimiento por parte del agente público de una obligación que se le ha impuesto previamente, es decir que, existe una serie deberes que el servidor público ha de observar, so pena de incurrir en la comisión del ilícito disciplinario.

La definición de falta disciplinaria se encuentra contenida en el artículo 23 de la ley 734 de 2002; para SánchezYate, y Díaz, (2009) se entiende por falta disciplinaria toda conducta que comporte incumplimiento de deberes, extralimitación en el ejercicio de derechos y funciones, prohibiciones y violación del régimen de inhabilidades, incompatibilidades, impedimentos y conflicto de intereses, siempre que no se actué amparado por alguna de las causales de ausencia de responsabilidad contenidas en la misma ley.

La normatividad disciplinaria vigente, contiene un listado expreso y taxativo de faltas disciplinarias gravísimas, que se encuentra contenido en el artículo 48 de la ley 734 de 2002, dentro de ese listado es importante referirnos a la falta disciplinaria gravísima que contiene el numeral 31 que a la letra dice: "participar en la etapa precontractual, o en la actividad contractual, en detrimento del patrimonio público, o con desconocimiento de los principios que regulan la contratación estatal y la función administrativa contemplados en 
la constitución y en la ley". (Procuraduría General de la Nación, Código Disciplinario Único, 2011).

Del postulado legal, debe decirse que involucra dos aspectos: el primero de ellos al cual no nos vamos a referir por no ostentar la pertinencia adecuada para el tema que se está tratando, corresponde a la intervención del funcionario en la actividad precontractual o contractual en detrimento del patrimonio público. En tanto que el segundo componente de la norma hace relación directa con el tema que es materia de investigación y es donde cobra gran relevancia, identificar al precepto de la selección objetiva como un principio o como una regla o deber que deben cumplir las entidades del Estado en la selección de sus contratistas. Es decir que constituye una falta gravísima participar en la actividad contractual con desconocimiento de los principios que regulan la contratación estatal y la función administrativa del Estado.

Ahora bien, como se desprende del artículo 23 de la ley 734 de 2002, es falta disciplinariala incursión en conductas que impliquen el incumplimiento de deberes que se encuentren señalados en la normatividad actual vigente; sin embargo, se debe precisar que el legislador solo contemplo taxativamente las faltas disciplinarias gravísimas, de suerte que la configuración de faltas disciplinarias graves o leves, se encuentra al arbitrio de quien ejerce la acción disciplinaria, conforme los parámetros establecidos en la ley, existiendo una multiplicidad de deberes contenidos en distintas normas que pueden llegar a ser incumplidos en determinado momento, por uno de los agentes del Estado.

La importancia de diferenciar la selección objetiva como un principio o como una regla que contiene un deber de obligatorio cumplimiento, tiene sus consecuencias en el ámbito disciplinario, en la media en que la sanciones que se aplican ante la comisión de una falta gravísima y la configuración de una falta grave por el incumplimiento de un deber son ostensiblemente distintas. Conforme lo dispone el artículo 42 de la ley 734 de 2002, las faltas disciplinarias se clasifican en Gravísimas, Graves y Leves; las primeras como ya se dijo están taxativamente enunciadas en el artículo 48 de la citada disposición y en el 
numeral 31 de la mismas se encuentra contenida la falta disciplinaria que surge de la participación en los procesos precontractuales y contractuales del estado con desconocimiento de los principios que orientan la contratación estatal y la función administrativa del Estado.

Para la fijación de las faltas graves y leves quien ejerza la acción deberá entre otros, aplicar los criterios contenidos en el artículo 43 de la ley 734 de 2002. A su turno el artículo 44 de la ley 734 de 2002 establece las sanciones que han imponerse ante la comisión de una falta, y para el caso de las faltas gravísimas, dolosos o realizadas con culpa gravísima impone de entrada la destitución e inhabilidad general, que puede ser desde 10 hasta 20 años e inclusive permanente cuando afecta el patrimonio del Estado; para las demás faltas disciplinarias y atendiendo a la modalidad de comisión, se imponen sanciones que van desde la amonestación en la hoja de vida, pasando por la suspensión e inhabilidad especial hasta por el término de un año.

Si la selección objetiva fuere considera un principio de la contratación estatal, el fundamento legal del mismo estaría dado por el artículo 5 de la ley 1150, y para efectos de configurar una falta disciplinaria sobre la violación a dicho precepto, no bastaría con enunciarse su violación, pues sobre la configuración de faltas disciplinarias sustentadas en violación a principios, laCorte Constitucional ha establecido unos criterios que posibilitan interpretar la norma, al expresar:

Para la configuración de una falta disciplinaria, se deben describir en términos absolutos, precisos e incondicionales las conductas que impliquen la existencia de una obligación, deber, prohibición, incompatibilidad o inhabilidad que impidan que el juzgamiento de una persona quede sometido al arbitrio del funcionario investigador. Exigencia que tratándose de los principios no es posible acreditar, pues éstos siempre se expresan a través de mandatos generalizados que contribuyen a la unificación de las distintas instituciones jurídicas que afianzan el sistema normativo. Ahora bien, los principios como norma jurídica también pueden ser objeto de complementación mediante la integración jurídica de su contenido normativo, ya sea a través de disposiciones constitucionales de aplicación directa o de normas de rango legal (o en términos generales: reglas), que permitan concretar de manera clara e inequívoca, los conductas prohibidas en materia disciplinaria. Se trata de acudir al empleo de la técnica de remisión del tipo disciplinario en blanco o abierto que exige para la constitucionalidad de la 
descripción de una infracción disciplinaria, la definición de un contenido normativo específico mínimo que garantice a los destinatarios de la norma, protección contra la aplicación arbitraria de la misma. (Corte Constitucional, sentencia C-818 de 2005. MP. Rodrigo Escobar Gil).

Es decir, que al tomar a la selección objetiva como un principio, para configurar la falta disciplinaria gravísima contemplada en el numeral 31 del artículo 48 de la ley 734 de 2002, tendrá que determinarse que la vulneración al principio de selección objetiva tiene un carácter concreto y especifico a través de la complementación de ese precepto normativo, con una regla de manera precisa, concreta y específica, describa con claridadcuál es el mandato, el deber, o la prohibición que fue desconocido por el servidor público.Si el ejercicio anterior es realizado con éxito, la sanción que resultaría de la infracción al principio de selección objetiva seria la destitución e inhabilidad general por el término que se determine en el respectivo fallo.

Sin embargo debe señalarse que dicha posición no es compartida por el suscrito, toda vez que como ampliamente se ha dicho a través de esta investigación, el legislador al referirse a la selección objetiva no le otorgo específicamente el carácter de principio, por el contrario el antecedente previsto en el derogado artículo 29 de la ley 80, impuso el deber de la selección objetiva; ahora bien en la sentencia C-818 de 2005, la Corte ejemplifico los principios de la contratación, refiriéndose a los contenidos en los artículos 23 al 26 de la ley 80 de 1993, es decir, trasparencia, economía y responsabilidad, de suerte que mal haría el operador disciplinario, en considerar que la selección objetiva impera y opera como una norma autónoma que contiene un principio, para fundamentar en ella de manera directa un fallo disciplinario sancionatorio, con la consecuencia que implica la gravedad de la sanción a imponer que sería la destitución e inhabilidad general.

Pese a lo anterior se debe señalar que, si se le considera a la selección objetiva como una regla o un deber que deben cumplir las entidades del Estado en la actividad contractual, el panorama nos ofrece dos posibilidades distintas de configurar la falta disciplinaria, con consecuencias jurídicas distintas. La primera de ellas se mantiene en la falta gravísima tipificada en el artículo 48 numeral 31 de la ley 734. Ramírez S(2012), considera que podrá 
imputarse responsabilidad disciplinaria a un servidor público por violación a uno de los principios que rigen la contratación estatal, siempre y cuando este tenga un desarrollo normativo claro, por ejemplo, el principio de trasparencia contempla varios aspectos, entre otros la escogencia del contratista mediante concurso, salvo determinadas excepciones, por lo tanto, la omisión de la licitación podrá considerarse como una violación a este principio.

Así las cosas, puede imputarse la responsabilidad disciplinaria por la violación al principio de trasparencia contenido en el artículo 23 de la ley 80, por incumplimiento de las reglas contenidas y desarrolladas en el precepto normativo de la selección objetiva contemplado en el artículo 5 de la ley 1150, que considera que:"para las contrataciones cuyo objeto sea la adquisición o suministro de bienes y servicios de características técnicas uniformes y común utilización, las entidades estatales incluirán como único factor de evaluación el menor precio ofrecido”.Regla que puede ser vulnerada si una entidad contempla otro factor distinto al menor precio para seleccionar a un proponente en un proceso de adquisición de bienes y servicios de características técnicas uniformes y de común utilización.

De suerte que la sanción a imponer seria la destitución e inhabilidad general; sin embargo, nótese que en el ejemplo la selección objetiva opera como una regla que desarrolla el principio de trasparencia, regla que de manera clara y concreta establece la obligación de las entidades de incluir como único factor de evaluación en esta clase de proceso el menor precio, de suerte que la imputación, seguiría las reglas contempladas por la Corte Constitucional, si se dijera que, el principio de trasparencia indica que la compra de bienes de características técnicas uniformes y de común utilización, debe tramitarse a través de una selección abreviada por subasta inversa y dentro de dicho procedimiento el único factor que determina la escogencia del contratista es el menor precio. De moto tal que, se configura la falta disciplinaria con sustento en un principio que es, el de trasparencia, pero desarrollado de manera complementaria clara, concreta y precisa por el deber se selección objetiva contenido en el artículo 5 de la ley 1150. 
La otra posibilidad que ofrece el hecho de considerar la selección objetiva como una regla, se daría al configurar una falta disciplinaría, bajo la perspectiva de que los parámetros contemplados en el artículo 5 de la ley 1150, son reglas y deberes autónomos de obligatorio cumplimiento, previstos por el legislador en cabeza de todas la entidades del Estado que implican su obediencia por parte de los funcionarios que intervienen en los procesos de selección de contratistas; de modo que, si en un proceso de selección de bienes de características técnicas uniformes y de común utilización, se estableció como criterio de selección uno distinto al menor valor ofrecido; podría configurarse la existencia de una falta disciplinaria grave, en los términos del artículo 50 de la ley 734, por el incumplimiento del deber de selección objetiva; lo que implicaría una sanción disciplinaría distinta, cual es la suspensión e inhabilidad especial que oscilaría entre uno y doce meses.

Visto lo anterior, es evidente que considerar la selección objetiva como un principio o una regla, tendría unas implicaciones importantes en el campo de la responsabilidad disciplinaría y las sanciones o consecuencias jurídicas que se derivan de la misma. Situación que se genera por la imposibilidad de derivar responsabilidad disciplinaría de manera directa y autónoma con base en un principio. Para Ramírez S. (2012), atendiendo a los planteamientos dispuestos por la Corte Constitucional, cuyo único objetivo, es que el operador jurídico no realice una subsunción normativa arbitraria de cualquier hecho, como una violación de un principio de la contratación, cuando puede no constituir una irregularidad, o siéndolo enmarcarse en un tipo disciplinario de menor entidad. Es decir, se limitan los alcances de esta norma para impedir que subjetivamente se amplifique y haga extensiva a cualquier conducta que en apariencia se aparte de los formalismos de la contratación estatal. 


\section{CONCLUSIONES}

Del análisis realizado en la investigación se puede concluir que la doctrina y la jurisprudencia permiten hacer claridad en torno a los conceptos de principios y regla, aun partiendo de la tendencia más generalizada de distinción, se puede reconocer que ambos conceptos son concebidos como normas jurídicas dentro de un sistema jurídico.Sin embargo, se pueden establecer una serie de diferencias conceptuales que quizá en la práctica constituyan lo mismo.

Se concluye que tanto losprincipioscomo las reglas son normas jurídicasque hacen parte del ordenamiento jurídico. Los principios son mandatos de carácter general,aplicables a generalidad de casos, en tanto son directrices orientadoras utilizadas en casos difíciles, oscuros o de penumbra, como soporte del sistema de reglas y criterio de interpretación de las mismas, para dar claridad y ayuda interpretativa, mientras que lasreglas están destinadas a operar en lo que se ha llamado los casos fáciles, frente a enunciados normativos cerrados, porque para su aplicación solo basta con apegarse a su sentido literal.Así las cosas, losconflictos surgidos entre principios se pueden resolver por medio de la ponderación, lo cual marca clara diferencia en el campo de la aplicación, con la regla, en virtud que esta se aplica o no se aplica, y en caso de colisión entre dos reglas una de ella siempre prevalecerá.

Otra diferencia está dada por el carácter rígido, particular y estático de las reglas y la universalidad, la movilidad y versatilidad de los principiosque lo hace adaptablea casos concretos.Lasreglas son obligatorias, en cuanto se aplican o no se aplican; mientras que los principios tienen una propiedad de peso y se encuentran sujetos a la ponderación, de lo que se deduce el carácter obligatorio de las reglas y el no obligatorio de los principios.

Lasreglas son mandatos de hacer, de permitir, o de prohibir que generalmente se estructuran por unos supuestos de hecho y unas consecuencias jurídicas, se encuentran en el mudo del deber ser, son establecidas para que se cumpla lo contenido en ellas, ni más ni menos. En tanto que los principios, son normas que ordenan que algo sea realizado en la 
mayor medida de lo posible, dentro de las posibilidades jurídicas y reales existentes, de suerte que se convierten en mandatos de optimización, al punto que en un determinado caso pueden ser cumplidos en diferente grado.

En Colombia la jurisprudencia y la doctrina, han aceptado la teoría que sustenta que el principio es una norma jurídica y como tal, adquiere una carácter de obligatorio cumplimiento, en todos las actuaciones administrativas y judiciales y fundamento del respecto y garantía de los derechos de las personas, por este motivo, es deber legal para las autoridades y las entidades y servidores públicos acatarlos.

En síntesis, se considera que el principio recibe diversas acepciones y que no es posible determinar con certeza, los limites conceptuales con la regla. Sin embargo, lo importante es saber que hacen parte del escenario jurídico enriqueciendo la doctrina, la jurisprudencia, los debates académicos y la práctica judicial, permitiendo una mayor efectividad en los procesos y las providencias en pro de la justicia y de los ciudadanos, que requieren de ella.

Respecto a la selección objetiva, no existe claridad meridiana frente a la conceptualización y tratamiento jurídico que se hace del término, debido a que tanto la doctrina como la jurisprudencia se refieren a ella, de acuerdo a las circunstancias donde se desarrolle. Así por ejemplo, la norma establece que la selección objetiva es una regla, cerrando la posibilidad de ser interpretada y aplicada como principio, en tanto, fija parámetros de regulación que no son discrecionales, sino de obligatorio cumplimiento. Es decir, no existe la posibilidad para que la entidad, de acuerdo a las posibilidades fácticas de un caso en concreto, argumente que se aplicó un principio ante uno de igual o mayor categoría y que por tal se apartó de los criterios establecidos, en la selección objetiva;esta hipótesis es descartada por la ley 1150.

La ley 80 de 1993, considera que la selección objetiva del contratista es aquella en la cual se escoge el procedimiento más favorable a la entidad y a los fines que ella persigue, 
sin tener en consideración factores de afecto o de interés y motivaciones subjetiva. Mientras que la ley 1150 de 2007 considera que es objetiva la selección en la cual la escogencia se haga al ofrecimiento más favorable a la entidad y a los fines que ella busca, sin tener en consideración factores de afecto o de interés y, en general cualquier clase de motivación subjetiva. En consecuencia, los factores de escogencia y calificación que establezcan las entidades en los pliegos de condiciones y sus equivalentes tendrán en cuenta los criterios señalados en la citada disposición.

Para la doctrina y la ley, es más acertado pensar que la selección objetiva es un deber, contenido en una regla irrestricta de obligatorio cumplimiento, que no admite ponderación alguna, bajo ningún caso particular, que se cumple o no se cumple y que en esa medida, otra regla que disponga criterios distintos debedesaparecer.

Para la jurisprudencia, la selección objetiva tiene el carácter de deber y de principio orientador y por lo tanto, donde el deber se constituye en norma jurídica en la medida que debe ser acatada por todas la entidades del Estado en los procedimientos de selección, porque obedece a un acto reglado de la administración ypor esta razón descarta la teoría deentender la selección objetiva solo como principio, en tanto, no es un criterio abstracto y general que caracteriza a los principios.

También determina la jurisprudencia, que es una regla de conducta de la actividad contractual, pero al mismotiempo,un principio que orienta los procesos de selección tanto de licitación pública y de contratación directa, apuntado a la escogencia de la oferta más ventajosa para los intereses colectivos perseguidos en la contratación estatal, guiada por los principios de selección objetiva, economía y trasparencia, entre otros.

La jurisprudencia ha considerado que la selección objetivaes tratada como un principio de la contratación estatal, que involucra reglasy deberes para la administración, pero no hace ninguna precisión o distinción entre si es principio o regla, al afirmar que la escogencia o selección objetiva de los contratistas constituye uno de los principales deberes 
de todos los responsables de la contratación estatal, en tanto, la selección objetiva es un deber-regla de conducta- en la actividad contractual; un principio que orienta los procesos de selección.

A pesar que la doctrina y la jurisprudencia aceptan indistintamente la dualidad de la selección objetiva, se considera que para que pueda existir un fundamento legal al respecto, se debe sustentar primero, en una relación contractual y dos, en los preceptos legales. Es decir, que para poder hacer imputaciones de responsabilidad penal, fiscal o disciplinaria por la acción o la omisión al servidor público, es necesario concebir la selección objetiva como un mandato legal establecido para una relación contractual determinada, contrario sensu, no es posible tal imputación debido al carácter abstracto e indeterminado del principio.

Se hace evidente, que la jurisprudencia respecto a la naturaleza de la selección objetiva,aceptan dos posiciones. De una parte, apuntan a que la sección objetiva obedece a un verdadero principio de la contratación estatal, en tanto, la Constitución de 1991, le otorgó a la selección objetiva el carácter de principio constitucional, al considerar que la escogencia de los contratistas, se constituye en principioque satisface el interés general y los intereses particulares de la entidad, como fundamento esencial de la función administrativa del Estado Social de Derecho.

Se observar que los esfuerzos hechos por la doctrina y la jurisprudencia no han sido suficientes para concebir a la selección objetiva como un principio o como una regla, en tanto, ambas reconocen que pertenece a la categoría de los principios, pero al mismo tiempo tienen el carácter de regla y de deber. Así las cosas, la selección objetiva es un concepto jurídico indeterminado, y como tal debe ser precisadapara cada situación en particular y obedece exclusivamente a una decisión neutral de una administración imparcial, sujeta única y exclusivamente al interés general.

Con la expedición de la ley 1150 de 2007, la selección objetiva adquiere una connotación que la lleva más al campo de la regla y del deber que al campo del principio, 
ya que del texto del artículo 5, surgen reglas y prohibiciones claras precisas y de obligatorio cumplimiento, como cuando se establece que para la adquisición de bienes y servicios de características técnicas uniformes y de común utilización las entidades estatales incluirán como único factor de evaluación el menor precio ofrecido; o como cuando se dice que En ningún caso se podrá incluir el precio, como factor de escogencia para la selección de consultores.

En la medida en que la selección objetiva sea mirada como una regla que implica un deber de obligatorio cumplimiento, se podrá con mayor precisión, atribuir consecuencias a su aplicación o inaplicación, desde el punto de vista administrativo en la formación del contrato y desde el punto de vista de las consecuencias que deriven el campo del derecho disciplinario.

En el escenario del derecho disciplinario, es donde mayor connotación puede llegar a representar el hecho de determinar si la selección objetiva es un principio o una regla que involucra un deber, pues nótese que si se mira como un principio, la inobservancia de sus postulados nos llevan a la configuración de una falta disciplinaria Gravísima, contemplada en el Numeral 31 del Artículo 48 de la ley 734, para cuya imputación se requerirá que dicho principio se desarrolle en otras normas de carácter legal que hayan sido infringidas, de suerte que no podrá imputarse la conducta con fundamento en la violación directa de un principio.

Si la selección objetiva es mirada como una regla, que implica un deber de obligatorio cumplimiento, en el ámbito del derecho disciplinario será más fácil la imputación de la conducta con base en la violación a un deber, con fundamento directo en el artículo 5 de la ley 1150, norma que no requeriría de ningún desarrollo normativo distinto de su propio contenido. Sin embargo si la selección Objetiva es tomada como un deber, la falta disciplinaria se reduce de gravísima a grave, como quiera que no se viole un principio,sino un deber más, de los muchos atribuidos a los servidores públicos. 


\section{REFERENCIA}

1. AlEXY, R. (2007). Teoría de la Argumentación Jurídica. Madrid. Centro de Estudios Políticos y Constitucionales.

2. ALEXY,R. (2010).Teoría de los Derechos Fundamentales. Madrid. Segunda edición en castellano Centro de Estudios Políticos y Constitucionales.

3. ALEXY,R. (2003).Tres Escritos Sobre derechos fundamentales y teoría de los principios. Traducción de Carlos Bernal Pulido, Bogotá. Primera edición, Universidad Externado de Colombia.

4. ARANGO Rodolfo (2005). El concepto de Derechos Fundamentales. Bogotá, Editorial LEGIS.

5. ARBOLEDA Enrique (2012). Comentarios al Nuevo Código de Procedimiento Administrativo y de lo Contencioso Administrativo. Bogotá, Segunda Edición. Editorial Legis.

6. ARTETA, Luis (2011).La Interpretación de las Normas Jurídicas. Bogotá, Editorial Temis.

7. ATEHORTUA, Carlos (2010).Contratación de empresas Estatales en el Sector de los Servicios Públicos; Temas en Contratos Estatales. Bogotá. Editorial, Biblioteca Jurídica Dike.

8. ATIENZA, M. y RUIZ J. (1991).Las Piezas del Derecho; Teoría de los enunciados Jurídicos. Barcelona, Editorial Ariel S.A.

9. BERNAL Pulido, Carlos (2005).El principio de Proporcionalidad y Los Derechos Fundamentales. Madrid. Segunda edición en castellano Centro de Estudios Políticos y Constitucionales.

10. BERNAL Pulido, Carlos (2008). El Constitucionalismo al debate. Bogotá, Universidad Externado de Colombia.

11. BENAVIDES, José Luis, (2007). El Contrato Estatal, entre el Derecho Público y el Privado. Bogotá, Segunda Edición Universidad Externado de Colombia.

12. BENAVIDES, José Luis (2014). Temas de Derecho Administrativo No. 5. Contratos Públicos Estudios. Bogotá, Primera Edicion. Universidad Externado de Colombia. 
13. BOBBIO, Norberto (1987). Teoría general del Derecho. Bogotá. Temis.

14. BOHÓRQUEZ,B. (2008).Enciclopedia Jurídica de Colombia. Tomo VI, Bogotá, Editorial, Editora Jurídica Nacional.

15. BRITO, F, (2010). El Proceso Disciplinario Verbal, Bogotá, Ediciones Nueva Jurídica.

16. BRITO, F, (2012). Régimen Disciplinario, Bogotá, Editorial Legis

17. CASTRO, C; GARCÍA, L; Y MARTÍNEZ, J (2010), La contratación Estatal Teoría General Perspectiva Comparada y Regulación Internacional, Bogotá, Colección de textos de Jurisprudencia Universidad del Rosario.

18. CAMPILLO PARRA, Carlos Enrique (2004). Celebración y ejecución de contratos estatales. Bogotá Primera Edición. Panamericana Formas e impresos S.A.

19. CARBONELL Miguel (2003). Nuevos tiempos para el Constitucionalismo. En Carbonell, Miguel. (Coordinador), Neoconstitucionalismo. Madrid, Editorial Trotta.

20. CIANCIARDO Juan, (2004) El principio de razonabilidad. Del debido procesos sustantivo al moderno juicio de proporcionalidad, lera. ed., Buenos Aires.

21. CIANCIARDO Juan, (2004) Modernidad y falacia naturalista Díkaion, Vol 13

22. CIANCIARDO Juan, (2014) Argumentación, principios y razonabilidad. Entre la irracionalidad y la racionalidad, en DIKAION, 23-1

23. CORDERO, Eduardo ( ). Los principios y reglas que estructuran el ordenamiento jurídico chileno, revista IUS ET PRAXIS - año 15 - $\mathrm{n}^{\circ} 2$

24. COMANDUCCI, P. (1998).Principios Jurídicos e Indeterminación del Derecho.Doxa, Italia, Universidad de Génova.

25. CONRRADO,Imitola y ROQUE, Luis(2012).Los Principios en la Contratación Estatal. Bogotá. Grupo Editorial Ibáñez.

26. C., Carlos (2011).Trasparencia y Lucha Contra la Corrupción en la Contratación Estatal, en La Ley 1150 de 2007, una respuesta a la eficacia y trasparencia en la Contratación Estatal La Nueva Contratación Publica en Colombia. Bogotá. Editorial Universidad del Rosario.

27. CHACÓN, Antonio (2013). Celebración de contratos sin cumplimiento de requisitos legales. Bogotá. Primera Edición. Editorial, Ibáñez. 
28. DÍEZ, Luis. (2001). Fundamentos de derecho civil patrimonial, $4^{\mathrm{a}}$ edición, Civitas, citado por SILVA RUIZ, Madrid.

29. DEIK, Carolina, (2014), Guia de Contratación Estatal: Deber de Planeación y Modalidades de Selección, Buenos Aires. Editorial Abeledoperrot.

30. DE LA CALLE LOMBANA. Humberto (1991). Control constitucional. Intervención ante la asamblea nacional constituyente. Bogotá, Ministerio de gobierno.

31. DE VIVIERO ARCINIEGAS, Felipe, (2010).Reforma al régimen de Contratación Estatal. Bermúdez, Martin.Los procesos de selección (75-107). Bogotá. Primera Edición. Universidad de los Andes.

32. DOMÍNGUEZ, Gil Andrés (2008) Neoconstitucionalismo y última palabra, publicado en el La Ley 2008 B, Derecho Constitucional, Doctrinas Esenciales Tomo I

33. DWORKIN, Ronald (1988) El impero de la justicia, Barcelona: Editorial Gedisa.

34. DWORKIN, Ronald (2007). Los Derechos en Serio, España, Editorial Ariel

35. DROMI Roberto, (2010). LicitaciónPública. Buenos Aires, Madrid, México, Editorial Hispania Libros.

36. DUEÑAS RUIZ, Oscar José (2001). Lesiones de Teoría Constitucional. Bogotá, Ediciones Librería del Profesional.

37. ESSER, J. (1961). Principio y Norma en la Elaboración Jurisprudencial del Derecho Privado. Barcelona. Traducción al Español de E ValentiFiol, Bosch.

38. ESTRADA, Sergio (2010). Los Principios Jurídicos en Colombia, Algunas Recomendaciones para su Incorporación. Revista Diálogos de Saberes Mayo de, Bogotá Universidad Libre.

39. EXPOSITO, Juan (2009).Contratación Estatal Estudios Sobre la Reforma al Estatuto Contractual Ley 1150 de 2007. Bogotá. Universidad Externado de Colombia.

40. EXPÓSITO, J. (2013).Serie Derecho Administrativo No. 19 Forma y Contenido del Contrato Estatal. Bogotá. Universidad Externado de Colombia.

41. FANDIÑO, J. (2014). La Contratación Estatal. Bogotá. Editorial,Leyer. 
42. HABERMAS, Jurgen, (2002) Verdad y Justificación, Madrid, Editorial Trotta

43. JIMÉNEZ, William (2008). Entre Reglas y Principios. Misión Jurídica Revista de Derecho y Ciencias Sociales ISSN 1794-600X NUMERO 1enero - diciembre de, Bogotá Universidad Colegio Mayor de Cundinamarca.

44. JOJOA, Bolaños (2012). Los Regímenes Exceptuados en los Contratos Estatales, Bogotá. Editorial Ibáñez.

45. GARCÍA, Claudia y MENDOZA Janne (2009). El Seguro de Cumplimiento y la ContrataciónPublica. Bogotá. Editorial.

46. GARCÍA,Alfonso (1998). La incidencia de la derrotabilidad de los principios iusfundamentales sobre el concepto de derecho. Revista diritto\&questionipubbliche. Universidad de Castilla la Mancha.

47. GARCIA, Franklin (2014).La conciliación Administrativa. Bogotá. Tercera Edición. Editorial Ibáñez.

48. GONZALEZ, Edgar (2010).Serie Derecho Administrativo No 10. El Pliego de Condiciones en la Contratación Estatal. Bogotá. Universidad Externado de Colombia.

49. GIL DOMINQUEZ Andrés (2008). Neoconstitucionalismo y última Palabra. La Ley 2008-B, 985. Buenos Aires, Derechos constitucionales-doctrinas esenciales.

50. GUECHA, Ciro (2010). Contratos Administrativos. Control de legalidad en el Procedimiento Administrativo de Contratación. Bogotá. Segunda Edición. Editorial Ibáñez, Universidad Santo Tomas.

51. HART, Herbert, (1961). El concepto de Derecho, Traduccion de Genaro R. Carrio, Buenos Aires (1998) Abeledo-Perrot.

52. HABERMAS, J. 2003. Acción comunicativa y razón sin trascendencia. Paidós, Barcelona.

53. HINESTROSA, Fernando (2001). 60 años de la Reforma Constitucional de 1936, en Revista Derecho del Estado, Número 1, enero 1997, Bogotá, Universidad Externado de Colombia.

54. LÓPEZ, Osorio, Mendoza, Jiménez, Victoria, Betancourt, Hernández, Mazabel, Carrillo y Oliveros (2010). Hermenéutica y Argumentación Jurídica. Bogotá, Universidad Libre de Colombia. 
55. LÓPEZ, P. (2012).Los Principios y La Interpretación en la Función Judicial, Interpretación y Argumentación Jurídica. Asociación Argentina de Filosofía del Derecho y Sociedad Española de Filosofía Jurídica y Política, Marcial Pons, Buenos Aires, Madrid, Barcelona.

56. MATALLANA, Ernesto (2009). Manual de Contratación de la Administración Pública. Bogotá. Segunda Edición. Editorial, Universidad Externado de Colombia.

57. MARTINEAU,Francois (2009).Argumentación Judicial del Abogado. Barcelona, Editorial: Bosch S.A.

58. MATALLA CAMACHO, Ernesto (2013). Manual de Contratación de la Administración Pública. Bogotá. Tercera Edición, Universidad Externado de Colombia.

59. MARTÍNEZ, Paola (2014). Derecho Procesal Administrativo Análisis Doctrinal de la Ley 1437 de 2011. Bogotá. Editorial, Jurídica Radar Ediciones.

60. MOLANO., Mario (2009).La Nueva Estructuración de los Procesos Selectivos en la Contratación Estatal. Bogotá. Ediciones Nueva Jurídica.

61. MADRID, Mario y MALO Garizabal (1998). Preámbulo. De los principios Fundamentales, de la reforma constitucional. Bogotá, Comisión Colombiana de Juristas.

62. MEJIA, Álvaro, (2014) Nuevo sistema de Compras y Contratos de la Administración Publica. Bogotá. Editorial, Biblioteca Jurídica DIKE.

63. MUNAR,Lucelly y ORTIZ, Luis (2014). Derecho Procesal Administrativo y de lo Contencioso Administrativo. Bogotá. Editorial, Temis Universidad Católica de Colombia.

64. OSA, Jaime. (2009). Derecho Administrativo Sancionador. Bogotá. Editorial Legis.

65. OSPINA, Guillermo. \& Ospina, Eduardo. (2000). Teoría general del contrato y del negocio jurídico. Temis. Bogotá.

66. ORTEGA TORRES, Jorge (2006). La Constitución Política de Colombia. Bogotá. Editorial, TEMIS.

67. ORREGO,Gerardo (2013). La prevalencia de los principios en la contratación estatal, como primer límite al ejercicio de la declaración administrativa de la caducidad del contrato. Revista de derecho Suma Iuris Vol. 1 No. 1 julio a diciembre de 2013, Fundación Universitaria Luis Amigo, Medellín Colombia. 
68. OSPINA M, Jesus Marino.(2010)Celebración y perfeccionamiento del contrato estatal, "Temas en Contratos Estatales" Bogotá, Primera Edición, Biblioteca Jurídica DIKE.

69. PALACIO,Juan (2010). La Contratación de las Entidades Estatales. Bogotá.Sexta Edición. Editorial, Librería Jurídica Sánchez R Ltda.

70. PALACIO,Juan (2014). La Contratación de las Entidades Estatales.Bogotá. Séptima Edición. Editorial, Librería Jurídica Sánchez R Ltda.

71. PINO,Jorge (2005). El Régimen Jurídico de los Contratos Estatales.Bogotá. Primera Edición. Universidad Externado de Colombia.

72. PRIETO, L. (1996). Diez Argumentos a Propósito de Los Principios.

73. PRIETO Sanchis Luis (2003). Justicia constitucional y derechos fundamentales. Madrid, Editorial Trotta.

74. POMBO, Manuel Antonio y GUERRA José Joaquín (1986). Constituciones de Colombia. Bogotá, Biblioteca Banco Popular, Tomo IV.

75. PEREZ LUÑO, Antonio Enrique (1999). Derechos Humanos, Estado de Derecho y Constitución. Madrid, Editorial, Tecnos.

76. RAMÍREZ, S. (2012). Ediciones Nueva Jurídica, Instituto Colombiano de Derecho Disciplinario, La Responsabilidad Disciplinaria Derivada de la Actividad Contractual, Colección Jurídica Disciplinaria, Bogotá. Volumen I, pág. 202.

77. RICO, Puerta (2012). Teoría General y Práctica de la Contratación Estatal. Bogotá. Séptima Edición. Editorial,Leyer.

78. RODRIGUEZ, L. (2005). Derecho Administrativo General y colombiano. Bogotá. Editorial Temis.

79. RODRIGUEZ, L. (2009). El equilibrio Económico en los contratos Administrativos. Bogotá. Editorial Temis.

80. RUIZ, Ramón (1991).La distinción entre reglas y principios y sus implicaciones en la aplicación del derecho. Universidad de Jaen España, URBE et IUS: Newsletter Nro. 20.

81. SÁNCHEZ, E., YATE, D. Y DIAZ, A. (2009). Derecho Disciplinario Parte Especial, Estudio Sistemático de las Faltas Gravísimas. Bogotá. Primera Edición. Ediciones, Nueva Jurídica. 
82. SANTOFIMIO GAMBOA, Jaime Orlando (1980). Tratado de Derecho Administrativo. Bogotá, Editorial, Temis. Tomo I.

83. SANTOFIMIO GAMBOA, Jaime Orlando (1998), Tratado de derecho administrativo, acto administrativo, procedimiento, eficacia y validez, 3 edición, Bogotá, Universidad Externado de Colombia

84. SANTOFIMIO, J. (2002).Delitos de Celebración Indebida de Contratos. Bogotá. Universidad Externado de Colombia.

85. SANTOFIMIO GAMBOA, Jaime Orlando (2007). Tratado de Derecho Administrativo. Bogotá, Editorial, Universidad Externado de Colombia G. Tomo I.

86. SANTOFIMIO GAMBOA, Jaime Orlando (2007). Tratado de Derecho Administrativo. Bogotá, Editorial, Universidad Externado de Colombia G. Tomo II.

87. SANTOFIMIO GAMBOA, Jaime Orlando (2010). Contratación Estatal Legislación. Bogotá, Editorial, Universidad Externado de Colombia.

88. SOTO, Carlos. (2003), La autonomía privada y la buena fe como fundamento de la fuerza obligatoria del contrato.Universitas Ciencias Jurídicas y SocioeconómicasNo.106.

89. SUESCUN, Jorge. (2005). La Aplicación del Postulado de la Autonomía de la Voluntad en la Contratación de las Entidades estatales, en Derecho Privado: Estudios de Derecho Civil y Comercial Contemporáneo, 2da. Edición. Editorial Legis, Bogotá.

90. SUAREZ, Tamayo(2010).Temas en Contratos Estatales, Fundamentos Constitucionales, Principios y reglas de Interpretación de la contratación Estatal en Colombia. Editorial. Biblioteca Jurídica Dike, Medellín Colombia.

91. SOBREVILlA, D. (1996).El Modelo Jurídico de Reglas, Principios y Procedimientos de Robert Alexy. Perú. Universidad de San Marcos y Universidad de Lima.

92. SOLARTE, Felipe. (2010).Contratos Estatales Atipicos. Bogotá. Segunda Edición. Ediciones Nueva Jurídica.

93. SUAREZ, Gonzalo (2014). Estudios de Derecho Contractual Público. Bogotá. Primera Edición. Legis Editores S.A.

94. SUAREZ, Gonzalo(2009).La Nueva Contratación Pública en Colombia. Bogotá. Editorial Legis. 
95. SUAREZ, David (2010).Fundamentos Constitucionales, Principios y Reglas de Interpretación de la Contratación Estatal en Colombia; Temas en Contratos Estatales. Bogotá. Editorial, Biblioteca Jurídica Dike.

96. WALTERWilburg (1950), Desarrollo de un sistema móvil dela ley civil, Graz. El desarrollo de un sistema flexible en el área del derecho privado, Edición de Viena 2000

97. WOLF Cristopher (1991). La Transformación de la interpretación constitucional. Madrid, Editorial Civitas.

98. YONG, Samuel, (2013). El contrato Estatal en el Contexto de la Nueva Legislación. Bogotá Tercera Edición. Grupo Editorial Ibáñez.

99. ZAGREBLESKY, Gustavo (1995).El Derecho dúctil. Ley, derechos, justicia. Madrid. trad. de M. Gascón, Trotta.

100.PRINCIPIOS Y REGLAS: Una aproximación desde los criterios de distinción. Boletín Mexicano de Derecho Comparado, nueva serie, año XXXVI, núm. 108, septiembre-diciembre de 2003, pp. 891-906.

101.CORTE CONSTITUCIONAL, Sentencia C-083, de 1995, M.P. Carlos Gaviria Díaz.

102.CORTE CONSTITUCIONAL, Sentencia C-574 de 1992, MP.Ciro Angarita Barón.

103.CORTE CONSTITUCIONAL, Sentencia T-005 de 1995. M.P: Dr. Eduardo Cifuentes Muñoz.

104.CORTE CONSTITUCIONAL, Sentencia C-067 de 2003. M.P.: Dr. Marco Gerardo Monroy Cabra.

105.CORTE CONSTITUCIONAL, Sentencia C-225 de mayo 18 de 1995 MP.Valencia Restrepo.

106.CORTE CONSTITUCIONAL, Sentencia T- 406 de 1992. MP. Ciro Angarita Baron.

107.CORTE CONSTITUCIONAL, Sentencia C-818 de 2005. MP. Rodrigo Escobar Gil.

108.CORTE CONSTITUCIONAL, Sentencia C- 128 de 18 de febrero de 2003. MP. Álvaro Tafur Galvis.

109.CORTE CONSTITUCIONAL, Sentencia-949 de 2001. MP. Clara Inés Vargas. 
110.CORTE CONSTITUCIONAL, Sentencia-400 de 1999. MP. Vladimiro Naranjo Mesa.

111.CORTE CONSTITUCIONAL, Sentencia C-128 de 2003, M.P. Álvaro Tafur Galvis.

112.CONSEJO DE ESTADO, Sentencia del 3 de diciembre de 2007, expedientes acumulados: 25206, 25409, 24524, 27834, 25410, 26105, 28244, 31447, C.P.: Ruth Stella Correa Palacio

113.CONSEJO DE ESTADO, 14 de abril de 2005. Expediente 25094, C.P. German Rodríguez Villamizar.

114.CONSEJO DE ESTADO, Sala de lo Contencioso Administrativo. Sección Tercera. Sentencia de Junio 4 de 2008. M. P. Myriam Guerrero de Escobar. Exp. 17783.

115.CONSEJO DE ESTADO, Sala de lo Contencioso Administrativo, Sección Tercera, de 12 de diciembre de 2001, Exp. 16.886.

116.CONSEJO DE ESTADO, Sentencia del 7 de octubre de 2009. Expediente 11001032600020100003800 (39.040), C.P. Ruth Estela Correa.

117.CONSEJO DE ESTADO, Sentencia del 20 de mayo de 2010. Expediente 11001-0306-000-2010-00034-00 (1992). C.P. Enrique José Arboleda.

118.CONSEJO DE ESTADO, Sección Tercera, sentencia de junio de 4 de 2008. MP. Miriam Gurrero de Escobar. Exp. 17783.

119.CONSEJO DE ESTADO, Sección Tercera, sentencia de junio de 4 de 2008. MP. Miriam Gurrero de Escobar. Exp. 17783.

120.CONSEJO DE ESTADO, Sección Tercera, sentencia del 29 de julio de 2013, MP. Danilo Rojas Betancourth. Radicación: 25000-23-26-000-1995-01712-01.

121.CONSEJO DE ESTADO, Sala de Consulta y Servicio civil, sentencia del 20 de mayo de 2010, MP. Enrique José Arboleda, Radicación: 11001-03-06-000-201000034-00(1992.

122.CONSEJO DE ESTADO, Sala de Contencioso Administrativo, sentencia del 12 de diciembre de 2001, MP. Enrique José Arboleda, Exp. 16.886.

123.CONSEJO DE ESTADO, Sección Tercera, sentencia del 18 de septiembre de 2010, MP. Mauricio Fajardo Gómez, Radicación: 25000-23-26-000-1994-0007101(14390). 
124.CONSEJO DE ESTADO, 3 de diciembre de 2007. Expediente 31447, C.P. Ruth Estela Correa.

125.PROCURADURÍA GENERAL DE LA NACIÓN, Código Disciplinario Único, 2011.

126.PROCURADURÍA GENERAL DE LA NACIÓN,fallo del 20 de noviembre de 2006, expediente 038-5816.

127.GACETA DEL CONGRESO N 75 del 23 de septiembre de 1993. 